\title{
10. SITE 543: OCEANIC REFERENCE SITE EAST OF THE BARBADOS RIDGE COMPLEX1
}

\author{
Shipboard Scientific Party ${ }^{2,3}$
}

\section{HOLE 543}

Date occupied: 28 February 1981

Date departed: 3 March 1981

Time on hole: 3 days, $14 \mathrm{hr}$.

Position: $15^{\circ} 42.74^{\prime} ; 58^{\circ} 39.22^{\prime}$

Water depth (sea level; corrected m, echo-sounding): 5633

Water depth (rig floor; corrected m, echo-sounding): 5643

Bottom felt (m, drill pipe): 5637.0

Penetration (m): 332

Number of cores: 34

Total length of core section (m): 324.0

Total core recovered $(\mathrm{m}): 228.4$

Core recovery $(\%)$ : 79.5

Oldest sediment cored:

Depth sub-bottom (m): 332

Nature: Claystone

Age: early Eocene

Measured velocity $(\mathrm{km} / \mathrm{s}): 2.453$ (543-34,CC-hard claystone)

Basement: Not reached

\section{HOLE 543A}

Date occupied: 3 March 1981

Date departed: 9 March 1981

Time on hole: 6 days, $1 \mathrm{hr}$.

Position: $15^{\circ} 42.74^{\prime} ; 58^{\circ} 39.22^{\prime}$

Water depth (sea level; corrected $\mathrm{m}$, echo-sounding): 5633.0

Water depth (rig floor; corrected m, echo-sounding): 5643.0

\footnotetext{
${ }^{1}$ Biju-Duval, B., Moore, J. C., et al., Init. Repts DSDP, 78A: Washington (U.S. Govt. Printing Office)

2 Bernard Biju-Duval (Co-Chief Scientist), Institut Français du Pétrole, 92505 Ruei Malmaison, France (present address: Centre National pour l'Exploitation des Octans, $66 \mathrm{Av}$ enue d'Iéna, 75116 Paris, France); J. Casey Moore (Co-Chief Scientist), Earth Sciences and Marine Studies, University of California at Santa Cruz, Santa Cruz, California; James A Bergen, Department of Geology, Florida State University, Tallahassee, Florida; Grant Blackinton, Hawaii Institute of Geophysics, University of Hawaii at Manoa, Honolulu, Hawaii George E. Claypool, Branch of Oil and Gas Resources, U.S. Geological Survey, Denver Federal Station, Denver, Colorado; Glenn Foss, Deep Sea Drilling Project, Scripps Institution of Oceanography, La Jolla, California; Rodolfo T. Guerra, Exploration Services Center, Mobi Exploration and Producing Services, Dallas, Texas; Christoph $\mathrm{H}$. J. Hemleben, Institut und Museum für Geologie und Pallontologie, Universiat Tubingen, D-7400 Tubingen 10, Museum fir Geologie und Palch eral Republic of Germany, Michael S. Marlow, U.S. Geological Survey, Menlo Park, California; James H. Natland, Deep Sea Drilling Project, Scripps Institution of Oceanography, La Jolla, California; Carol J. Pudsey, Department of Geology, University of Leicester, Leicester, United Kingdom; G. W. Renz, Deep Sea Drilling Project, Scripps Institution of Oceanography, La Jolla, California (present address: 5260 Angeles Crest, La Canada, California); Marc Tardy, Départment de Sciences de la Terre, Université de Savoie, BP 1104, Chambéry, France; Douglas Wilson, Hawaii Institute of Geophysics, University of Hawail at Manoa, Honolulu Hawaii (present address: Department of Geophysics, Stanford University, Stanford, Calif nia); Audey Wright, Earth Sciences and Marine Studies, University of Califor at Sas nia); Arey Wright, Earth Sciences and Marine Studies, University of California at Sant Cruz, Santa Cruz, California (present address: Deep Sea Drilling Project, Scripps Institution of Oceanography, La Jolla, California).

${ }_{3}$ With a contribution from Daniel Davis, Department of Earth and Planetary Sciences, Massachusetts Institute of Technology, Cambridge, Massachusetts.
}

Bottom felt (m, drill pipe): 5637.0

Penetration (m): 455.0

Number of cores: 16

Total length of core section $(\mathrm{m}): \mathbf{1 4 2 . 5}$

Total core recovered $(\mathrm{m}): \mathbf{6 9 . 4}$

Core recovery $(\%): 48.7$

Oldest sediment cored:

Depth sub-bottom (m): 409

Nature: Ferruginous, calcareous claystone

Age: Campanian-Maestrichtian

Measured velocity $(\mathrm{km} / \mathrm{s}): 1.671(543 \mathrm{~A}-10-1,28-32 \mathrm{~cm})$

Basement:

Depth sub-bottom (m): 411.0 (top); 455 (bottom of hole)

Nature: Basalt

Velocity range $(\mathrm{km} / \mathrm{s}): 4.910$ to 5.621

Principal results: At Site 543 we penetrated a $411-\mathrm{m}$ sequence of hemipelagic and pelagic sediments and $44 \mathrm{~m}$ of basaltic pillow lavas. The Recent sediments consist of ashy mud to a depth of $10 \mathrm{~m}$. The subjacent sediments to $70.5 \mathrm{~m}$ are Pleistocene to upper Pliocene ashy nannofossil mud, transitional to a unit of lower Pliocene to lower Miocene mud and ashy mud that extends to $176 \mathrm{~m}$ sub-bottom. Radiolarian clay, initially with local ash layers, and subsequently with manganese stains, occurs from 176 to $322 \mathrm{~m}$ sub-bottom spanning the lower Miocene to Oligocene, respectively. Zeolitic clay-claystone is present from 322 to $379 \mathrm{~m}$ sub-bottom and overlies a basal calcareous, ferruginous, Maestrichtian to Campanian claystone that contacts basalt at $411 \mathrm{~m}$. Plagioclase and plagioclase-olivine phyric pillow basalts extend to a total sub-bottom depth of $455 \mathrm{~m}$.

Overall, the lithology at Site 543 records the birth and evolution of an open-ocean crustal sequence with its progressive approach to the Lesser Antilles volcanic arc. The upper $200 \mathrm{~m}$ of early Miocene and younger rocks are lithologically and paleontologically identical to the sequences cored at Sites 541 and 542, arguing for the oceanic derivation and hence offscraping of the latter at the deformation front of the Barbados Ridge complex. A marked increase in density and shear strength between about 180 and $200 \mathrm{~m}$ sub-bottom lies just under the seaward extension of a reflector separating the apparently offscraped and subducted units to the west. The observed changes in physical properties seemingly predict development of a décollement at 180 to $200 \mathrm{~m}$ sub-bottom as inferred from seismic data.

A downhole seismometer with temperature and tilt recorders was emplaced in the basaltic basement at Site 543 . The instrument remained in the hole while a seismic refraction experiment was conducted. Malfunctioning of the seismometer necessitated retrieval of the downhole instrument and prevented deployment of the long-term recording package on the seafloor.

\section{BACKGROUND AND OBJECTIVES}

Site 543 lies on seismic line A1C about $22 \mathrm{~km}$ northnortheast of Sites 541 and 542 and $3.5 \mathrm{~km}$ seaward of the deformation front of the Barbados Ridge complex (Fig. 1-3). The substantial northward offset of Site 543 relative to Sites 541 and 542 was required in order to minimize the sediment penetration and therefore ensure reaching the ocean crust. Site 543 is on the northern 


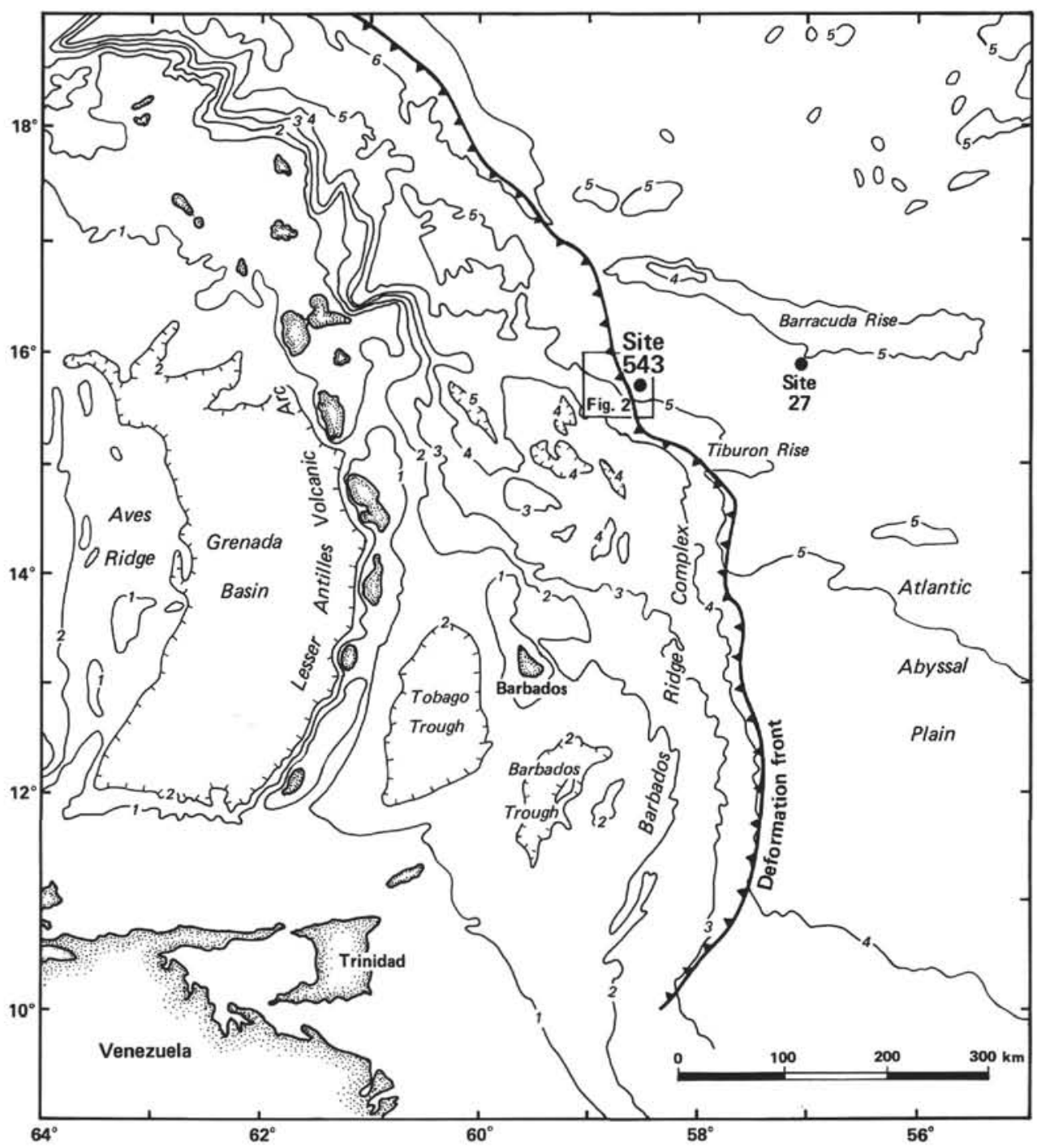

Figure 1. Regional location map. (Note position of deformation front defining eastward boundary of Barbados Ridge and Tiburon Rise underthrusting deformation front near Site 543. Contour intervals are in kilometers.)

flank of the Tiburon Rise and therefore penetrated a depositional sequence similar to that lying on the ocean plate seaward of Sites 541 and 542. Moreover, the principal acoustic reflectors noted at Sites 541 and 542 can be traced to Site 543 via the site survey seismic grid. Thus the demonstrable continuity in acoustic stratigraphy throughout the Leg $78 \mathrm{~A}$ area permits Site 543 to be used as an oceanic reference site for Sites 541 and 542, despite their lateral offsets.

Both the Tiburon and Barracuda rises constitute prominent highs emerging from the Atlantic abyssal plain and presently intersecting the deformation front of the Barbados Ridge complex (Fig. 1). The sediment thickness near Site 543 is about 400 to $500 \mathrm{~m}$ and locally reaches at least $1100 \mathrm{~m}$ on the ocean plate in the Leg $78 \mathrm{~A}$ area (Ngokwey et al., this volume). To the south on the Atlantic abyssal plain, sediments gradually attain a thickness of more than $4 \mathrm{~km}$, suggesting derivation and lateral transport from the south (Biju-Duval et al., 1978;
Mascle et al., in press). The damming effects of the Tiburon and Barracuda rises also contribute to the northward thinning of sediment on the Atlantic abyssal plain.

The principal goal of Site 543 was definition of an oceanic reference section that would allow multiple comparisons to the sequences cored landward of the deformation front at Sites 541 and 542. Specific objectives of drilling at Site 543 were: (1) to test by lithologic and paleontologic criteria whether the sections cored at Sites 541 and 542 are of ocean-plate origin and thereby offscraped from the Tiburon Rise area; (2) to provide a physical-property profile through the undisturbed oceanplate section and thereby a basis for measuring the tectonic consolidation of any offscraped rocks of similar lithology; (3) to date and establish physical and lithologic contrasts across the seaward projection of the reflector separating the apparently off-scraped and underthrust sequences landward of the deformation front (here we hoped to determine the physical basis for their apparent 


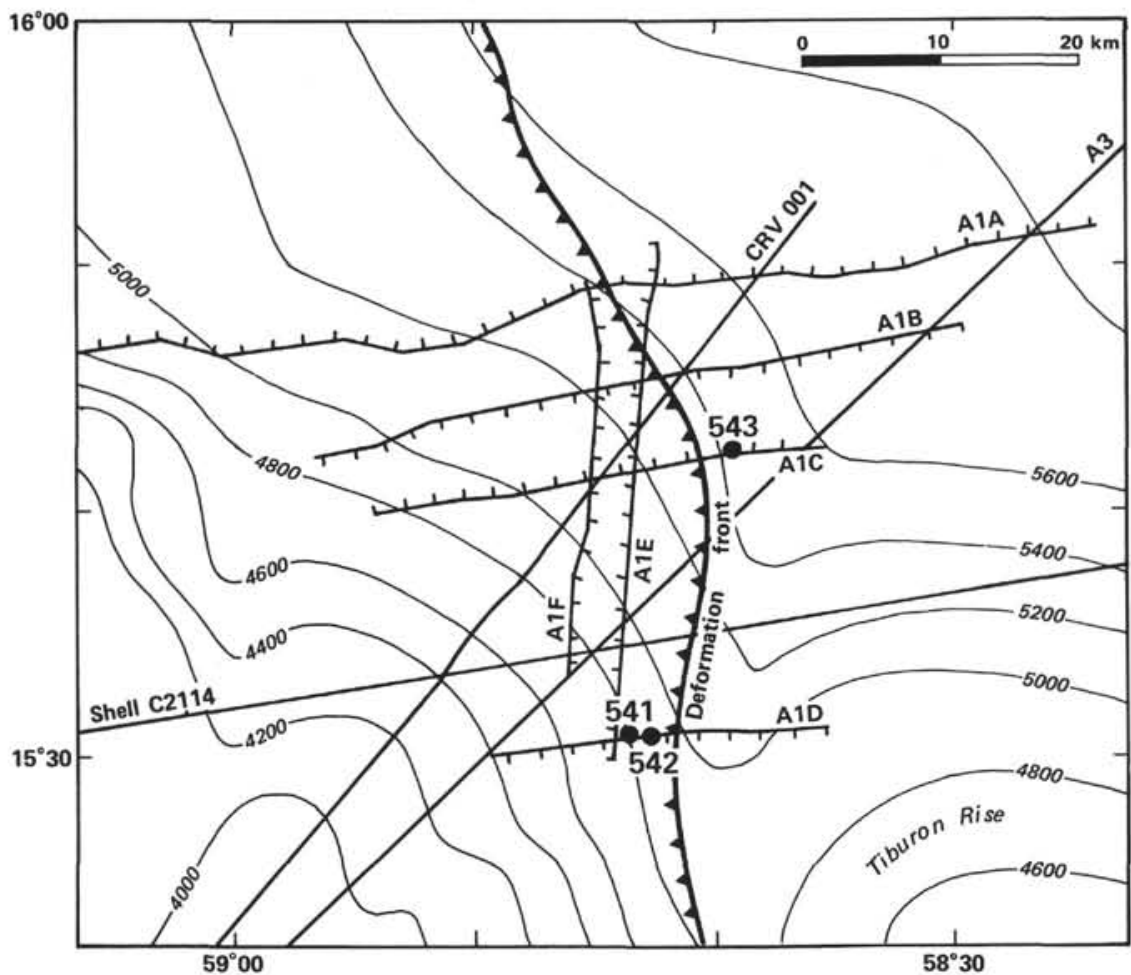

Figure 2. Detailed site location map (box, Fig. 1). (Note position of deformation front and location of seismic reflection lines used for site survey. Bathymetry is in meters. Lines A1A to A1D from IFP/CNEXO survey [from Ngokwey et al., this volume].)

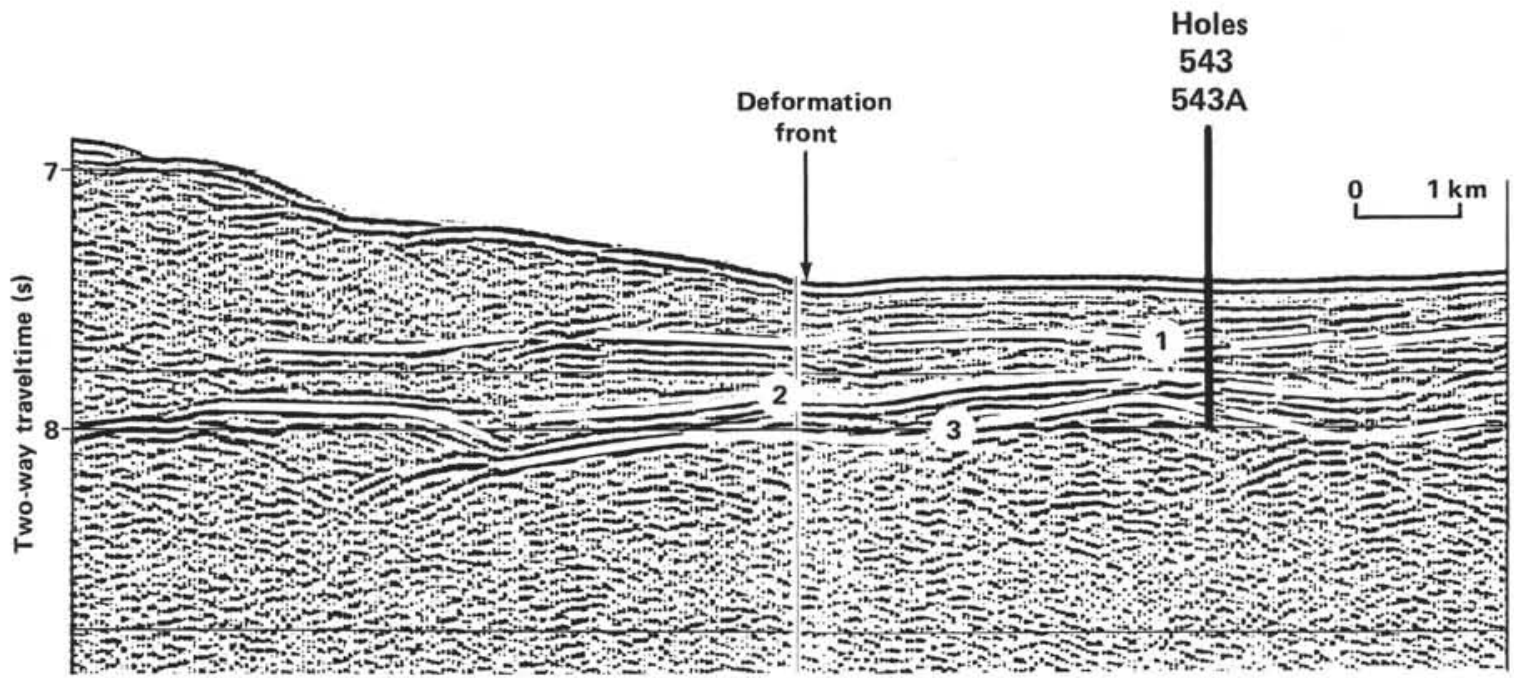

Figure 3. Seismic reflection line A1C. (From Ngokwey et al., this volume.) Reflector 1 is equivalent to the boundary between a discontinuously reflective (deformed) unit and an acoustically layered unit at Sites 541 and 542. Reflector 2 separates seismic units of tabular (above) and irregular (below) thicknesses. Reflector 3 is top of oceanic crust.

décollement surface); (4) to sample the section underthrust deeply beneath the Barbados Ridge complex (because we failed to penetrate this underthrust sequence at either Site 541 or Site 542 , sampling it at Site 543 was crucial); and (5) to date the ocean crust and emplace a downhole seismometer in the basement.

\section{OPERATIONS}

\section{Hole 543}

Site 543 is located about $12 \mathrm{mi}$. north-northeast of Site 542 and seaward of the toe of the trench slope. Its primary purpose was to provide an undisturbed refer- 
ence section for comparison with the disturbed and accreted sediments cored on the slope. The inability to penetrate to basement at Sites 541 and 542 dictated that Site 543 would also be the location for the downhole seismometer implantation.

The move and site approach consumed only $2 \mathrm{hr}$, and a positioning beacon was launched at $0450 \mathrm{hr} ., 28$ February. The seismic gear was retrieved and on-site stationing began while the beacon was still falling. The beacon signal, which had never been strong, faded completely after $1 \mathrm{hr}$., and a second beacon (of alternate frequency) was dropped to replace it.

The pipe trip was extended by about $4.25 \mathrm{hr}$. to assemble a new bottom-hole assembly (BHA) to replace the one lost in Hole 542B. Several satellite navigation fixes were received during the trip, and a positioning offset of $910 \mathrm{~m}$ to the south was made to move the vessel onto seismic profile.

Using the corrected precision depth recorder (PDR) reading of $5653 \mathrm{~m}$ as a guide, an initial seafloor punch core was taken by lowering the bit to $5655.5 \mathrm{~m}$. Signs of "taking weight" were first noted on the rig weight indicator at about $5649 \mathrm{~m}$. On recovery the inner core barrel was filled to its top, which had penetrated to $5646 \mathrm{~m}$. Water depth was therefore estimated at $5645 \mathrm{~m}$. Continuous coring then continued to $324 \mathrm{~m}$ sub-bottom without significant difficulty. Coring and recovery data are given in Table 1.

As Core 34 was being recovered, the inner barrel suddenly became jammed in the drill pipe about $1500 \mathrm{~m}$ above the bit. The overshot shear pin failed during attempts to free the inner barrel and the sand line was retrieved. A second inner barrel was pumped down to jar the first barrel loose, but without success. A second wireline recovery attempt also failed to move the stuck core barrel. It was then necessary to pull about $4200 \mathrm{~m}$ of drill pipe to recover the core. The barrel was found to be jammed in place by a steel ball that had fallen down the pipe from the latch of the adjustable line wiper.

\section{Hole 543A}

With the drill string cleared of obstructions, it was tripped back to the seafloor. A second attempt to recover a "mud-line" punch core and to verify water depth was then made by lowering the bit to $5647 \mathrm{~m}$. On recovery, sediment was again found packed to the top of the barrel, and water depth was revised to $5637 \mathrm{~m}$. Again, coring and recovery data are presented in Table 1.

The hole was drilled, without coring, to 332 meters sub-bottom. Considerable hole problems occurred below about $260 \mathrm{~m}$. Torquing and vertical sticking of the pipe, along with annular plugging, nearly forced us to abandon the hole at one point. The problems were attributed to adherence of sticky clay to the drill collars. Fortunately firmer sediments were reached near the end of the drilled interval and an improvement in hole conditions was noted after "working" the pipe and circulating mud slugs. The "wash" core barrel was recovered, and continuous coring commenced. Core recovery for the lower sediment section was consistently below normal for unknown reasons. Basaltic basement was reached
Table 1. Coring summary, Site 543.

\begin{tabular}{|c|c|c|c|c|c|c|c|}
\hline $\begin{array}{l}\text { Core } \\
\text { no. }\end{array}$ & $\begin{array}{c}\text { Date } \\
\text { (1981) }\end{array}$ & Time & $\begin{array}{l}\text { Depth from } \\
\text { drill floor } \\
\text { (m) } \\
\text { top bottom }\end{array}$ & $\begin{array}{l}\text { Depth below } \\
\text { seafloor } \\
\text { (m) } \\
\text { top bottom }\end{array}$ & $\begin{array}{l}\text { Length } \\
\text { cored } \\
(\mathrm{m})\end{array}$ & $\begin{array}{l}\text { Length } \\
\text { recovered } \\
\text { (m) }\end{array}$ & $\begin{array}{c}\text { Amount } \\
\text { recovered } \\
(\%)\end{array}$ \\
\hline \multicolumn{8}{|c|}{ Hole 543} \\
\hline 1 & Feb. 28 & 2150 & $5635.0-5645.5$ & $0-10.5$ & 10.5 & 9.12 & 90 \\
\hline 2 & Feb. 28 & 2342 & $5645.5-5655.0$ & $10.5-20.0$ & 9.5 & 7.86 & 83 \\
\hline 3 & Mar. 1 & 0148 & $5655.0-5664.5$ & $20.0-29.5$ & 9.5 & 9.73 & 102 \\
\hline 4 & Mar. 1 & 0334 & $5664.5-5674.0$ & $29.5-39.0$ & 9.5 & 9.71 & 102 \\
\hline 5 & Mar. 1 & 0524 & $5674.0-5683.5$ & $39.0-48.5$ & 9.5 & 6.51 & 69 \\
\hline 6 & Mar. 1 & 0706 & $5683.5-5693.0$ & $48.5-58.0$ & 9.5 & 9.49 & 100 \\
\hline 7 & Mar. 1 & 0850 & $5693.0-5702.5$ & $58.0-67.5$ & 9.5 & 5.20 & 55 \\
\hline 8 & Mar. 1 & 1041 & $5702.5-5712.0$ & $67.5-77.0$ & 9.5 & 7.43 & 78 \\
\hline 9 & Mar. 1 & 1225 & $5712.0-5721.5$ & $77.0-86.5$ & 9.5 & 9.60 & 101 \\
\hline 10 & Mar. 1 & 1410 & $5721.5-5731.0$ & $86.5-96.0$ & 9.5 & 6.62 & 70 \\
\hline 11 & Mar. 1 & 1600 & $5731.0-5740.5$ & $96.0-105.5$ & 9.5 & 4.47 & 47 \\
\hline 12 & Mar. 1 & 1741 & $5740.5-5750.0$ & $105.5-115.0$ & 9.5 & 9.78 & 103 \\
\hline 13 & Mar. 1 & 1925 & $5750.0-5759.5$ & $115.0-124.5$ & 9.5 & 9.72 & 102 \\
\hline 14 & Mar. 1 & 2120 & $5759.5-5769.0$ & $124.5-134.0$ & 9.5 & 8.12 & 85 \\
\hline 15 & Mar. 1 & 2307 & $5769.0-5778.5$ & $134.0-143.5$ & 9.5 & 3.59 & 39 \\
\hline 16 & Mar. 2 & 0109 & $5778.5-5788.0$ & $143.5-153.0$ & 9.5 & 6.83 & 61 \\
\hline 17 & Mar. 2 & 0258 & $5788.5-5797.5$ & $153.0-162.5$ & 9.5 & 6.81 & 72 \\
\hline 18 & Mar. 2 & 0448 & $5797.5-5807.0$ & $162.5-172.0$ & 9.5 & 9.03 & 95 \\
\hline 19 & Mar. 2 & 0630 & $5807.0-5816.5$ & $172.0-181.5$ & 9.5 & 8.54 & 90 \\
\hline 20 & Mar. 2 & 0816 & $5816.5-5826.0$ & $181.5-191.0$ & 9.5 & 5.98 & 63 \\
\hline 21 & Mar. 2 & 1010 & $5826.0-5835.5$ & $191.0-200.5$ & 9.5 & 0.0 & 0 \\
\hline 22 & Mar. 2 & 1155 & $5835.5-5845.0$ & $200.5-210.0$ & 9.5 & Th. & 0 \\
\hline 23 & Mar. 2 & 1350 & $5845.0-5854.5$ & $210.0-219.5$ & 9.5 & 3.61 & 38 \\
\hline 24 & Mar. 2 & 1610 & $5854.5-5864.0$ & $219.5-229.0$ & 9.5 & 6.74 & 71 \\
\hline 25 & Mar. 2 & 1815 & $5864.0-5873.5$ & $229.0-238.5$ & 9.5 & 3.51 & 37 \\
\hline 26 & Mar. 2 & 2030 & $5873.5-5883.0$ & $238.5-248.0$ & 9.5 & 9.02 & 95 \\
\hline 27 & Mar. 2 & 2325 & $5883.0-5892.5$ & $248.0-257.5$ & 9.5 & 8.87 & 93 \\
\hline 28 & Mar. 3 & 0150 & $5892.5-5902.0$ & $257.5-267.0$ & 9.5 & 7.91 & 83 \\
\hline 29 & Mar. 3 & 0340 & $5902.0-5911.5$ & $267.0-276.5$ & 9.5 & 9.82 & 103 \\
\hline 30 & Mar. 3 & 0530 & $5911.5-5921.0$ & $276.5-286.0$ & 9.5 & 8.96 & 94 \\
\hline 31 & Mar. 3 & 0715 & $5921.0-5930.5$ & $286.0-295.5$ & 9.5 & 1.88 & 20 \\
\hline 32 & Mar. 3 & 0945 & $5930.5-5940.0$ & 295.5-305.0 & 9.5 & 7.12 & 73 \\
\hline 33 & Mar. 3 & 1230 & $5940.0-5949.0$ & $305.0-314.5$ & 9.5 & 4.02 & 44 \\
\hline 34 & Mar. 3 & 2358 & $5949.5-5959.0$ & $314.5-324.0$ & 9.5 & 2.80 & 29 \\
\hline Total & & & & & 324.0 & 228.4 & 79.5 \\
\hline \multicolumn{8}{|l|}{$\begin{array}{l}\text { Hole } \\
543 \mathrm{~A}\end{array}$} \\
\hline 1 & Mar. 4 & 0827 & $5627.0-5637.0$ & $0-10.0$ & 10.0 & 7.87 & 79 \\
\hline нía & Mar. 4 & 1808 & $5637.0-5959.0$ & $10.0-332.0$ & Washed & 5.21 & - \\
\hline 2 & Mar. 4 & 2050 & $5659.0-5968.5$ & $332.0-341.5$ & 9.5 & 2.44 & 26 \\
\hline 3 & Mar. 4 & 2245 & 5968.5-5978.0 & $341.5-351.0$ & 9.5 & 2.92 & 31 \\
\hline 4 & Mar. 5 & 0150 & $5978.0-5987.5$ & $351.0-360.5$ & 9.5 & 3.98 & 42 \\
\hline 5 & Mar. 5 & 0307 & $5987.5-5997.0$ & $360.5-370.0$ & 9.5 & 4.21 & 44 \\
\hline 6 & Mar. 5 & 0510 & $5997.0-6006.5$ & $370.0-379.5$ & 9.5 & 1.25 & 13 \\
\hline 7 & Mar. 5 & 0745 & $6006.5-6016.0$ & $379.5-389.0$ & 9.5 & 4.91 & 52 \\
\hline 8 & Mar. 5 & 1045 & $6016.0-6025.5$ & $389.0-398.5$ & 9.5 & 1.11 & 12 \\
\hline 9 & Mar. 5 & 1315 & $6025.5-6035.0$ & $398.5-408.0$ & 9.5 & 0.97 & 11 \\
\hline 10 & Mar. 5 & 1805 & $6035.0-6044.5$ & $408.0-417.5$ & 9.5 & 3.12 & 32 \\
\hline 11 & Mar. 5 & 2105 & $6044.5-6047.0$ & $417.5-420.0$ & 2.5 & 2.27 & 91 \\
\hline 12 & Mar. 6 & 0145 & $6047.0-6054.0$ & $420.0-427.0$ & 7.0 & 4.17 & 60 \\
\hline 13 & Mar. 6 & 0710 & $6054.0-6063.0$ & $427.0-436.0$ & 9.0 & 8.53 & 95 \\
\hline 14 & Mar. 6 & 1011 & $6063.0-6065.0$ & $436.0-438.0$ & 2.0 & 0.85 & 43 \\
\hline 15 & Mar. 6 & 1724 & $6065.0-6072.0$ & $438.0-445.0$ & 7.0 & 6.61 & 94 \\
\hline 16 & Mar. 7 & 0102 & $6072.0-6082.0$ & $445.0-455.0$ & 10.0 & 9.0 & 90 \\
\hline Total & & & & & 142.5 & 69.4 & 48.7 \\
\hline
\end{tabular}

a Core 543A-H1 is a wash core that recovered material from 10 to $332 \mathrm{~m}$ sub-bottom with the core barrel in place; percent recovery data are not given for this core.

at $411 \mathrm{~m}$ sub-bottom. Good hole conditions and $81 \%$ core recovery prevailed in the basement rocks, with penetration at a slow $2 \mathrm{~m} / \mathrm{hr}$. Coring operations were terminated at $455 \mathrm{~m}$ sub-bottom due to time and scheduling considerations.

The core bit and associated components were released by activating the mechanical bit release with a wire-line shifting tool. The open-ended drill string was then pulled to $280 \mathrm{~m}$ sub-bottom for logging. Because of the soft nature of the sediment, the pipe was left fairly deep in the hole to avoid the bridging and plugging tendencies of soft clay that have often frustrated logging attempts.

The temperature-density-gamma ray sonde was rigged and run down the pipe to $5600 \mathrm{~m}$, the starting point for the temperature log. When only about $20 \mathrm{~m}$ of temperature log had been recorded-and before seafloor depth had been reached-a downhole electrical problem devel- 
oped that caused the loss of temperature logging capability. The equipment was switched to the density-caliper-gamma ray mode, but the problems remained. The logging tool was recovered and the trouble was traced to seawater in the DSDP-furnished sinker bar. A backup sinker bar was installed and a second attempt was made. An open-hole bridge was encountered just $2 \mathrm{~m}$ below the end of the pipe. The sonde was worked through this and two other obstructions as temperature was logged to $375 \mathrm{~m}$ sub-bottom. A more substantial bridge at this point could not be penetrated after several attempts. A static temperature measurement was then recorded and the logging mode was switched to the density mode to $\log$ up to the pipe. It was then found that the density log detectors had apparently been damaged by the rough treatment the tool had received in getting through obstructions. The logging sonde became stuck upon reentering the drill string and could be moved neither up nor down. During attempts to dislodge it, the tool suddenly came free while under considerable pull. It was subsequently found that the caliper backup arm had been broken off and left in the hole. The caliper and gamma ray curves were good, however, and verified that the borehole was badly eroded, with an average diameter of 13 to 14 in. Density or sonic logs would therefore have been of little value in the sediment section. Because insufficient operating time remained to clean the hole and log the basement interval, the logging cable was then reheaded for the attachment of the Hawaii Institute of Geophysics (HIG) ocean sub-bottom seismometer (OSS) package.

While the reheading and final instrument package tests were in progress, the power sub was picked up and the hole was cleaned to $4 \mathrm{~m}$ above total depth. To avoid plugging the end of the pipe, high pump rates were used to clean the hole, and downward progress was stopped at the first sign of contact on the weight indicator. Two joints of drill pipe were then set back, leaving just $22 \mathrm{~m}$ of open hole.

At just past midnight on 8 March, the seismometer was started down the pipe. Unfortunately, the instrument met an obstruction at the end of the drill string and would not pass into open hole. It was concluded that, despite precautions, the end of the bit release top connector had become plugged with sediment and/or drill cuttings and that pump circulation was through the "windows" in the side of the top connector. After a few minutes of unsuccessful effort to get the instrument out of the pipe, it was recovered for an attempt to unplug the pipe. A specially weighted junk inner core barrel section was assembled and pumped down the pipe at maximum pump rate. Pump pressure was abnormally high and no change in pressure was noted after an adequate interval of pumping. With a great deal of anxiety, we again lowered the seismometer package through the pipe on the logging cable. At $0905 \mathrm{hr}$., the instrument passed out of the pipe. It was then successfully emplaced in the open basalt hole and a series of tests were run.

With the seismometer finally in place, the logging cable was clamped off at the top of the drill pipe and cut. A special cable slip-pulling neck assembly was attached to the end of the in-hole portion of the cable. This was latched up to an overshot-swivel assembly on the sand line, the weight of the cable was taken by the sand line, and the clamp was removed. The logging sheaves were then rigged down, and the slow process of stripping the pipe out of the hole begun. The pipe trip proceeded smoothly, however, and over $6 \mathrm{~km}$ of pipe were pulled past the cable in $16 \mathrm{hr}$.

The cable in the hole was then respliced to the remainder on the winch by means of a "torpedo" connection. Following tests of the downhole instrument package, the cable on the winch was slowly payed out while the ship was offset a total of $3.6 \mathrm{~km}$ from the hole. As this exceeded the maximum offset capability of the positioning system, it was necessary to drop a new acoustic beacon for station-keeping at the new location.

The accompanying vessel, North Star, had emplaced an array of five ocean bottom seismometers (OBS) several miles across and centered on Site 543. Test charges were then fired to test the response of the OSS and communications between the two vessels in preparation for refraction profiling. At this point, the downhole seismometer data were found to be garbled and not usable. The data from one shooting line was taped in the hope that some data could be retrieved.

The Challenger was then slowly moved back to the drill site as the logging cable was retrieved. The OSS was pulled from the hole without undue difficulty, despite the inability to retract the caliper arm. The instrument was on deck at $1945 \mathrm{hr}$., 9 March, and the vessel got underway at $2006 \mathrm{hr}$.

\section{Site 543 to San Juan}

The Challenger steamed about $20 \mathrm{mi}$. north to rendezvous with the North Star, which was engaged in refraction shooting for the OBS array. Following transfer of personnel back to the North Star, the profiling gear was streamed and the Challenger began postsite profiling that passed over Site 543. At $0056 \mathrm{hr}$., $10 \mathrm{March}$, the survey was completed and course was set for the return to San Juan.

\section{SEDIMENT LITHOLOGY}

\section{Lithostratigraphy}

Site 543, the oceanic reference site, was drilled in 5627 $\mathrm{m}$ water depth, $3.5 \mathrm{~km}$ east of the toe of the accretionary prism. Two holes were drilled at Site 543: Hole 543 was continuously cored for $324 \mathrm{~m}$ before a core barrel jammed in the drill pipe and the hole had to be abandoned. Hole 543A was cored continuously below $332 \mathrm{~m}$ and penetrated $44 \mathrm{~m}$ of basaltic basement. The first sediment continuously cored at Hole 543A (Core 2) is just beneath the deepest sediment cored at Hole 543 (Core 34). The sediment recovery from Holes 543 and 543A was sufficient to permit good lithostratigraphic definition of the oceanic reference site sediments.

Based on macroscopic core descriptions, smear slide analyses, and calcium carbonate bomb data, the sequence of sediments and rock units drilled at Site 543 can be divided into seven lithologic units (Fig. 4). A summary of these units is shown in Table 2. Downhole percentages 


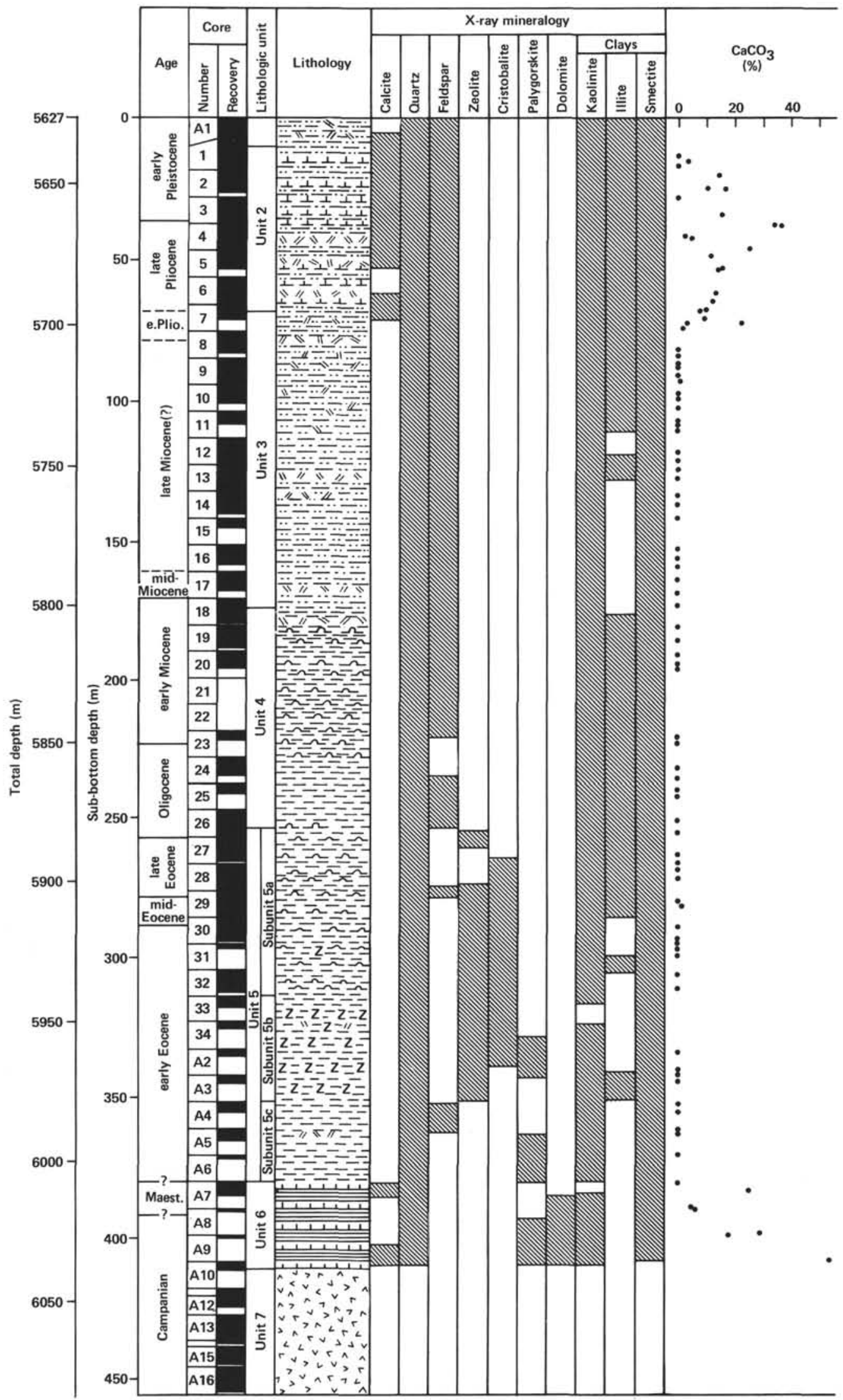

Figure 4. Summary lithology, sediment composition, structure, physical properties, and seismic stratigraphy, Site 543. (In X-Ray Mineralogy column blackened areas simply show presence.) 


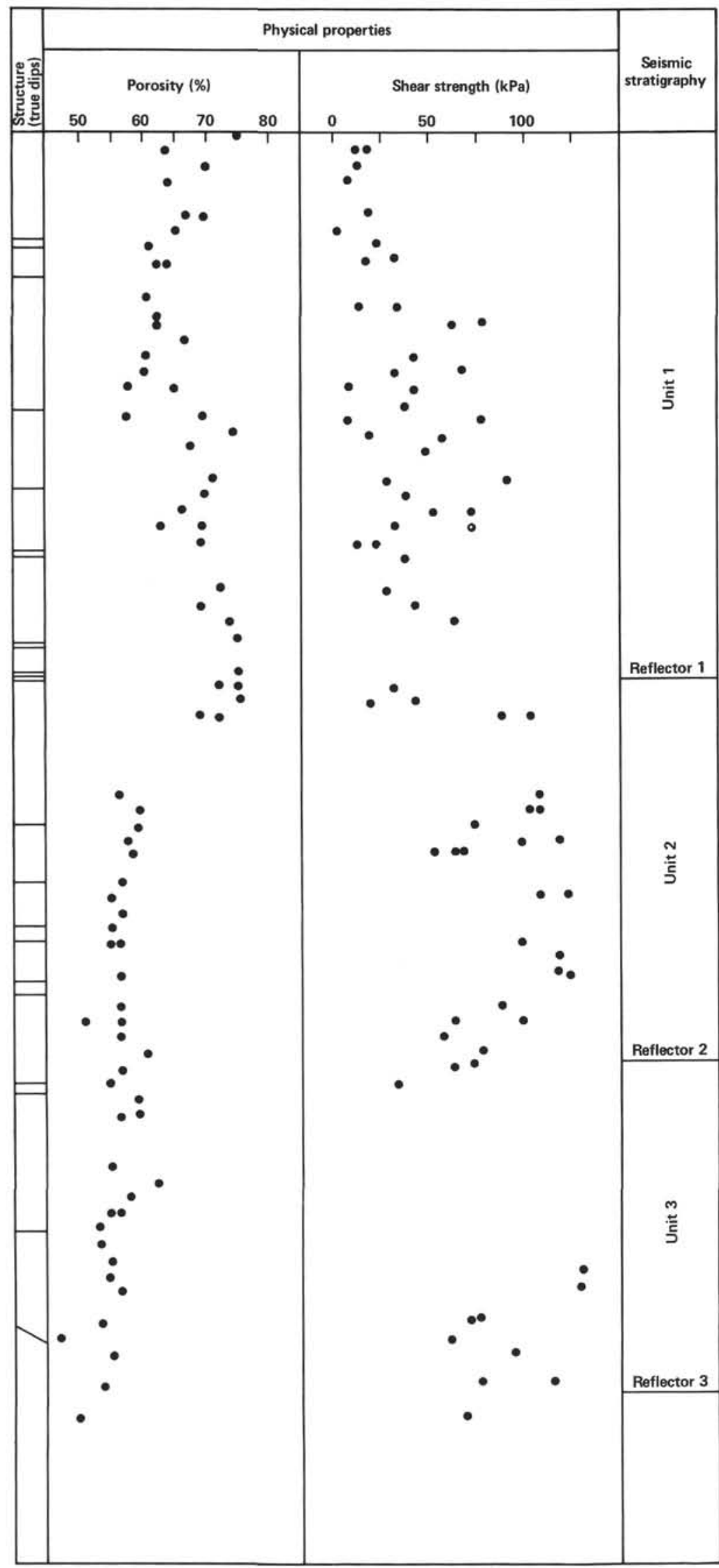

Figure 4. (Continued)

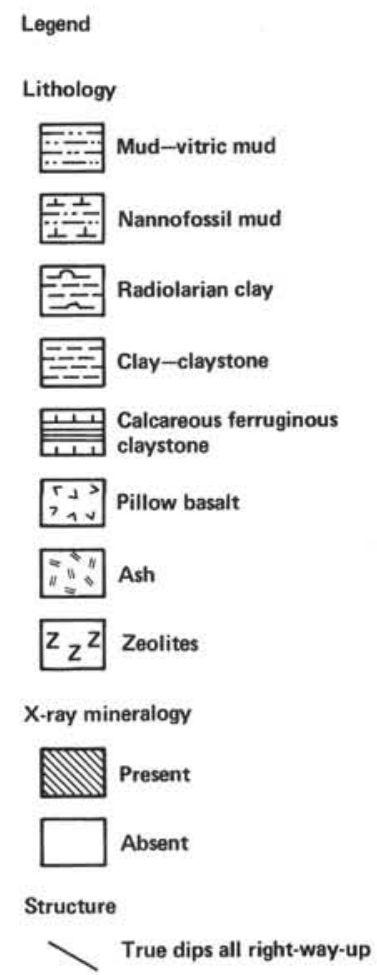


Table 2. Lithologic units, Site 543.

\begin{tabular}{|c|c|c|c|c|c|c|}
\hline \multirow[b]{2}{*}{$\begin{array}{l}\text { Unit, } \\
\text { subunit }\end{array}$} & \multicolumn{2}{|c|}{ Hole 543} & \multicolumn{2}{|c|}{ Hole $543 \mathrm{~A}$} & \multirow[b]{2}{*}{ Dominant lithology } & \multirow[b]{2}{*}{ Age } \\
\hline & $\begin{array}{l}\text { Sample } \\
\text { (core-section, } \\
\text { cm level) }\end{array}$ & $\begin{array}{l}\text { Sub-bottom } \\
\text { depth } \\
\text { (m) }\end{array}$ & $\begin{array}{l}\text { Sample } \\
\text { (core-section, } \\
\text { cm level) }\end{array}$ & $\begin{array}{l}\text { Sub-bottom } \\
\text { depth } \\
\text { (m) }\end{array}$ & & \\
\hline 1 & - & - & 1 & $0-8$ & Ashy mud & Quaternary \\
\hline 2 & 1 to $7-2,100$ & $8-68.5$ & - & - & $\begin{array}{l}\text { Ashy nannofossil mud } \\
\text { and vitric mud with } \\
\text { ash layers }\end{array}$ & early Pleistocene-late Pliocene \\
\hline 3 & $7-2,{ }_{50} 100$ to $18-3$, & $68.5-174.0$ & - & - & $\begin{array}{l}\text { Mud and vitric mud } \\
\text { with ash layers }\end{array}$ & early Pliocene-early Miocene(?) \\
\hline 4 & $\begin{array}{l}18-3,50 \text { to } 26-5 \text {. } \\
100\end{array}$ & $174.0-253.0$ & - & - & $\begin{array}{l}\text { Radiolarian clay with } \\
\text { ashy layers }\end{array}$ & early Miocene-Oligocene \\
\hline 5a & $26-5,100$ to 32 & $253.0-313.0$ & - & - & $\begin{array}{l}\text { Mn-stained radiolarian } \\
\text { clay }\end{array}$ & Oligocene-middle late Eocene \\
\hline $5 \mathrm{~b}$ & 33 to 34 & $313.0-322.0$ & 2 to 3 & $322.0-351.0$ & $\begin{array}{l}\text { Zeolitic clay-claystone } \\
\text { and clay-claystone }\end{array}$ & Eocene \\
\hline $5 \mathrm{c}$ & - & - & 4 to 6 & $351.0-379.5$ & Claystone & Eocene \\
\hline 6 & - & - & 7 to $10-2,100$ & $379.5-411.0$ & $\begin{array}{l}\text { Calcareous ferruginous } \\
\text { claystone }\end{array}$ & $\begin{array}{l}\text { Cretaceous (early Maestrichtian } \\
\text { early Campanian) }\end{array}$ \\
\hline 7 & - & - & $10-2,100$ to 16 & $411.0-455.0$ & Pillow basalts & Cretaceous \\
\hline
\end{tabular}

Note: - indicates no data.

of calcium carbonate at Site 543 were determined with the shipboard carbonate bomb (Fig. 4).

Lithologic Unit 1 is an 8-m-thick, Quaternary ashy mud drilled in the mud-line core (Core 1) of Hole 543A that overlies and is younger than the first sediment drilled at Hole 543 . It is primarily brown (10YR $5 / 3)$ with dark grayish brown (10YR 4/2) to light brownish gray (10R $6 / 2$ ) ashy layers and patches, vague streaking, and slight color variations throughout. The entire unit has been intensely deformed and swirled by drilling.

Lithologic Unit 2 is a 60 -m-thick, lower Pleistocene to upper Pliocene, brown (10YR 5/3) ashy nannofossil mud with interbedded grayish brown (10YR $5 / 2)$ vitric muds and gray to dark gray (5Y 5/1-5Y 3/1) ash layers. The color of this unit gradually changes downhole to olive gray (5Y 5/2) and gray (5Y 5/1-5Y 6/1). It has been moderately to intensely deformed by drilling throughout.

Lithologic Unit 3 is a $105-\mathrm{m}$-thick, lower Pliocene to lower Miocene, mottled and bioturbated mud and vitric mud with ash layers. It is differentiated from the overlying unit by an absence of calcareous components, indicating deposition below the CCD. The clay is primarily olive gray (5Y 5/2) with some brown (10YR 5/3) to grayish brown (10YR 5/2) layers in the top $35 \mathrm{~m}$, gradually changing to greenish gray (5GY 5/2) below Core 12 . The ash layers and patches range from medium dark gray (N4) to very dark gray (10YR 3/1) to brownish black (5YR 2/1) to black and often have distinctive greenish gray $(5 \mathrm{G} 6 / 1)$ alteration halos around them. The unit has been intensely deformed by drilling that has greatly disturbed original bedding and burrows.

Lithologic Unit 4 is a 79-m-thick, bioturbated, lower Miocene to Oligocene radiolarian clay with ashy patches and ash layers. It is differentiated from the overlying unit by the presence of more than $10 \%$ radiolarians. The greenish gray (5GY 5/1) with olive $(5 Y 5 / 3)$ and olive gray $(5 \mathrm{Y} 5 / 2)$ mottles in the upper $10 \mathrm{~m}$, gradually changing to primarily olive gray ( 5 Y $5 / 2-5 Y 6 / 2$ ) and olive $(5 Y 5 / 3)$, with greenish gray (5GY 5/1) layers below Core 19 , Section 2 . The ash beds vary from 1 to $10 \mathrm{~cm}$ thick, range from dark gray to grayish brown (10YR 4/ 1-10YR 4/2) to black (N2.5), and are frequently associated with pale blue green (5BG 7/2) to greenish gray (5G
6/1) alteration halos. Bioturbation is faint except near the upper contacts of the ash layers. Though the unit has been moderately deformed by drilling, horizontal layering is observed in Core 25. A white 5-mm-thick layer of rhodochrosite is found in Core 24, Section 4.

Lithologic Unit 5 is a 124-m-thick, Oligocene to lower Eocene pelagic unit that is divisible into three subunits $(5 \mathrm{a}, 5 \mathrm{~b}$, and $5 \mathrm{c})$ on the basis of macroscopic core descriptions, smear slide analyses, and shipboard XRD results (see the section on X-Ray Diffraction, this chapter).

Subunit $5 a$ is a 60 -m-thick Oligocene(?) to middle upper Eocene, burrowed and mottled, manganese-stained radiolarian clay. It is differentiated from the overlying unit by the presence of abundant manganese-oxide stains. The clay is light yellowish brown (10YR 6/4) to very pale brown (10YR 6/3-10YR 7/3) and contains abundant gray $(10 \mathrm{YR} 6 / 1)$ to dark grayish brown $(10 \mathrm{YR} 4 / 2)$ to black (20YR 2.5/1) manganese-oxide stains. Distinctive parallel laminations are observed in Core 32, Section 1.

Subunit $5 b$ is a 38-m-thick, Eocene interbedded zeolitic clay-claystone and clay-claystone unit. It is differentiated from the overlying subunit by a scarcity (less than $10 \%$ ) or absence of radiolarians, rather than by the presence of zeolites in the sediment (zeolites first appear in XRD analyses of the sediments in the radiolarian clay of Core 30, Hole 543; see the X-Ray Diffraction section, this chapter). The zeolitic clays or claystones in this unit are light yellowish brown (10YR 6/4) to pale brown (10YR 6/3); the interbedded clays or claystones are yellowish red (5YR 4/6-5YR 6/6). Rare blebs and approximately 1 -cm-thick layers of greenish gray (5GY 6/1-5GY 7/1) altered ash are found throughout the unit. Dark gray (N4) to very dark grayish brown manganese-oxide stains occur in Core 3, Hole 543A. The entire unit has been intensely deformed by drilling, consisting of pancake-shaped coherent lumps ("biscuits") separated by thin shear zones ("rotational shear zones"), which are an artifact of drilling and are spaced every 2 to $5 \mathrm{~cm}$ down the core. Laminations and burrows are found in the firm, coherent "biscuits."

Subunit $5 c$ is a 28 -m-thick, Eocene, predominantly reddish brown (2.5YR 4/4-2.5YR 4/5) burrowed claystone. It is differentiated from the overlying subunit by 
an absence of zeolites (see the section on X-Ray Diffraction). The upper portion of the subunit (Core 4 , Hole 543A) contains some yellowish brown (10YR 5/4) to brown (7.5YR 5/4) layers and has some dark grayish brown (10YR 4/2) to very dark grayish brown (10YR $3 / 2$ ) manganese-oxide stains. It has been very deformed by drilling, consisting of coherent "biscuits" embedded in a highly brecciated, sheared, and slickensided matrix of the same material.

Lithologic Unit 6 is a 31.5-m-thick, lower Maestrichtian to lower Campanian, horizontally laminated, bioturbated, calcareous ferruginous claystone deposited on top of Cretaceous basement (see Hemleben and Troester, this volume). It is differentiated from the overlying sediment by the presence of calcareous and ferruginous components. The unit is variegated dark brown (7.5YR $3 / 2$ ) to reddish brown (5YR 4/3-5YR 4/4) and contains yellowish red (5YR 5/4) nannofossil-rich layers. Cores 7,8 , and 9 (Hole 543A) contain authigenic dolomite.

Lithologic Unit 7 consists of Cretaceous basement pillow basalts (see the section on Basalts, this chapter).

All of the sediments cored at Site 543 were deposited below the lysocline (see the section on Paleoenvironments, this chapter). The vast majority of sediments accumulated by pelagic-hemipelgic settling in quiet, deep water on top of Cretaceous basement (Lithologic Unit 7). Evidence for deposition of some material by gravity flows was found in a 4-cm-thick, foraminifer-rich layer in Core 3, Section 5, Hole 543. Ash beds found in Lithologic Units 1 to 4 do not appear to have been redeposited as turbidites, but probably settled to the seafloor following volcanic eruptions on the Lesser Antilles island arc. The relatively great amounts of ash particles in Lithologic Units 1 to 4 indicate a substantial input of volcanic material from the Lesser Antilles island arc as the Atlantic crust moved toward the arc.

\section{Bioturbation}

Bioturbation is prevalent in the Site 543 cores, but there are fewer recognizable forms than at either Sites 541 or 542 . The uppermost $70 \mathrm{~m}$ of sediment are too badly swirled by drilling to detect any original sedimentary features. Slight burrow mottling first appears in Core 8 (543) and becomes a little more pronounced in Core 12. Core 18 contains burrowed ash beds and all further cores down to 29 are burrow mottled, but without recognizable ichnogenera. Core 30 is mottled at the top and base only. Core 31 contains rather large "mottles" 1 to $3 \mathrm{~cm}$ across instead of the normal burrows less than $1 \mathrm{~cm}$ in diameter. Some of these may be diagenetic nodules rather than burrows. Core 32 contains sporadic burrows of Planolites type. The lowest two, Cores 33 and 34 at Hole 543, contain drilling biscuits in a deformed matrix. The biscuits preserve lamination and bioturbation. The sedimentation rate was high enough that burrowing animals did not have time to rework the sediment completely.

In Hole $543 \mathrm{~A}$, Cores 2 to 4 are not conspicuously burrowed. Together with the lack of arenaceous benthic foraminifers, this characteristic may indicate anoxic or at least oxygen-poor bottom conditions. Cores 5 and 6 are burrow mottled, and the variegated ferruginous clays of Cores 7 to 9 exhibit spectacular burrowing (Fig. 5). Abundant Planolites, a few Zoophycus, tiny Chondrites, and a pelleted oblique burrow (?Teichichnus) were identified in Core 7. Core 9 contains laminae of lighter and darker brown sediment, and the tops and bases of the laminae are burrowed on a minute scale.

There are two possible reasons for the preservation of lamination in these basal ferruginous sediments deposited near the ridge crest: (1) the sedimentation rate was too high to allow complete reworking; (2) the environment may have been fairly rugged, with the water full of noxious exhalations and ferruginous manganiferous brines and vapors (c.f., Galapagos Rift), and not many animals lived there.

\section{X-Ray Mineralogy}

Fifty-six samples were analyzed from this site, using the same method as described for Site 541. The minerals identified include quartz, alkali feldspar, plagioclase, calcite, zeolites (clinoptilolite and ?heulandite), cristobalite, palygorskite, kaolinite, illite, smectite and dolomite, plus traces of apatite and hematite. A thin white vein in Sample 543-24-4, $92 \mathrm{~cm}$ was identified as rhodochrosite. Results are summarized in Figure 4 and described in more detail in Pudsey (this volume).

Quartz occurs throughout. Feldspars occur from 0 to $250 \mathrm{~m}$ sub-bottom, and in general the peak for alkali feldspar is higher than that for plagioclase. Calcite is present in the Pleistocene and Pliocene muds above 75 $\mathrm{m}$ sub-bottom, and sporadically in the Eocene and Cretaceous below $380 \mathrm{~m}$. Zeolites are present from 250 to $350 \mathrm{~m}$ and cristobalite from 280 to $320 \mathrm{~m}$. Palygorskite occurs from $335 \mathrm{~m}$ to the base of the sediments, but its peak height fluctuates wildly and it is not present in all samples in this interval. Dolomite occurs only in Cores $543 \mathrm{~A}-7,-8$ and $-9(385-410 \mathrm{~m})$, but is an important constituent of Core 9. Of the nonfibrous clay minerals, kaolinite is present throughout, but its peak height is relatively low from 100 to $200 \mathrm{~m}$. Illite is an important constituent only from 0 to $100 \mathrm{~m}$ and is absent from 135 to $170 \mathrm{~m}$ and below $355 \mathrm{~m}$; smectite is most abundant from 100 to 200 meters, and it decreases noticeably in the lowest $70 \mathrm{~m}$ of sediment.

In the manganiferous Lithologic Subunit 5a, black layers contain much more clay and less quartz than orange layers. Manganese oxides are presumably amorphous, because they do not give a peak on the diffractograms.

\section{Volcanic Ash}

Core disturbance was extreme throughout most of the upper $150 \mathrm{~m}$ of the sediment section (Cores 543-1 to -13 , and 543A-1, covering part of the upper Miocene, the Pliocene, and the Quaternary), which made ash beds difficult to identify and sample. Fortunately, the corresponding interval was much less disturbed at Site 541.

Despite the disturbance, ashy intervals were prominent in many of the upper 14 cores of Hole 543. These are sufficiently disturbed that they have been somewhat mixed with mud, hence they are described as ashy mud, 


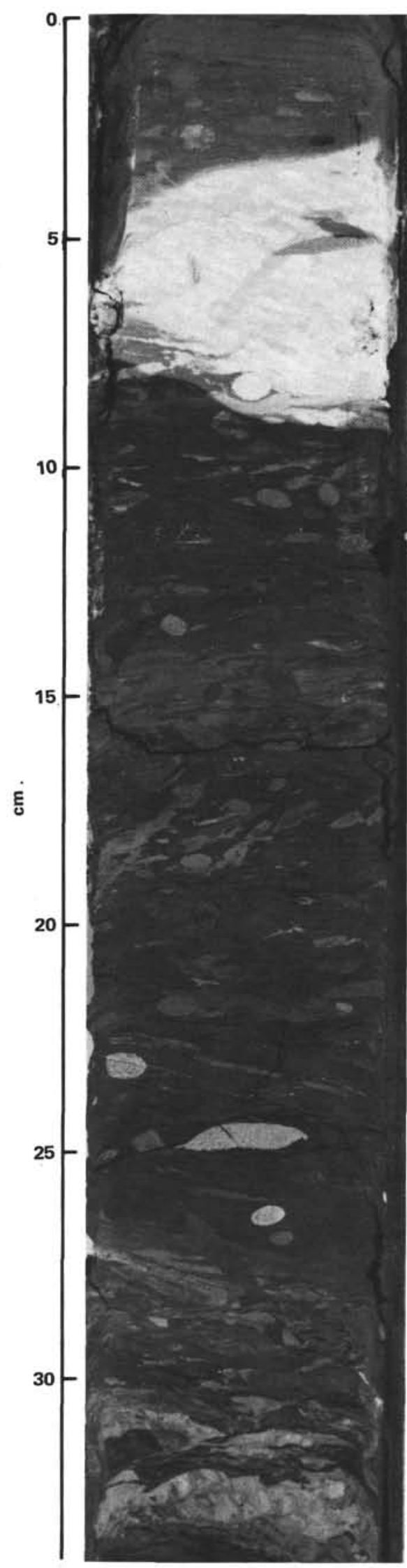

Figure 5. Bioturbated ferruginous clay, Sample $543 \mathrm{~A}-7-3,0-34 \mathrm{~cm}$. (Planolites burrows are filled with lighter material than the surrounding mud.) for the most part, on the core barrel sheets. In a few intervals, there are relatively undisturbed major ash beds up to $5 \mathrm{~cm}$ thick that must correlate with those found at Sites 541 and 542, although the disturbance may make precise correlation nearly impossible.

The principal addition to the ash record that Hole 543 provides is documentation of a significant pulse of explosive volcanism on the Lesser Antilles arc in the early and early middle Miocene (Cores 17-20). Below these cores, there are only scattered and very minor ash occurrences, mostly completely altered to clays. There is one ash deposit in the Oligocene (Core 27). There are none in the middle and upper Eocene. The lower Eocene has 10 thin wisps of altered ash beds that may correspond to the oldest volcanism known from highly altered and restricted outcroppings in the limestone Caribbees. Site 543 was quite a bit further from the arc in the early Eocene than it is now, hence no comparison of the volume of explosive volcanism between the Eocene and modern Lesser Antilles arc is possible with these cores.

The Lesser Antilles arc thus has had three periods of major explosive volcanic activity, corresponding to the early Miocene, early Pliocene, and Quaternary ash beds recovered by drilling at Sites 541,542 , and 543 , as well as in surface piston cores. This finding is a significant improvement in resolution of ash chronology compared with the sketchy data available from the islands. These topics are discussed further by Natland (this volume).

\section{STRUCTURAL GEOLOGY AND DRILLING DEFORMATION}

Most, if not all, of the small-scale structures we observed in cores from Site 543 can be interpreted as drilling-induced. However, there is an apparent correlation between material response and sediment composition that may be a clue to how this stratigraphic section would behave if it were deformed in situ.

Numerous horizontal layers were observed in Cores 543-1 through - 31 and in Cores 543A-2 and -3. The base of an ash layer in Section 543A-4-1 at $62 \mathrm{~cm}$ dips $5^{\circ}$. Burrow-mottled layering in Sample 543A-7-2, 80-130 cm dips up to $30^{\circ}$ in biscuits but varies in magnitude and sense from biscuit to biscuit, partly due to rotation along horizontal drilling fractures. However, some of the dip is probably primary and may reflect deposition on irregular basement topography or faulting near the ridge crest in newly formed basement.

Cores 543-1 to -13 display swirling patterns that are typically produced by drilling in the shallowest, least consolidated sediments. In parts of Cores 543-14 and -16 we noticed firm, coherent chunks of mud separated by softer, more highly deformed mud. Most of Cores 543-17 to -19 and Sections 1 and 2 of Core 543-20 consist of these firm chunks and soft "matrix." Some coherent chunks, when broken open, showed slickensided, polished curviplanar surfaces spaced $<1 \mathrm{~cm}$ apart. Soft portions between chunks have polished surfaces spaced $>1 \mathrm{~cm}$, and locally they have been churned into a hash of small irregular chips averaging a few millimeters in length. The overall alternation of coherent pieces and softer matrix is reminiscent of sections in which ordi- 
nary drilling biscuits are separated by rotational disc fractures induced by drilling. Randomly oriented, polished surfaces spaced between about $1 \mathrm{~mm}$ and $1 \mathrm{~cm}$ were also noted in some cores from Sites 541 and 542 (see Sites 541 and 542 reports, this volume), but they occur in firm, sticky mud and clearly predate drilling disc fractures. In Core 543-23 we again noted swirling.

Sediments in Core 543-26 through part of Core 54332 are manganese-stained pelagic clays that are locally rich in radiolarians. A dip-slip fault dipping $40^{\circ}$, with steps on the polished surface suggesting normal faulting, occurs in Section 5 of Core 29. The first development of well-defined disc fractures and biscuits roughly coincides with the lithologic change from clay to pelagic clay in Core 26. In Hole 543A, Cores 2 through 7 contain pelagic clays devoid of radiolarians. These sediments occur in variably sized, firm, relatively undeformed chunks and lumps, separated and locally surrounded by coherent, highly deformed mud. Some chunks contain polished surfaces spaced $>1 \mathrm{~cm}$, but many bear no signs of internal deformation. The deformed zones between these biscuits range from $2 \mathrm{~mm}$ to at least $20 \mathrm{~cm}$ in thickness. As freshly cut surfaces of cores dry out, tiny hairline cracks form and reflect an internal fabric defined by subparallel polished surfaces spaced about 1 $\mathrm{mm}$ apart. This crude scaly foliation is easily visible when samples of deformed mud are broken apart. In thin, well-defined zones between biscuits, the minicracks (and foliation) are horizontal, but in thicker zones they have variable orientations. Some deformed zones also display wispy and contorted patches of mud that are colored differently from their more voluminous host. Compared with the scaly clays occurring in the bottom few cores at Site 541, the foliation in the deformed zones in Cores 2 through 7 of Hole 543A is less penetrative and less strongly oriented. In addition, these zones in Hole 543A are still sticky and coherent, rather than flaky.

The change from well-defined biscuits separated by thin disc fractures to chunks separated by wider zones of deformed mud coincides approximately with the transitions above and below the radiolarian pelagic clay to pelagic clays at Site 543. This coincidence suggests that deformational response may depend partly on sediment composition. The deformed zones in Cores 543-14 to 20 and 543A-2 to 7 are probably due to drilling rather than in situ deformation. In these cores, we can generally see a complete range in thickness of deformed zones. The thinnest are clearly rotational shear fractures, separating well-formed biscuits; thicker zones $(<1 \mathrm{~cm})$ are identical in their fabric and composition. The material constituting the thickest zones is very similar to deformed sediment in drilling laminations. It is possible, but unlikely that some of this sheared material in the thickest zones formed in situ. Even if all of the deformation in Cores 543-14 to -20 and Cores 543A-2 to -7 can be ascribed to drilling, it is clear that these clay-rich parts of the sedimentary section are weaker and more easily deformed than the radiolarian mudstone, which we obtained in Cores 543-21 to -32, and are thus more likely to serve as horizons of natural décollement. Notably the upper boundary of the radiolarian mudstone coincides approximately with Reflector 1 , which apparently represents a décollement surface separating offscraped and subducted deposits landward of the deformation front.

\section{PORE FLUID CHEMISTRY}

Nine samples were taken for interstitial water geochemistry at Site 543, six from Hole 543, and three from Hole 543A. The data are listed, plotted versus depth, and summarized in Gieskes et al. (this volume). Prominent features of the data are an initial drop in $\mathrm{pH}$ from 0 to $273 \mathrm{~m}$ sub-bottom, then an increase below that to just above basalt, steady decrease of $\mathrm{Ca}^{2+}$ with depth, and an initial decline of $\mathrm{Mg}^{2+}$ to about $150 \mathrm{~m}$, then a slight increase and leveling off between $250 \mathrm{~m}$ to the top of basalts at $408 \mathrm{~m}$. The excess $\mathrm{Mg}^{2+}$ may be reflected in the lowermost sediments by an abundance of palygorskite and the occurrence of dolomite (Pudsey, this volume). The causes for these variations are discussed elsewhere (Gieskes et al., this volume), but migration of fluids similar to those below $350 \mathrm{~m}$ along the shear zone at Sites 541 and 542 could cause the perturbations in $\mathrm{Mg}^{2+}$ abundances observed at those sites.

\section{ORGANIC GEOCHEMISTRY}

Organic carbon content in Site 543 sediments decreases regularly with depth, as was the case for Sites 541 and 542 sediments. $C_{1}$ to $C_{6}$ hydrocarbons are just detectable at 100 to 400 standard gas volumes per $10^{9}$ volumes of sediment. A minor show of nonhydrocarbon gas was confirmed at a depth of about $245 \mathrm{~m}$ in Hole 543. A similar observation at a depth of about $240 \mathrm{~m}$ in Hole 541 was discounted and attributed to core disturbance and air contamination. Subsequent shore-based analyses of this gas (Claypool, this volume) show nitrogen and argon contents in excess of atmospheric content. The origin of this minor nitrogen gas show is unknown at this time.

\section{BIOSTRATIGRAPHY}

A biostratigraphic summary for all microfossil groups examined on board ship is given in Figure 6. The biostratigraphy described here is based on shipboard investigations. For more refined discussions of nannofossils and radiolarians see Bergen (this volume) and Renz (this volume), respectively.

\section{Nannofossils}

\section{Hole 543}

Samples from Cores 1 through 8, Section 1 contain nannofossil assemblages as old as early Pliocene. The preservation in these samples is noticeably worse than in samples of equivalent age from Sites 541 and 542 .

Cores 1 through 3 are zoned as early Pleistocene Pseudoemiliania lacunosa is found in all samples from these cores in which nannofossils occur. The presence of $C y$ clococcolithina macintyrei in Samples 543-1-1, 60-61 $\mathrm{cm}$ to $543-3-2,62-63 \mathrm{~cm}$ place this interval in the Cyclococcolithina macintyrei Zone of Gartner (1977). No Gephyrocapsa are useful in age determinations. 


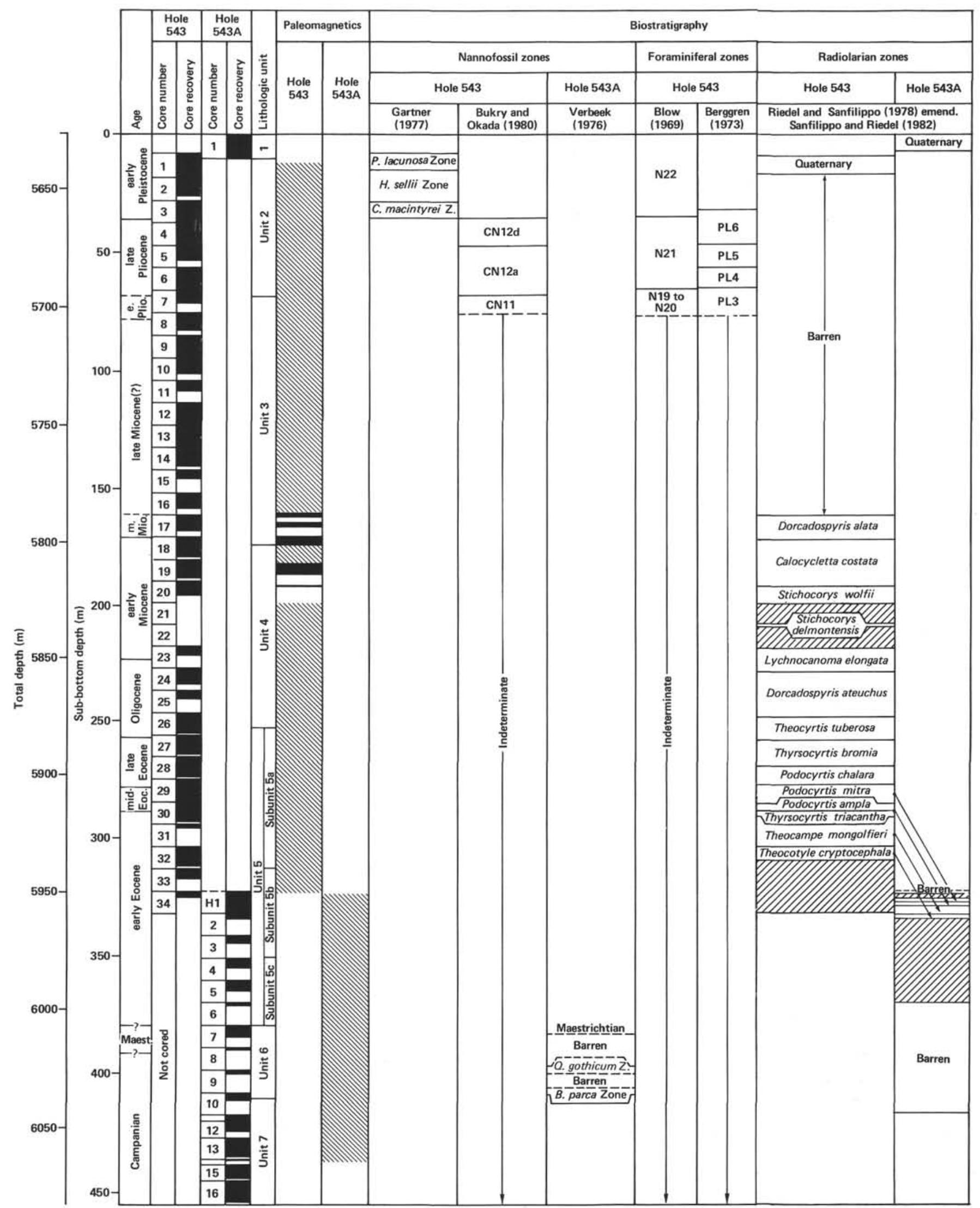

Figure 6. Summary biostratigraphy and magnetostratigraphy, Site 543. (Polarity normal intervals are black, polarity reversed intervals are white, and polarity uncertain intervals [or intervals with no data] are diagonally striped.) 
Cores 4 through 7, Section 2 are late Pliocene. Discoaster tamalis, D. surculus, and D. pentaradiatus have their last occurrences in Sample 543-5-2, 100-101 cm. Therefore, a hiatus exists between that sample and Sample 543-5-1, 100-101 cm. Samples 543-5-2, 100-101 cm to 543-7-2, 55-56 cm are placed in the Discoaster tamalis Subzone (CN12a). Core 4 through Sample 543-5-1, $100-101 \mathrm{~cm}$ are assigned to the Calcidiscus macintyrei Subzone (CN12d). The Discoaster surculus and Discoaster pentaradiatus Subzones $(\mathrm{CN} 12 \mathrm{~b}, \mathrm{c})$ are not recognized in this hole.

Samples 543-7-3, 55-56 cm through 543-8-1, 65-66 cm are placed in the Reticulofenestra pseudoumbilica Zone (CN11), based on the extinctions of Amaurolithus tricorniculatus and $R$. pseudoumbilica. Sphenolithus neoabies, whose extinction is used in addition to R. pseudoumbilica, is last seen in Sample 543-7-2, 55-56 cm. $S$. abies becomes extinct in this same sample.

This hole is barren below Sample 543-8-1, 65-66 cm.

\section{Hole 543A}

Nannofossils recovered from Hole 543A are poorly preserved, but are unusually common when found. Cores 1 through 6 and Core 8 are barren.

Core 7, Section 1 is barren, except for the occurrence of very rare Micula mura and Ceratolithoides kamptneri in very poorly preserved assemblages. If not reworked, this section is from the very top of the Maestrichtian.

Core 7, Section 3 and the lower part of Core 7, Section 2 all contain C. aculeus, Arkangelskiella, and large Prediscosphaera cretacea. The absence of Broinsonia par$c a$ in this interval suggests that it is not Campanian; it is most likely early Maestrichtian. Core 7, Section 4 is barren.

Sample 543A-9,CC and the bottom part of Section 543-9-1 are barren. Assemblages containing Quadrum nitidum, $Q$. geothicum, C. aculeus, and B. parca constricta are found near the top of Core 9, Section 1. This interval is assigned to the early late Campanian, based on the presence of the above species, but also on the absence of $Q$. trifidum.

Samples from Core 10, which include the contact with basement, are dated as early Campanian. This assignment is based on the co-occurrence of $B$. parca and Marthasterites furcatus.

\section{Radiolarians}

Radiolarians in varying abundances and states of preservation were recovered from both holes. The most significant recovery is a Cenozoic sequence ranging from lower Eocene to middle Miocene in the first hole.

\section{Hole 543}

A sparse Quaternary assemblage of radiolarians showing strong dissolution occurs in Section 543-1,CC. Cores 2 through 16 are barren. Radiolarians occur again in Section 543-17-1 and continue through the last core $(34, \mathrm{CC})$.

At the beginning of this long sequence (Sample 543$17-1,10-12 \mathrm{~cm})$ a few fragments are seen. One of these is identified as Calocycletta costata, dating the sample as no younger than the Dorcadospyris alata Zone (Riedel and Sanfilippo, 1978) of the middle Miocene. Sample $543-17-2,10-12 \mathrm{~cm}$ through $543-18-1,30-32 \mathrm{~cm}$ show increasing abundances and better states of preservation. They are placed in the Dorcadospyris alata Zone. The following species are present: $C$. costata, Cyrtocapsella cornuta, D. alata, Stichocorys delmontensis, and S. wolffii.

In Samples 543-18-2, 31-33 cm through 543-20-1, 70$72 \mathrm{~cm}, D$. dentata is consistently more abundant than its descendent, $D$. alata. This fact, along with the continuing occurrence of Calocycletta costata as well as C. virginis, Phormostichoartus corona, and Cannartus violina, places these samples in the Calocycletta costata Zone of the early Miocene. This correlates well with the beginning radiolarian sequence found at Site 541 (Core 48, Section 5).

Samples 543-20-2, 70-72 cm through 543-20,CC are assigned to the Stichocorys wolffii Zone because of the presence of $S$. wolffii, C. virginis, Carpocanopsis bramlettei, and Cyrtocapsella cornuta, and the absence of Calocycletta costata. Specimens are very abundant, occurring in highly diverse assemblages of moderate to good preservation.

There was no recovery from Core 21 . What little was recovered from Core 22 (Section 543-22-1, top-approximately $25 \mathrm{~cm}^{3}$ ) is assigned to the Stichocorys delmontensis Zone. S. delmontensis, C. virginis, Carpocanopsis bramlettei, Calocycletta serrata, Cyrtocapsella cornuta, C. tetrapera, D. ateuchus, and Eucyrtidium diaphanes are present. S. wolffii and Theocyrtis annosa are notably absent. Specimens are abundant and well preserved.

Samples 543-23-1, 145-147 cm through 543-24-1, 2-4 $\mathrm{cm}$ have common to abundant radiolarians, and the quality of preservation remains moderately good. This sequence is placed in the Lychnocanoma elongata Zone (straddling the Oligocene/Miocene boundary) because of the presence of $L$. elongata, Calocycletta virginis, $D$. ateuchus, and T. annosa and the absence of C. serrata, Cyrtocapsella cornuta, and $C$. tetrapera. This assignment indicates that the Cyrtocapsella tetrapera Zone may have occurred in the sediment lost in Core 22.

Samples 543-24-2, 40-42 cm through 543-26-1, 64-66 $\mathrm{cm}$ show a rapid decrease in the quality of preservation and great variability in abundance. The assemblage has a very low diversity that is dominated by $D$. ateuchus, $L$. elongata and T. annosa are absent. This places the samples in the Dorcadospyris ateuchus Zone.

The Theocyrtis tuberosa Zone occurs in Sample 543$26-2,43-45 \mathrm{~cm}$ through $543-27-2,126-128 \mathrm{~cm}$. The following species are noted: $D$. ateuchus, Lithocyclia angusta (C), L. aristotelis (R), T. tuberosa, and Tristylospyris triceros. Abundance and quality of preservation are increasing.

The Eocene/Oligocene boundary occurs between Sample 543-27-2, 126-128 cm and 543-27-3, 53-55 cm. Samples $543-27-3,53-55 \mathrm{~cm}$ through $543-28-3,73-75 \mathrm{~cm}$ are assigned to the Thyrsocyrtis bromia Zone. L. angusta drops out above the sequence, whereas $L$. aristotelis oc- 
curs with greater frequency. Lophocyrtis jacchia and Lychnocanoma amphitrite appear consistently and increase in abundance. Calocyclas turris and Thyrsocyrtis bromia occur in Sample 543-27-5, 104-106 cm through the end of the sequence. Both species are dominant members of the assemblage. Radiolarians are common to abundant and moderately well preserved.

No assemblage is assigned to the Podocyrtis goetheana Zone, although specimens of $P$. goetheana are frequently found in Sample 543-28-2, 40-42 cm.

Samples 543-28-4, 110-112 cm through 543-29-2, $72-$ $74 \mathrm{~cm}$ are assigned to the Podocyrtis chalara Zone. $P$. chalara appears consistently with common or greater abundance. Rhandolithus pipa occurs rarely. $P$. goetheana is absent. Specimens are common to abundant and moderately well preserved.

Sample 543-28,CC contains displaced material from the Thyrsocyrtis bromia zone.

Samples 543-29-3, 6-8 cm through 543-30-1, 10-12 $\mathrm{cm}$ are assigned to the Podocyrtis mitra Zone. P. chalara continuously decreases in abundance until it disappears in the middle of the sequence, whereas $P$. mitra is ever present with a fluctuating abundance. $P$. sinuosa is absent until the very end of the sequence. Specimens range from common to abundant and are moderately well preserved.

Samples 543-30-1, 38-40 cm through 543-30-3, 7-9 $\mathrm{cm}$ are assigned to the Podocyrtis ampla Zone. P. sinuosa is consistently more abundant than $P$. mitra, which disappears in the middle of the sequence. $P$. ampla is present throughout; $P$. phyxis is absent. Radiolarians are abundant to common and moderately well preserved.

Samples 543-30-3, 132-134 cm through 543-30-5, 129$131 \mathrm{~cm}$ are assigned to the Thyrsocyrtis triacantha Zone. $P$. phyxis and Eusyringium Fistuligerum are absent, whereas Theocotyle venezuelensis appears with increasing abundance. Radiolarians are common and moderately well preserved.

Sample 543-30-6, 60-62 cm through Section 543-31,CC are assigned to the Theocampe mongolfieri Zone due to the common presence of $T$. mongolfieri and to the absence of $E$. lagena. Specimens are abundant and moderately well preserved.

Samples 543-32-1, 37-39 cm through 543-32-5, 68-70 $\mathrm{cm}$ have abundant, very well preserved assemblages (for the most part). Specimens superficially similar to T. mongolfieri are common, but they lack strict longitudinal pore alignment and ribs. Calocycloma castum appears with increasing abundance. According to the zonal definition, these facts place the samples in the Theocotyle cryptocephala Zone (Riedel and Sanfilippo, 1978, amend.; Sanfilippo and Riedel, 1982).

Sections 543-32, CC through 543-34,CC show assemblages with decreasing abundances and all in very poor states of preservation. Specimens of C. castum, Calocyclas hispida, Lithochytris vespertilio, Phormocyrtis striata striata, and $T$. cryptocephala are seen rarely and cannot be used with confidence for zonation. Species of the genera Amphicraspedum and Spongodiscus dominate the assemblages.

\section{Hole 543A}

Offset drilling recovered one core from the surface, washed down to $332 \mathrm{~m}$ and continuously cored to $411 \mathrm{~m}$ at basement and $44 \mathrm{~m}$ into basalt.

Sections 543A-1-3 and 543A-1,CC contain a Quaternary radiolarian assemblage of low to moderate diversity, showing breakage and signs of dissolution.

Section 543A-H1-1 is barren of radiolarians.

After voids in the recovery, Samples 543A-H1-4, 95$97 \mathrm{~cm}$ through 543A-2-1, 95-97 cm contain common to few radiolarians in moderate to poor states of preservation. Sample 543A-H1-4, 95-97 cm contains specimens of Podocyrtis mitra (C), P. trachodes (R), and Sethochytris triconiscus, which bracket the sample, placing it in the upper half of the Podocyrtis mitra Zone. This correlates best with samples from Section 543-29-7.

The presence of rare specimens of Eusyringium fistuligerum and $P$. dorus and the common occurrence of $P$. sinuosa place Sample 543A-H1-5, 85-87 cm at the boundary of the Podocyrtis ampla/Thyrsocyrtis triacantha Zones. This correlates closest with Section 543-30-3. Radiolarians are abundant and moderately well preserved.

Sample 543A-H1-6, 64-66 cm contains no diagnostic species to indicate its zone. Specimens are few and very poorly preserved. Lithochytris vespertilio, $P$. sinuosa, and Rhandolithus pipa are dominant.

Section 543A-H1,CC contains both specimens of Theocorys anaclasta and Theocampe mongolfieri, which bracket it in the Theocampe mongolfieri Zone. Specimens of Thyrsocyrtis triacantha are rare with respect to those of $T$. tensa. Periphaena delta is absent. This places the sample near the middle of the zone, which correlates best with Section 543-31-1.

These correlations for Core $\mathrm{H} 1$ illustrate the characteristic of a washed core to collect samples from different intervals in the sediment column.

Sample 543A-2-1, 95-97 cm contains an assemblage of high diversity, common abundance, and poor preservation. T. mongolfieri is absent, and Calocycloma castum and Theocotyle cryptocephala are present. This sample is assigned to the Theocotyle cryptocephala Zone and correlates best with Section 543-32-4.

Section 543A-2-2 and 543A-2,CC contain radiolarians in common abundance but very poorly preserved. Several specimens of Calocycloma castum and Buryella clinata are seen throughout.

Cores 3,4 , and 5 contain radiolarians in varying abundances $(\mathrm{C}-\mathrm{R})$ but so poorly preserved that specimens are unrecognizable. Fragments of three specimens in Section $543 \mathrm{~A}-5, \mathrm{CC}$ are probably contaminants. Cores 6 through basement are barren. Rare fragments found at the contact are again thought to be contaminants.

\section{Foraminifers}

\section{Hole 543}

Hole 543 was drilled to $324 \mathrm{~m}$ sub-bottom. The upper 10 cores (approximately $96 \mathrm{~m}$ of section) contain foraminifers varying from sparse to abundant. 
Cores 1 through 3 are assigned to the lower Pleistocene Zone N22 of Blow. Specimens of Globorotalia (G.) truncatulinoides, G. (T.) tosaensis, and Globigerinoides obliquus obliquus are present throughout. Sample 543$3-4,30-32$ cm contains $G$. obliquus extremus and is assignable to Berggren's Zone PL6. As seen at Site 541, the top of Zone PL6 appears to occur in the lower Pleistocene.

The interval from Sample 543-3-4, 30-32 cm to Sample 543-4-6, 147-149 $\mathrm{cm}$ is assigned to Zone PL6. The Pliocene/Pleistocene boundary is placed below Section 543-3,CC on the basis of the nannofossil data.

Globorotalia (G.) miocenica occurs in Section 543$4, \mathrm{CC}$. This section is assigned to the upper Pliocene Zone PL5 (i.e., Zone N21 of Blow). Cores 4 and 5 are assigned to Zone PL5.

Core 6 is assigned to the upper Pliocene Zone PL4 (i.e., Zone N21 of Blow) on the basis of the presence of Globorotalia (G.) multicamerata.

Core 7 is assigned to that part of Zone N19 to N20 (i.e., PL3) below the extinction datum of Sphaeroidinellopsis subdehiscens paenedehiscens. The foraminifers in Core 7 are sparse. The lower/upper Pliocene boundary is placed above Sample 543-7-3, 55-56 cm, on the basis of the nannofossil data (Bergen, this volume).

Cores 8 to 10 contain only sparse foraminifers; most of which are broken. Thus no zonal assignments are attempted.

Cores 11 through 34 are barren of foraminifers.

\section{Hole 543A}

In Hole 543A, the first $10 \mathrm{~m}$ below the seafloor are cored. The hole was then washed to $332 \mathrm{~m}$ and continuously cored to $455 \mathrm{~m}$.

No diagnostic planktonic foraminifers were observed throughout the cored interval. Some benthic foraminifers assignable to the Upper Cretaceous, Campanian to Maestrichtian (Hemleben and Troester, this volume), are found from Cores 6 to 10 .

\section{PALEOENVIRONMENT}

Recent seafloor sediments of Site 543 were deposited about $450 \mathrm{~m}$ below the local calcite compensation depth (CCD). As a consequence, the top of Core 1 of Hole 543 is barren of calcareous fossils and Cores 1 through 8 , Section 1 contain mostly moderate to poorly preserved assemblages of planktonic foraminifers. In general the sedimentation rate of Site 543 is considerably lower compared with Site 541. Thus it is not possible to obtain the same resolution of events such as climatic changes. However, changes in preservation of calcareous fossils in Cores 1 through 3 may reflect the glacial and interglacial phases during the Quaternary. Core 3 seems to represent mostly the Nebraskan (Berger, 1977) interval. A comparison of the Nebraskan preservational peaks at Sites 541 and 543 demonstrates a slight shift (Site 541) toward the Pliocene; however, this shift may be influenced more by gravity flow deposits than by climatic changes. Samples of glacial intervals (e.g., Nebraskan) contain cold-water species (e.g., G. truncatulinoides, $G$. inflata, and Neogloboquadrina cf. pachyder- $m a$ ) along with the normal tropical assemblage. The cooling of the water mass is less rapid at the Pliocene/ Pleistocene boundary in low latitudes than in high latitudes. The first appearance of the subtropical species $G$. truncatulinoides coincides with the Nebraskan glacial interval and not necessarily with the Pliocene/Pleistocene boundary.

Compared with Site 541, the preservation is less, indicating earlier deposition closer to the CCD during the late Pliocene. Sediments of Sections 543-7,CC through 543-10,CC were deposited close to or below the CCD. Siliceous microfossils first appear in Core 17, Section 1, indicating a depositional environment definitely below the CCD.

Sediments of Hole 543A (Cores 1 through 6) contain no calcareous microfossil assemblages and thus are deposited below the CCD. In these cores little or no bioturbation can be seen. The occurrence of numerous arenaceous and calcareous benthic foraminifers together with increasing bioturbation in Cores 6 to 10, Section 1 indicates better bottom conditions than seen in Cores 4 to 5 . The first occurrence of calcareous benthic foraminifers in Core 7, Section 2 may indicate a depositional environment above the CCD. However, the abundance of benthic foraminifers or the ratio of arenaceous-calcareous foraminifers changes rather drastically in each core (Cores 7 through 10) and may reflect the relative movement of the CCD. In addition, the total lack of planktonic foraminifers (tests or even fragments) points toward a relict fauna of abyssal, benthic species. Thus the depositional environment can be placed close to the CCD. In comparing Holes 541, 542, and 543A with the Barbados outcrops in respect to the foraminiferal abundance, it is obvious that the depositional environment of Barbados, especially the Oceanic Formation, must be placed several thousand meters higher up the slope than the sites of Leg 78A.

\section{BASALTS}

\section{Lithology}

Altogether, $35.9 \mathrm{~m}$ of basalt were recovered in Hole $543 \mathrm{~A}$, out of $44 \mathrm{~m}$ cored, for a recovery rate of $81 \%$. This is one of the highest rates of recovery for a singlebit hole into basement ever obtained by DSDP, and remarkably, was even higher than the rate of recovery in the sediments. The recovery was so exceptional that it was possible to log each pillow recovered on the igneous rock description forms, and determine that a total of 59 separate cooling units had been cored. Coring in basaltic basement began $3 \mathrm{~m}$ into the interval encompassed by Core 10 of Hole 543A, and proceeded through Core 16. It was terminated in order to leave sufficient time for logging and downhole experiments.

The reasons for the exceptional basalt recovery were (1) alteration was sufficient to have "healed" the abundant fractures typical of pillowed basalts, and (2) interpillow voids were largely filled, or at least lined, with spectacular, virtually geoidal calcite, which preserved entire glass selvages on many pillows. The pillows themselves are fairly small, rarely more than $1 \mathrm{~m}$ thick, and usu- 
ally only a few tens of centimeters thick. Glass selvages were commonly curved, and were recovered on both the top and bottom, as well as the sides, of pillows. Some pillows were cored precisely on their edges, resulting in strikingly curved marginal glass zones that extend for several tens of centimeters through several pieces of rock. There were also three glass rinds that changed trend abruptly, curving sharply back upon themselves, representing places where the pillows formed "buds" one from another, during eruption.

The basalts vary from sparsely to strongly phyric, with plagioclase phenocrysts being most abundant and clinopyroxene and olivine phenocrysts occurring in some samples. The distribution of these phenocrysts varies mainly on a sample to sample basis, making it difficult to define distinctive petrographic units. However, phenocrysts are most abundant in Core 10 , and again in Cores 14 to 16 .

The most important downhole lithologic variations concern alteration and the distribution of interpillow sediments. Alteration is quite extensive in Cores 10 through 12. The rocks are pervasively altered to a dark grayish brown color, and some, mainly at pillow margins, are an almost brick-colored orange brown, highlighting the pale gray plagioclase phenocrysts. Through Core 13, calcite is the major mineral lining fractures, which, even in pillow interiors, can be 1 to $2 \mathrm{~cm}$ wide. Below this core, fractures are narrower-never more than $0.5 \mathrm{~cm}$ wide-and are lined either with calcite or green clays. Below Core 12, Section 4, the extent of the grayish brown zones of oxidative alteration diminishes, and most of the basalts are gray and dark gray in color. Clays identified by X-ray diffraction in these cores are primarily celadonite, mixed-layer clays, and dioctahedral smectite, all of which occur in the same samples, suggesting predominantly oxidative conditions of alteration. Trioctahedral smectite was found in only one sample. The celadonite-mixed-layer clay association forms distinctive dark bluish green encrustations on fracture surfaces, and is especially prevalent in Cores 14 and 15 , with an additional occurrence in Core 16, Section 5 . Primarily, there are only very narrow veins of calcite in the latter core.

Inter- and intrapillow sediments occur only in Cores 10 to 13 . They include one sample with brown claystone between two pieces of glass, calcite-cemented basaltic sands, and one example of a wide fracture partially filled with brown claystone, then completely filled with calcite above the claystone. The claystone/calcite contact is horizontal, implying that clays partly filled the fracture well after it had formed in the solidified rock. The sediments in the basalts therefore probably only filled in void spaces as they were deposited. The pillows did not "intrude" soft sediments.

\section{Petrography}

Seventeen thin sections reveal the Hole 543A basalts to be petrographically typical of many previously described basalts from the Mid-Atlantic Ridge. They have the textures and crystal morphologies typical of pillows, namely zones of spherulites adjacent to glassy rinds be- coming coarser grained and more microlitic toward pillow interiors. The principal variations occur in the abundances and, to some extent, the varieties of phenocrysts, and in the types of alteration. Plagioclase phenocrysts occur in all thin sections, and are as abundant as $15 \%$ in some of the sections from Cores 14 to 16 . There are two types: large plagioclase megacrysts, often having inclusions of spherulitic devitrified glass and sharp exterior normal zones, and euhedral or tabular smaller phenocrysts, which are more numerous. Both types can occur as glomerocrysts, although the larger megacrysts form rather massive glomerocrysts and the smaller type frequently is only loosely clumped. Rare altered olivine is associated with the megacrysts, and clinopyroxene occurs with the smaller euhedral plagioclase phenocrysts. Single spinel crystals occur in three samples. The abundance of clinopyroxene phenocrysts, the rarity of olivine, and the rarity of chrome spinel, imply that the basalts are fairly extensively fractionated. The groundmass consists of plagioclase microlites or spherulites, spherulitic to dendritic clinopyroxene, and titanomagnetite, almost invariably altered to reddish iron hydroxides.

The phenocryst distribution in the cores can be summarized as follows: (1) Cores 10 to 11, Section 1: moderately plagioclase-olivine phyric basalt; (2) Core 11, Section 1 to Core 12 , Section 2 : sparsely to moderately plagioclase phyric basalt with rare augite phenocrysts and no calcic plagioclase megacrysts or glomerocrysts; (3) Core 12, Section 2 to Core 14: sparsely to moderately plagioclase-olivine phyric basalts; and (4) Cores 15 and 16: moderately to strongly plagioclase-clinopyroxeneolivine phyric basalt.

The other striking petrographic feature of these basalts is the distribution and type of secondary minerals. In Cores 10 and 11 , there has been significant replacement of plagioclase by K-feldspar and calcite, with associated almost complete oxidation of groundmass titanomagnetite. The K-feldspar and calcite replacements are intimately associated texturally, and there is strong crystallographic control in the plagioclases on the occurrence of these secondary minerals.

Below Core 12, alteration is confined to partial replacement of the groundmass and olivines by green or blue green clays and iron hydroxides, filling in of vesicles by clays, iron hydroxides, and pyrite, ofttimes strikingly zoned, and veining by calcite with or without clays. Formation of iron hydroxides in the groundmass or in vesicles is more extensive near cracks. This phenomenon can even be seen macroscopically by tracing narrow calcite veinlets into pillow interiors. No matter how narrow these veinlets are, they are usually accompanied by narrow parallel zones 1 to $2 \mathrm{~mm}$ wide of oxidative alteration and iron hydroxide coloration. In some cases, particularly deeper in the cored basement, the calcite veins themselves either line or are lined with reddish iron hydroxide fillings. Overall, the alteration in Hole $543 \mathrm{~A}$ basalts is very similar to that of basalts from Hole 417A, drilled during Leg 51, particularly in regard to the formation of K-feldspar near the top of basement, and the generally oxidative character of alteration elsewhere. The primary petrology and a summary of the 
features of alteration are presented in more detail in chapters by Natland et al. (this volume) and Bougault et al. (this volume).

\section{PHYSICAL PROPERTIES}

The physical properties of cores recovered from Site 543 are similar to the properties measured in cores from Sites 541 and 542.

\section{Sonic Velocity}

An average of two ultrasonic velocity measurements were made on samples from each core from Site 543 (Table 3). The variation in compressional velocity throughout the entire site, excluding the basaltic basement rocks at the bottom of the hole, is uniform and generally small. As can be seen in Figure 7, the increase in velocity down to basement in the hole is very slight, very gradual, and linear (except for a few scattered points).

We converted the vertical components of sonic velocities to acoustic impedance, defined as

$$
z=\rho \cdot V_{\mathrm{p}}
$$

where $\rho=$ density and $V_{\mathrm{p}}=$ vertical velocity. As can be seen in Figure 7, the acoustic impedance at Site 543 increases uniformly down the hole, starting at about $2.0 \times 10^{5} \mathrm{~g} / \mathrm{cm}^{2} \mathrm{~s}$ near the seafloor and increasing to about $3.0 \times 10^{5} \mathrm{~g} / \mathrm{cm}^{2} \mathrm{~s}$ near the bottom of the hole.

In order to describe the variations in velocity with depth, we calculated mean velocities for given depth measurements as well as for the entire site above basaltic basement (Table 4). The average velocities parallel and perpendicular to the cores (exclusive of basalt basement samples) are virtually indistinguishable for the entire site. This relationship suggests that sedimentary material from the site is acoustically isotropic.

In order to test whether sedimentary samples from Site 543 are indeed acoustically isotropic, we computed relative anisotropy for each core sample from the relationship:

$$
\text { Anisotropy } A_{\mathrm{n}}(\%)=100 \times\left(V_{\|}-V_{\perp} / V_{\|}+V_{\perp}\right)
$$

where $V_{\|}$and $V_{\perp}$ are the velocity values parallel and perpendicular to bedding, respectively. The results of these calculations are shown in Table 5. For all 61 computations, the average anisotropy, $\bar{A}_{\mathrm{n}}$, is $0.395 \%$ with a standard deviation of $1.103 \%$. The average anisotropy is slightly positive albeit very small. A cursory examination of Table 5 suggests that the slightly positive anisotropic effect discovered at Site 543 is confined to the sedimentary section below $300 \mathrm{~m}$. Above $300 \mathrm{~m}$, the drilled section at Site 543 is isotropic, as are the drilled sections at adjacent Sites 541 and 542 .

\section{Porosity, Density, and Water Content}

Plots of water content, porosity, and density are shown in Figure 8. Porosity is also plotted versus depth in Figure 4. The density averages about $1.50 \mathrm{~g} / \mathrm{cm}^{3}$ from the seafloor to a sub-bottom depth of about $190 \mathrm{~m}$. We have no sample data between about 190 and $210 \mathrm{~m}$ at

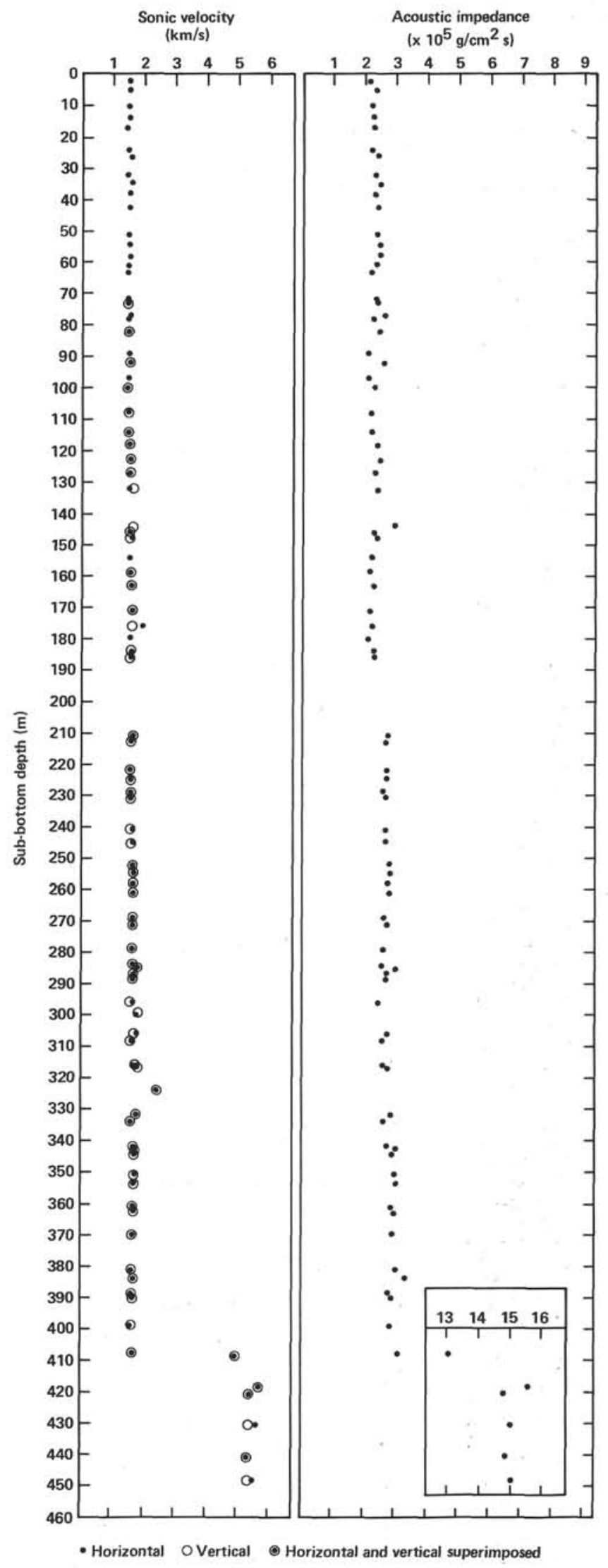

Figure 7. Plot of acoustic impedance and sonic velocity versus subbottom depth at Site 543. (Sonic velocities are calculated from recovered core samples and are not corrected to in situ values. Acoustic impedance values also are not corrected to in situ values.) 
Table 3. Summary of physical properties for Site 543 .

\begin{tabular}{|c|c|c|c|c|c|c|c|c|c|c|c|c|c|}
\hline \multirow{4}{*}{$\begin{array}{c}\text { Sample } \\
\text { (core-section, } \\
\text { interval in cm) }\end{array}$} & \multirow{4}{*}{$\begin{array}{l}\text { Sub-bottom } \\
\text { depth } \\
\text { (m) }\end{array}$} & \multirow{3}{*}{\multicolumn{2}{|c|}{$\begin{array}{l}\text { Sonic } \\
\text { velocity } \\
(\mathrm{km} / \mathrm{s})\end{array}$}} & \multicolumn{4}{|c|}{ 2-min. GRAPE } & & & & & & \\
\hline & & & & \multirow{2}{*}{\multicolumn{2}{|c|}{$\begin{array}{l}\text { Wet-bulk } \\
\text { density } \\
\left(\mathrm{g} / \mathrm{cm}^{3}\right)\end{array}$}} & & & & avimetrics & & & & \\
\hline & & & & & & $\begin{array}{r}\text { Poro } \\
(\%)\end{array}$ & & $\begin{array}{l}\text { Wet-bulk } \\
\text { density }\end{array}$ & Porosity & $\begin{array}{l}\text { Water } \\
\text { content }\end{array}$ & $\begin{array}{c}\text { impedance } \\
\left(\times 10^{5} \mathrm{~g} / \mathrm{cm}^{2} \mathrm{~s}\right)\end{array}$ & $\begin{array}{l}\text { Shear } \\
\text { strength }\end{array}$ & $\begin{array}{c}\text { conductivity } \\
{\left[\times 10^{-3} \text { (cal/ }\right.}\end{array}$ \\
\hline & & $\mathbf{H}^{\mathrm{a}}$ & $v^{a}$ & $\mathrm{H}^{\mathrm{a}}$ & $v^{a}$ & $\mathrm{H}^{\mathrm{a}}$ & $v^{a}$ & $\left(\mathrm{~g} / \mathrm{cm}^{3}\right)$ & $(\%)$ & $(\%)$ & & $(\mathrm{kPa})$ & $\mathrm{cm} \cdot \mathrm{s} \cdot \mathrm{deg}) \mathrm{l}$ \\
\hline Hole 543 & & & & & & & & & & & & & \\
\hline $1-2,56-59$ & 2 & 1.490 & & 1.35 & & 80.6 & & 1.41 & 76.2 & 55.6 & 2.10 & & \\
\hline $1-2,105-108$ & 3 & & & & & & & & & & & 18.1 & \\
\hline $1-4,116-118$ & 5 & 1.499 & & 1.50 & & 71.6 & & 1.54 & 65.3 & 43.4 & 2.31 & & \\
\hline $1-4,105-108$ & 6 & & & & & & & & & & & 17.3 & \\
\hline $1-7,90-93$ & 10 & 1.493 & & 1.49 & & 72.2 & & 1.50 & 70.8 & 48.3 & 2.24 & & \\
\hline $1-7,103-106$ & 10 & & & & & & & & & & & 13.2 & \\
\hline $2-2,17-20$ & 12 & & & & & & & & & & & 9.1 & \\
\hline $2-3,44-47$ & 14 & 1.490 & & 1.49 & & 72.2 & & 1.52 & 64.6 & 43.6 & 2.26 & & \\
\hline $2-5,29-32$ & 17 & & & & & & & & & & & 9.1 & \\
\hline $2-5,44-47$ & 17 & 1.545 & & 1.49 & & 72.2 & & 1.57 & 64.7 & 42.2 & 2.28 & & \\
\hline $3-3,120-123$ & 24 & 1.480 & & 1.49 & & 72.2 & & 1.48 & 71.1 & 49.2 & 2.19 & & \\
\hline $3-4,13-16$ & 25 & & & & & & & & & & & 18.5 & \\
\hline $3-5,40-43$ & 26 & 1.545 & & 1.52 & & 70.5 & & 1.55 & 67.9 & 44.9 & 2.39 & & \\
\hline $3-7,19-22$ & 29 & & & & & & & & & & & 6.6 & \\
\hline $4-2,60-63$ & 32 & 1.492 & & 1.56 & & 71.6 & & 1.54 & 66.7 & 44.3 & 2.30 & & \\
\hline $4-3,100-103$ & 34 & & & & & & & & & & & 27.2 & \\
\hline $4-4,60-63$ & 35 & 1.519 & & 1.57 & & 67.5 & & 1.60 & 61.9 & 39.6 & 2.43 & & \\
\hline $4-6,97-100$ & 38 & & & & & & & & & & & 35.0 & \\
\hline $4-6,130-133$ & 38 & 1.504 & & 1.49 & & 72.2 & & 1.53 & 65.6 & 44.0 & 2.30 & & \\
\hline $5-3,13-16$ & 42 & 1.500 & & 1.50 & & 71.0 & & 1.56 & 63.3 & 41.7 & 2.34 & & \\
\hline $5-3,21-25$ & 42 & & & & & & & & & & & 18.1 & \\
\hline $5-3,40$ & 42 & & & & & & & & & & & & 2.533 \\
\hline $6-2,135-137$ & 51 & 1.496 & & 1.43 & & 75.8 & & 1.56 & 61.4 & 40.4 & 2.33 & & \\
\hline $6-4,70-72$ & 54 & 1.506 & & 1.58 & & 66.9 & & 1.61 & 63.8 & 40.6 & 2.42 & & \\
\hline $6-4,82-86$ & 54 & & & & & & & & & & & 17.3 & \\
\hline $6-6,97-100$ & 57 & & & & & & & & & & & 32.5 & \\
\hline $6-7,13-16$ & 58 & & & & & & & & & & & 63.0 & \\
\hline $6-7,21-23$ & 58 & 1.519 & & 1.58 & & 66.9 & & 1.60 & 63.2 & 40.5 & 2.43 & & \\
\hline $7-2,86-89$ & 60 & & & & & & & & & & & 21.4 & \\
\hline $7-2,94-97$ & 61 & 1.482 & & 1.55 & & 68.7 & & 1.58 & 63.8 & 41.4 & 2.34 & & \\
\hline $7-3,138-141$ & 62 & & & & & & & & & & & 77.8 & \\
\hline $7-4,41-44$ & 63 & 1.471 & & 1.56 & & 68.1 & & 1.55 & 67.3 & 44.4 & 2.28 & & \\
\hline $7-4,47-50$ & 63 & & & & & & & & & & & 26.4 & \\
\hline $8-3,104-107$ & 72 & & & & & & & & & & & 44.9 & \\
\hline $8-3,124-128$ & 72 & 1.485 & & 1.55 & & 68.7 & & 1.60 & 62.2 & 39.9 & 2.38 & & \\
\hline $8-4,50-54$ & 73 & 1.488 & 1.493 & 1.57 & & 67.5 & & 1.61 & 62.4 & 39.6 & 2.40 & & \\
\hline $8-4,69-72$ & 73 & & & & & & & & & & & 72.1 & \\
\hline $8, C C(5-8)$ & 77 & & & & & & & & & & & 37.1 & \\
\hline $8, C C(10-13)$ & 77 & 1.523 & & 1.63 & & 63.9 & & 1.71 & 55.8 & 33.3 & 2.60 & & \\
\hline $9-1,92-95$ & 78 & & & & & & & & & & & 12.4 & \\
\hline $9-1,104-107$ & 78 & 1.482 & & 1.47 & & 72.2 & & 1.53 & 65.8 & 44.1 & 2.27 & & \\
\hline $9-4,65-68$ & 82 & 1.493 & 1.502 & 1.50 & 1.56 & 71.6 & 68.1 & 1.65 & 59.0 & 36.6 & 2.48 & & \\
\hline $9-4,73-76$ & 82 & & & & & & & & & & & 45.3 & \\
\hline $9-6,82-85$ & 85 & & & & & & & & & & & 39.5 & \\
\hline $9-6,120$ & 86 & & & & & & & & & & & & 2.644 \\
\hline $10-2,82-86$ & 89 & 1.480 & & 1.37 & & 79.4 & & 1.41 & 71.2 & 51.8 & 2.09 & & \\
\hline $10-2,92-95$ & 89 & & & & & & & & & & & 11.8 & \\
\hline $10-4,81-84$ & 92 & 1.529 & 1.529 & 1.66 & 1.65 & 62.1 & 62.7 & 1.68 & 59.1 & 36.1 & 2.57 & & \\
\hline $10-4,98-101$ & 92 & & & & & & & & & & & 82.4 & \\
\hline $10-5,6-9$ & 93 & & & & & & & & & & & 59.3 & \\
\hline $11-1,101-103$ & 97 & & & & & & & & & & & 19.8 & \\
\hline $11-1,119-123$ & 97 & 1.470 & & 1.43 & & 75.8 & & 1.40 & 74.9 & 54.8 & 2.06 & & \\
\hline $11-3,49-52$ & 100 & & & & & & & & & & & 48.0 & \\
\hline $11-3,59-63$ & 100 & 1.463 & 1.489 & 1.51 & 1.52 & 71.0 & 70.4 & 1.51 & 69.3 & 46.9 & 2.25 & & \\
\hline $12-2,110-113$ & 108 & & & & & & & & & & & 31.3 & \\
\hline $12-2,117-121$ & 108 & 1.485 & 1.477 & 1.41 & 1.44 & 77.0 & 75.2 & 1.46 & 72.3 & 50.6 & 2.16 & & \\
\hline $12-4,82-85$ & 111 & & & & & & & & & & & 96.4 & \\
\hline $12-6,100$ & 114 & & & & & & & & & & & & 2.644 \\
\hline $12-6,117-120$ & 114 & & & & & & & & & & & 41.2 & \\
\hline $12-6,125-129$ & 114 & 1.487 & 1.497 & 1.44 & 1.44 & 75.2 & & 1.49 & 71.1 & 48.9 & 2.23 & & \\
\hline $13-2,104-107$ & 118 & & & & & & & & & & & 53.5 & \\
\hline $13-2,116-120$ & 118 & 1.499 & 1.505 & 1.52 & 1.56 & 71.0 & 68.1 & 1.54 & 67.8 & 45.0 & 2.32 & & \\
\hline $13-3,144-147$ & 119 & & & & & & & & & & & 73.3 & \\
\hline $13-6,63-66$ & 123 & & & & & & & & & & & 76.6 & \\
\hline $13-6,70-74$ & 123 & 1.520 & 1.511 & 1.69 & 1.60 & 60.3 & 65.7 & 1.63 & 65.4 & 41.1 & 2.46 & & \\
\hline $14-1,83-86$ & 125 & & & & & & & & & & & 32.9 & \\
\hline $14-2,80-83$ & 127 & 1.520 & 1.512 & 1.49 & 1.50 & 72.2 & 71.6 & 1.52 & 71.7 & 48.4 & 2.30 & & \\
\hline $14-3,103-106$ & 129 & & & & & & & & & & & 24.7 & \\
\hline $14-5,97-100$ & 132 & & & & & & & & & & & 13.2 & \\
\hline $14-5,110-113$ & 132 & 1.500 & 1.662 & 1.39 & & 78.2 & & 1.43 & 70.9 & 50.6 & 2.38 & & \\
\hline
\end{tabular}


Table 3. (Continued).

\begin{tabular}{|c|c|c|c|c|c|c|c|c|c|c|c|c|c|}
\hline \multirow{4}{*}{$\begin{array}{c}\text { Sample } \\
\text { (core-section, } \\
\text { interval in cm) }\end{array}$} & \multirow{4}{*}{$\begin{array}{l}\text { Sub-bottom } \\
\text { depth } \\
\text { (m) }\end{array}$} & \multicolumn{6}{|c|}{ 2-min. GRAPE } & \multirow{2}{*}{\multicolumn{3}{|c|}{ Gravimetrics }} & \multirow{4}{*}{$\begin{array}{c}\text { Acoustic } \\
\text { impedance } \\
\left(\times 10^{5} \mathrm{~g} / \mathrm{cm}^{2} \mathrm{~s}\right) \\
\mathrm{V}^{\mathrm{a}}\end{array}$} & \multirow{4}{*}{$\begin{array}{l}\text { Shear } \\
\text { strength } \\
(\mathrm{kPa})\end{array}$} & \\
\hline & & & & Wet- & & & & & & & & & Thermal \\
\hline & & $\begin{array}{l}\text { velo } \\
(\mathrm{km}\end{array}$ & & & & $\begin{array}{r}\text { Poros } \\
(\%)\end{array}$ & & $\begin{array}{l}\text { Wet-bulk } \\
\text { density }\end{array}$ & Porosity & $\begin{array}{l}\text { Water } \\
\text { content }\end{array}$ & & & $\begin{array}{l}\text { conductivity } \\
{\left[\times 10^{-3} \text { (cal) }\right.}\end{array}$ \\
\hline & & $\mathrm{H}^{\mathrm{a}}$ & $v^{a}$ & $\mathrm{H}^{\mathrm{a}}$ & $v^{a}$ & $\mathbf{H}^{\mathrm{a}}$ & $v^{a}$ & & $(\%)$ & & & & \\
\hline Hole 543 (Cont.) & & & & & & & & & & & & & \\
\hline $15-3,36-39$ & 137 & & & & & & & & & & & 39.5 & \\
\hline $15, \mathrm{CC}$ & 144 & & 1.643 & 1.77 & 1.80 & 55.5 & 53.7 & 1.77 & 58.5 & 33.9 & 2.91 & & \\
\hline $16-2,73-76$ & 146 & & & & & & & & & & & 28.8 & \\
\hline $16-2,92-95$ & 146 & 1.526 & 1.533 & 1.47 & 1.50 & 73.4 & 71.6 & 1.49 & 74.4 & 51.3 & 2.28 & & \\
\hline $16-4,24-27$ & 148 & 1.551 & 1.506 & 1.56 & 1.56 & 68.1 & & 1.54 & 71.0 & 47.3 & 2.32 & & \\
\hline $16-4,76-79$ & 149 & & & & & & & & & & & 43.2 & \\
\hline $17-1,70-73$ & 154 & 1.527 & & 1.49 & 1.49 & 72.2 & & 1.44 & 76.2 & 54.1 & 2.20 & & \\
\hline $17-1,77-80$ & 154 & & & & & & & & & & & 62.6 & \\
\hline $17-4,135-138$ & 159 & 1.518 & 1.505 & 1.34 & 1.35 & 81.2 & 80.6 & 1.41 & 76.5 & 55.7 & 2.12 & & \\
\hline $18-1,65-68$ & 163 & 1.581 & 1.565 & 1.40 & 1.46 & 77.6 & 74.0 & 1.46 & 74.9 & 52.6 & 2.28 & & \\
\hline $18-6,99-102$ & 171 & 1.604 & 1.598 & 1.40 & 1.34 & 74.0 & 81.7 & 1.40 & 76.2 & 55.8 & 2.24 & & \\
\hline $19-3,10-13$ & 175 & & & & & & & & & & & 32.9 & \\
\hline $19-3,93-97$ & 176 & 1.946 & 1.592 & 1.34 & 1.33 & 81.2 & 81.8 & 1.39 & 76.4 & 56.4 & 2.21 & & \\
\hline $19-3,80-84$ & 176 & 1.596 & 1.564 & 1.40 & 1.36 & 77.6 & 80.0 & 1.43 & 73.6 & 52.6 & 2.24 & & \\
\hline $19-5,8-11$ & 178 & & & & & & & & & & & 42.8 & \\
\hline $19-6,8-11$ & 180 & & & & & & & & & & & 19.8 & \\
\hline $19-6,13-16$ & 180 & 1.514 & & 1.41 & & 77.0 & & 1.39 & 76.5 & 56.2 & 2.10 & & \\
\hline $20-2,88-91$ & 184 & & & & & & & & & & & 105.4 & \\
\hline $20-2,98-101$ & 184 & 1.556 & 1.551 & 1.47 & 1.38 & 73.4 & 78.8 & 1.44 & 74.1 & 52.7 & 2.23 & & \\
\hline $20-3,88-92$ & 186 & 1.547 & 1.536 & 1.42 & 1.42 & 76.4 & & 1.49 & 71.5 & 49.2 & 2.29 & & \\
\hline $20-3,94-97$ & 186 & & & & & & & & & & & 90.6 & \\
\hline $20-4,85-88$ & 187 & & & & & & & & & & & $>118.6$ & \\
\hline $20-4,100$ & 187 & & & & & & & & & & & & 2.384 \\
\hline $23-1,128-131$ & 211 & & & & & & & & & & & 112.0 & \\
\hline $23-1,138-142$ & 211 & 1.619 & 1.580 & 1.66 & 1.74 & 62.1 & 57.3 & 1.70 & 58.9 & 35.5 & 2.69 & & \\
\hline $23-2,99-103$ & 213 & 1.578 & 1.579 & 1.64 & 1.59 & 63.3 & 66.3 & 1.68 & 61.9 & 37.9 & 2.65 & & \\
\hline $23-2,108-111$ & 213 & & & & & & & & & & & 112.0 & \\
\hline $24-2,95-97$ & 222 & & & & & & & & & & & 75.8 & \\
\hline $24-2,108-111$ & 222 & 1.563 & 1.560 & 1.66 & 1.70 & 62.1 & 58.9 & 1.68 & 62.1 & 37.9 & 2.62 & & \\
\hline $24-3,98-100$ & 224 & & & & & & & & & & & 118.6 & \\
\hline $24-4,103-106$ & 225 & 1.572 & 1.575 & 1.74 & 1.76 & 57.3 & 56.1 & 1.71 & 61.1 & 36.7 & 2.69 & & \\
\hline $24-4,108-110$ & 225 & & & & & & & & & & & 101.3 & \\
\hline $25-1,7-10$ & 229 & & & & & & & & & & & 54.4 & \\
\hline $25-1,11-15$ & 229 & 1.578 & 1.539 & 1.65 & 1.68 & 62.7 & 60.9 & 1.67 & 61.9 & 37.9 & 2.57 & & \\
\hline $25-2,55-59$ & 231 & 1.557 & 1.551 & 1.65 & 1.68 & 62.7 & 60.9 & 1.68 & 60.2 & 36.5 & 2.61 & & \\
\hline $25-2,65-68$ & 231 & & & & & & & & & & & 67.5 & \\
\hline $25-3,15-18$ & 232 & & & & & & & & & & & 66.7 & \\
\hline $26-2,54-57$ & 241 & 1.604 & 1.541 & 1.72 & 1.72 & 58.5 & & 1.71 & 59.3 & 35.5 & 2.64 & & \\
\hline $\begin{array}{l}26-2,102-105 \\
26-4,79-82\end{array}$ & $\begin{array}{l}241 \\
244\end{array}$ & & & & & & & & & & & 106.2 & \\
\hline $26-4,79-82$ & $\begin{array}{l}244 \\
245\end{array}$ & 1.620 & 1.570 & 1.63 & 1.63 & 61.9 & & 1.70 & 57.9 & 34.8 & 2.67 & 112.0 & \\
\hline $\begin{array}{l}26-5,55-58 \\
26-6,70-73\end{array}$ & $\begin{array}{l}245 \\
247\end{array}$ & & & & & & & & & & & 125.2 & \\
\hline $27-3,120-123$ & 252 & 1.625 & 1.610 & 1.68 & 1.63 & 60.9 & 61.9 & 1.70 & 59.2 & 35.8 & 2.74 & 120.2 & \\
\hline $27-5,27-30$ & 254 & & & & & & & & & & & 79.1 & \\
\hline $27-5,83-86$ & 255 & 1.613 & 1.612 & 1.67 & 1.61 & 61.5 & 65.1 & 1.70 & 58.1 & 35.1 & 2.74 & & \\
\hline $28-1,71-74$ & 258 & 1.629 & 1.622 & 1.54 & 1.61 & 69.3 & 65.1 & 1.66 & 59.2 & 36.5 & 2.69 & & \\
\hline $28-2,101-104$ & 260 & & & & & & & & & & & 102.1 & \\
\hline $28-3,59-62$ & 261 & 1.646 & 1.607 & 1.76 & 1.70 & 56.1 & 59.7 & 1.73 & 57.0 & 33.8 & 2.78 & & \\
\hline $28-4,97-100$ & 263 & & & & & & & & & & & 117.8 & \\
\hline $28-4,125$ & 263 & & & & & & & & & & & & 2.588 \\
\hline $29-2,56-60$ & 269 & 1.643 & 1.617 & 1.53 & 1.53 & 69.9 & & 1.61 & 59.3 & 37.6 & 2.60 & & \\
\hline $\begin{array}{l}29-2,65-68 \\
29-3,50-53\end{array}$ & $\begin{array}{l}269 \\
271\end{array}$ & & & & & & & & & & & $\begin{array}{l}121.9 \\
123.5\end{array}$ & \\
\hline $29-3,61-65$ & 271 & 1.623 & 1.610 & 1.56 & 1.55 & 68.1 & 68.7 & 1.66 & 58.5 & 36.1 & 2.67 & 123.5 & \\
\hline $29-6,72-75$ & 275 & & & & & & & & & & & $>115.3$ & \\
\hline $30-2,110-113$ & 279 & 1.603 & 1.618 & 1.55 & 1.50 & 68.7 & 71.6 & 1.61 & 59.6 & 38.0 & 2.60 & & \\
\hline $30-2,118-120$ & 279 & & & & & & & & & & & $>120.3$ & \\
\hline $30-4,38-41$ & 281 & & & & & & & & & & & 90.6 & \\
\hline $30-5,125-128$ & 284 & 1.634 & 1.641 & 1.48 & 1.47 & 72.8 & 73.4 & 1.58 & 52.7 & 34.3 & 2.59 & & \\
\hline $30-5,134-137$ & 284 & & & & & & & & & & & 102.1 & \\
\hline $30-6,82-88$ & 285 & 1.784 & 1.731 & 1.56 & 1.57 & 68.1 & 67.5 & 1.70 & 53.0 & 32.0 & 2.94 & & \\
\hline $31-1,45-48$ & 286 & & & & & & & & & & & 62.6 & \\
\hline $31-1,77-81$ & 287 & 1.631 & 1.634 & 1.53 & 1.54 & 69.4 & 69.3 & 1.63 & 58.3 & 36.6 & 2.66 & & \\
\hline $31-2,8-11$ & 288 & 1.604 & 1.630 & 1.46 & 1.51 & 74.0 & 71.0 & 1.62 & 58.7 & 37.1 & 2.64 & & \\
\hline $31-2,17-20$ & 288 & & & & & & & & & & & 59.3 & \\
\hline $32-1,50-53$ & 296 & & & & & & & & & & & 79.1 & \\
\hline $32-1,81-84$ & 296 & 1.614 & 1.548 & 1.46 & 1.41 & 74.0 & 77.0 & 1.55 & 63.6 & 42.1 & 2.40 & & \\
\hline $32-2,94-96$ & 298 & & & & & & & & & & & 74.9 & \\
\hline $32-3,85-87$ & 299 & & & & & & & & & & & 64.2 & \\
\hline $32-4,43-47$ & 300 & 1.755 & 1.824 & 1.47 & 1.54 & 73.4 & 69.3 & 1.62 & 58.3 & 36.9 & 2.95 & & \\
\hline
\end{tabular}


Table 3. (Continued).

\begin{tabular}{|c|c|c|c|c|c|c|c|c|c|c|c|c|c|}
\hline \multirow{4}{*}{$\begin{array}{c}\text { Sample } \\
\text { (core-section, } \\
\text { interval in } \mathrm{cm} \text { ) }\end{array}$} & \multirow{4}{*}{$\begin{array}{l}\text { Sub-bottom } \\
\text { depth } \\
\text { (m) }\end{array}$} & \multicolumn{6}{|c|}{ 2-min. GRAPE } & \multirow{2}{*}{\multicolumn{3}{|c|}{ Gravimetrics }} & \multirow{4}{*}{$\begin{array}{c}\text { Acoustic } \\
\text { impedance } \\
\left(\times 10^{5} \mathrm{~g} / \mathrm{cm}^{2} \mathrm{~s}\right) \\
\mathrm{V}^{\mathrm{a}}\end{array}$} & \multirow{4}{*}{$\begin{array}{l}\text { Shear } \\
\text { strength } \\
(\mathrm{kPa})\end{array}$} & \multirow{4}{*}{$\begin{array}{c}\text { Thermal } \\
\text { conductivity } \\
{\left[\times 10^{-3} \text { (cal/ }\right.} \\
\mathrm{cm} \cdot \mathrm{s} \cdot \text { deg) }\end{array}$} \\
\hline & & \multirow{2}{*}{\multicolumn{2}{|c|}{$\begin{array}{l}\text { Sonic } \\
\text { velocity } \\
(\mathrm{km} / \mathrm{s})\end{array}$}} & \multirow{2}{*}{\multicolumn{2}{|c|}{$\begin{array}{l}\text { Wet-bulk } \\
\text { density } \\
\left(\mathrm{g} / \mathrm{cm}^{3}\right)\end{array}$}} & \multirow{2}{*}{\multicolumn{2}{|c|}{$\begin{array}{c}\text { Porosity } \\
(\%)\end{array}$}} & & & & & & \\
\hline & & & & & & & & $\begin{array}{l}\text { Wet-bulk } \\
\text { density }\end{array}$ & & $\begin{array}{l}\text { Water } \\
\text { content }\end{array}$ & & & \\
\hline & & $\mathrm{H}^{\mathrm{a}}$ & $v^{a}$ & $\mathrm{H}^{\mathrm{a}}$ & $v^{a}$ & $\mathrm{H}^{\mathrm{a}}$ & $v^{a}$ & $\left(\mathrm{~g} / \mathrm{cm}^{3}\right)$ & $(\%)$ & & & & \\
\hline \multicolumn{14}{|l|}{ Hole 543 (Cont.) } \\
\hline $33-1,106-111$ & 306 & 1.785 & 1.681 & 1.43 & 1.52 & 75.8 & 70.4 & 1.62 & 57.3 & 36.3 & 2.72 & & \\
\hline $33-2,80-82$ & 307 & & & & & & & & & & & 33.4 & \\
\hline $33-3,22-26$ & 308 & 1.588 & 1.592 & 1.51 & 1.52 & 71.0 & 70.4 & 1.58 & 62.1 & 40.3 & 2.52 & & \\
\hline $33-3,63$ & 308 & & & & & & & & & & & & 2.339 \\
\hline $34-1,146-148$ & 316 & 1.683 & 1.661 & 1.49 & 1.36 & 72.2 & 80.0 & 1.54 & 61.6 & 40.9 & 2.56 & & \\
\hline $34-2,94-97$ & 317 & 1.776 & 1.711 & 1.47 & 1.48 & 73.4 & 72.8 & 1.61 & 59.3 & 37.7 & 2.75 & & \\
\hline $34, \mathrm{CC}$ & 324 & 2.426 & 2.453 & & & & & & & & & & \\
\hline \multicolumn{14}{|l|}{ Hole 543A } \\
\hline $\mathrm{H} 1-4,18-21$ & 327 & & & & & & & & & & & 119.4 & \\
\hline $2-1,8-11$ & 332 & 1.707 & 1.704 & 1.55 & 1.55 & 68.7 & & 1.66 & 57.2 & 35.4 & 2.83 & & \\
\hline $2-2,52-55$ & 334 & 1.589 & 1.569 & 1.52 & 1.60 & 70.4 & 65.7 & 1.61 & 63.7 & 40.6 & 2.53 & & \\
\hline $2, \mathrm{CC}$ & 342 & 1.638 & 1.624 & 1.58 & 1.63 & 66.9 & 63.9 & 1.64 & 59.2 & 36.9 & 2.66 & & \\
\hline $3-1,148-150$ & 343 & 1.749 & 1.689 & 1.66 & 1.67 & 62.1 & 61.5 & 1.74 & 55.9 & 33.0 & 2.94 & & \\
\hline $3-2,101-104$ & 344 & 1.706 & 1.674 & 1.81 & 1.57 & 53.1 & 67.5 & 1.73 & 58.3 & 34.6 & 2.90 & & \\
\hline $4-1,6-9$ & 351 & 1.690 & 1.646 & 1.79 & 1.88 & 54.3 & 49.0 & 1.79 & 55.2 & 31.5 & 2.95 & & \\
\hline $4-3,36-39$ & 354 & 1.689 & 1.566 & 1.63 & 1.81 & 63.9 & 53.1 & 1.80 & 55.6 & 31.7 & 2.98 & & \\
\hline $5-1,84-87$ & 361 & 1.662 & 1.636 & 1.30 & 1.74 & 83.6 & 57.3 & 1.76 & 56.6 & 32.9 & 2.88 & & \\
\hline $5-2,58-61$ & 363 & 1.686 & 1.651 & 1.81 & 1.78 & 53.1 & 54.9 & 1.77 & 56.6 & 32.7 & 2.92 & & \\
\hline $5-2,70-73$ & 363 & & & & & & & & & & & 128.5 & \\
\hline $6-1,49-52$ & 370 & 1.634 & 1.598 & 1.61 & 1.79 & 65.1 & 54.3 & 1.76 & 57.8 & 33.8 & 2.81 & & \\
\hline $6-1,66-68$ & 370 & & & & & & & & & & & 130.1 & \\
\hline $6-1,105$ & 371 & & & & & & & & & & & & 3.041 \\
\hline $7-1,96-100$ & 381 & 1.629 & 1.628 & 1.89 & 1.95 & 48.4 & 44.8 & 1.83 & 55.2 & 31.0 & 2.98 & & \\
\hline $7-1,101-104$ & 381 & & & & & & & & & & & 70.8 & \\
\hline $7-2,27-30$ & 381 & & & & & & & & & & & 73.7 & \\
\hline $7-3,91-94$ & 384 & & & & & & & & & & & 59.7 & \\
\hline $7-3,100-104$ & 384 & 1.697 & 1.672 & 2.06 & 1.91 & 38.2 & 47.2 & 1.94 & 48.4 & 25.6 & 3.24 & & \\
\hline $7-4,10$ & 384 & & & & & & & & & & & & 3.578 \\
\hline $8-1,10-13$ & 389 & & & & & & & & & & & 95.1 & \\
\hline $8-1,17-20$ & 389 & 1.610 & 1.586 & & & & & 1.76 & 56.4 & 32.9 & 2.79 & & \\
\hline $8-1,87-91$ & 390 & 1.638 & 1.587 & & & & & 1.78 & 56.5 & 32.5 & 2.82 & & \\
\hline $8, \mathrm{CC}(5-8)$ & 399 & & & & & & & & & & & 114.9 & \\
\hline $9-1,6-10$ & 399 & 1.617 & 1.597 & & & & & 1.80 & 54.8 & 31.1 & 2.87 & & \\
\hline $9-1,33-36$ & 399 & & & & & & & & & & & 74.5 & \\
\hline $9-1,50-54$ & 399 & 1.568 & 1.585 & & & & & 1.81 & 54.6 & 30.9 & 2.87 & & \\
\hline $10-1,14-17$ & 408 & & & & & & & & & & & 71.7 & \\
\hline $10-1,28-32$ & 408 & 1.664 & 1.671 & & & & & 1,85 & 52.3 & 28.9 & 3.09 & & \\
\hline $10-1,120-124$ & 409 & 4.910 & 4.932 & 2.74 & 2.72 & & & 2.65 & 8.5 & 3.3 & 13.07 & & \\
\hline $11-2,30-34$ & 419 & 5.621 & 5.561 & 2.96 & 2.97 & & & 2.81 & 5.6 & 2.1 & 15.57 & & \\
\hline $12-1,80-84$ & 421 & 5.358 & 5.287 & 2.99 & 2.90 & & & 2.80 & 6.1 & 2.2 & 14.80 & & \\
\hline $13-3,55-58$ & 431 & 5.580 & 5.314 & 3.06 & 3.06 & & & 2.83 & 5.7 & 2.1 & 15.04 & & \\
\hline $15-3,7-11$ & 441 & 5.293 & 5.284 & 3.02 & 2.91 & & & 2.8 & 4.5 & 1.6 & 14.90 & & \\
\hline $16-3,46-50$ & 449 & 5.471 & 5.327 & 3.06 & 2.97 & & & 2.82 & 4.6 & 1.7 & 15.02 & & \\
\hline
\end{tabular}

Note: Some shear strength measurements exceeded instrumentation limits and are indicated by a greater than $(>)$ symbol. These values are not plotted in any figures and the values are considered below failure strength of the material.

${ }^{\mathrm{a}} \mathrm{H}=$ horizontal; $\mathrm{V}=$ vertical.

Table 4. Average sonic velocities, in Holes 543 and 543A.

\begin{tabular}{ccccccc}
\hline $\begin{array}{c}\text { Sub-bottom } \\
\text { depth range } \\
(\mathrm{m})\end{array}$ & $\begin{array}{c}\bar{V}_{\|}{ }^{\mathrm{a}} \\
(\mathrm{km} / \mathrm{sec})\end{array}$ & $\mathrm{S}$ & $\mathrm{N}$ & $\begin{array}{c}\bar{V}_{\frac{1}{}}{ }^{\mathrm{a}} \\
(\mathrm{km} / \mathrm{sec})\end{array}$ & $\mathrm{S}$ & $\mathrm{N}$ \\
\hline $0-100$ & 1.494 & 0.021 & 25 & 1.495 & 0.021 & 29 \\
$100-200$ & 1.533 & 0.037 & 16 & 1.544 & 0.051 & 18 \\
$200-300$ & 1.624 & 0.055 & 21 & 1.610 & 0.066 & 21 \\
$300-400$ & 1.703 & 0.176 & 21 & 1.676 & 0.183 & 21 \\
Total & 1.589 & 0.135 & 86 & 1.580 & 0.120 & 86 \\
\hline
\end{tabular}

Note: Values listed here are exclusive of measurements in basement. $\bar{V}_{\|}=$velocity parallel to bedding; $\bar{V}_{\perp}=$ velocity perpendicular to bedding. $\mathrm{S}=$ standard deviation and $\mathrm{N}=$ number of samples.

${ }^{a}$ Includes $V_{\|}$presumed to be equal to $V_{\perp}$ in the upper section of semiconsolidated material. the site, but below the gap in data, the density has increased significantly and averages about 1.70 to $1.75 \mathrm{~g} /$ $\mathrm{cm}^{3}$. There is a slight decrease in density from about 260 to $340 \mathrm{~m}$ sub-bottom.

The porosity and water content values for the upper $200 \mathrm{~m}$ of Site 543 are quite variable, often decreasing or increasing up to $20 \%$ in a few tens of meters. Similar trends in the variation in density can be noted in the upper $200 \mathrm{~m}$ of Site 543 (Fig. 8). Below the gap in data near $200 \mathrm{~m}$, both the water content and porosity decrease gradually toward the bottom of the hole, as might be expected due to increasing compaction and overburden pressure.

We should note here that there is a great deal more scatter in the water content, porosity, and density values 
Table 5. Calculated sonic velocity anisotropy values for individual samples, Site 543 (see text for derivation).

\begin{tabular}{|c|c|c|}
\hline $\begin{array}{c}\text { Section } \\
\text { (core-section) }\end{array}$ & $\begin{array}{l}\text { Sub-bottom } \\
\text { depth } \\
\text { (m) }\end{array}$ & $\begin{array}{c}\text { Anisotropy } \\
(\%)\end{array}$ \\
\hline \multicolumn{3}{|l|}{ Hole 543} \\
\hline $8-4$ & 73 & -0.17 \\
\hline $9-4$ & 82 & -0.30 \\
\hline $10-4$ & 92 & 0.0 \\
\hline $11-3$ & 100 & -0.88 \\
\hline $12-2$ & 108 & 0.27 \\
\hline $12-6$ & 114 & -0.34 \\
\hline $13-2$ & 118 & -0.20 \\
\hline $13-6$ & 123 & 0.30 \\
\hline $14-2$ & 127 & 0.26 \\
\hline $14-5$ & 132 & -5.12 \\
\hline $16-2$ & 146 & -0.23 \\
\hline $16-4$ & 148 & 1.47 \\
\hline $17-4$ & 159 & 0.43 \\
\hline $18-1$ & 163 & 0.51 \\
\hline $18-6$ & 171 & 0.19 \\
\hline $19-3$ & 176 & 1.01 \\
\hline $20-2$ & 184 & 0.16 \\
\hline $20-3$ & 186 & 0.36 \\
\hline $23-1$ & 211 & 1.22 \\
\hline $23-2$ & 213 & -0.03 \\
\hline $24-2$ & 222 & 0.10 \\
\hline $24-4$ & 225 & -0.10 \\
\hline $25-1$ & 229 & 1.25 \\
\hline $25-2$ & 231 & 0.19 \\
\hline $26-2$ & 241 & 2.00 \\
\hline $26-5$ & 245 & 1.57 \\
\hline $27-3$ & 252 & 0.46 \\
\hline $27-5$ & 255 & 0.03 \\
\hline $28-1$ & 258 & 0.22 \\
\hline $28-3$ & 261 & 1.20 \\
\hline $29-2$ & 269 & 0.80 \\
\hline $29-3$ & 271 & 0.40 \\
\hline $30-2$ & 279 & -0.47 \\
\hline $30-5$ & 284 & -0.21 \\
\hline $30-6$ & 285 & 1.51 \\
\hline $31-1$ & 287 & -0.09 \\
\hline $31-2$ & 288 & -0.80 \\
\hline $32-1$ & 296 & 2.09 \\
\hline $32-4$ & 300 & -1.93 \\
\hline $33-1$ & 306 & -3.00 \\
\hline $33-3$ & 308 & -0.13 \\
\hline $34-1$ & 316 & 0.66 \\
\hline $34-2$ & 317 & 1.86 \\
\hline $34, \mathrm{CC}$ & 324 & -0.55 \\
\hline \multicolumn{3}{|l|}{ Hole $543 \mathrm{~A}$} \\
\hline $2-1$ & 332 & 0.09 \\
\hline $2-2$ & 334 & 0.63 \\
\hline $2, \mathrm{CC}$ & 342 & 0.43 \\
\hline $3-1$ & 343 & 1.75 \\
\hline $3-2$ & 344 & 0.95 \\
\hline $4-1$ & 351 & 1.32 \\
\hline $4-3$ & 354 & 1.02 \\
\hline $5-1$ & 361 & 0.79 \\
\hline $5-2$ & 363 & 1.05 \\
\hline $6-1$ & 370 & 1.11 \\
\hline $7-1$ & 381 & 0.03 \\
\hline $7-3$ & 384 & 0.74 \\
\hline $8-1$ & 389 & 0.75 \\
\hline $8-1$ & 390 & 1.58 \\
\hline $9-1$ & 399 & 0.62 \\
\hline $9-1$ & 399 & -0.54 \\
\hline $10-1$ & 408 & -0.21 \\
\hline
\end{tabular}

for the upper $200 \mathrm{~m}$ at Site 543 than for strata drilled at equivalent depths at Sites 541 and 542.

\section{Shear Strength}

Shear strength values for cores From Site 543 are listed in Table 3 and are shown in Figures 8 and 4. Unlike shear strengths measured at Sites 541 and 542, the values obtained at Site 543 are quite scattered and variable throughout the drilled section, although the average shear strength values tend to increase down the hole. The scattered data points, especially at depth, for shear strength are very unlike the generally constant (or slightly decreasing), uniform values measured at the other two sites. The difference in data suggests that consolidation or tectonic processes that may be active at Sites 541 and 542 are apparently not currently active at Site 543 , or that some other processes are acting on the strata at Site 543.

\section{Thermal Conductivity}

Eight conductivity measurements were made at Site 543 (Table 3). The conductivity values measured at site 543 are generally slightly less (about $10 \%$ ) than values measured for equivalent depths at Sites 541 and 542 . Conductivity is nearly constant at Site 543 and averages about $2.5 \times 10^{-3} \mathrm{cal} / \mathrm{cm} \cdot \mathrm{s} \cdot \mathrm{deg}$, except near the bottom of the hole, where conductivity values increase to slightly more than $3.5 \times 10^{-3} \mathrm{cal} / \mathrm{cm} \cdot \mathrm{s} \cdot \mathrm{deg}$.

\section{Some Related Findings}

Figure 9 is a plot of porosity versus density measurements from cores taken at Site 543. Also shown is the empirically derived equation from DSDP, relation density and porosity:

$$
\rho_{\mathrm{b}}=2.70-1.675 \phi
$$

where $\phi=$ porosity of a sample.

The porosity and density values from Site 543 are scattered but do show a generally linear relationship. However, the scatter in the data from Site 543 is considerably greater than density-porosity data from Sites 541 and 542. Data from Sites 541 and 542 consistently plot above the empirically derived function from DSDP, whereas data from Site 543 generally plot below the DSDP equation. Thus for a given porosity, strata from Sites 541 and 542 are generally more dense than equivalent rocks from Site 543 .

Earlier, we speculated that the uniform physical properties observed at sites 541 and 542 in a so-called subduction zone may be related to a tectonic overprint. Convergence and subsequent deformation have apparently allowed a relatively irregular physical property profile, as at Site 543, to be transformed to a uniform profile, as at Sites 541 and 542.

\section{PALEOMAGNETICS}

The objectives for paleomagnetic sampling at Site 543 were to use polarity stratigraphy for age control and to determine the magnetic properties of the basalts. Refer to the paleomagnetism chapter (Wilson, this volume) 


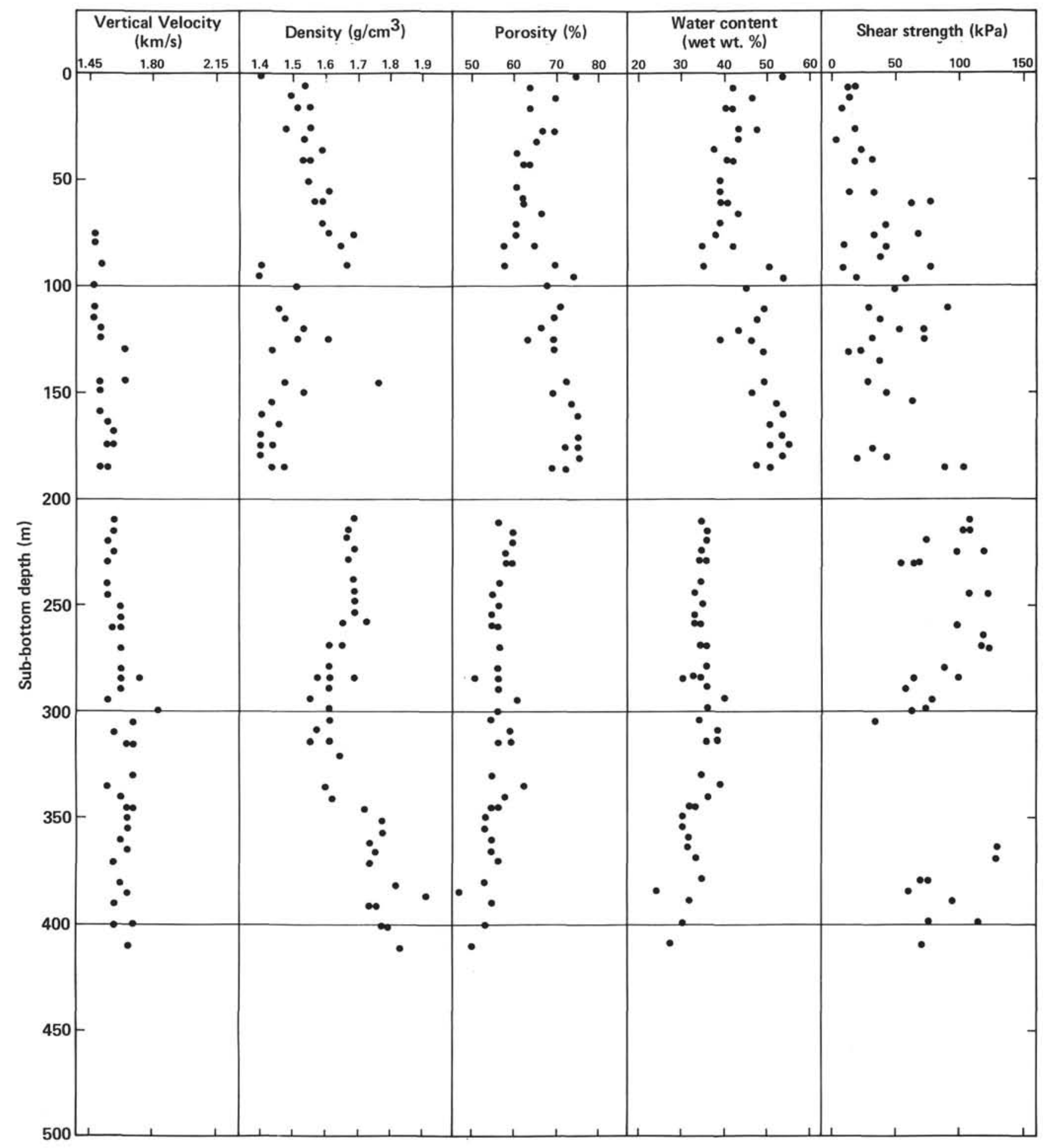

Figure 8. Plot of water content (wet wt. \%), porosity $(\%)$, density $\left(\mathrm{gm} / \mathrm{cm}_{3}\right)$, vertical velocity $(\mathrm{km} / \mathrm{s})$, and shear strength $(\mathrm{kPa})$ values versus depth at Site 543 .

for a complete discussion. Drilling deformation was, again, a major problem in the upper part of the sedimentary section. No samples at all were collected in the interval from Cores 1 to 5 , and samples were very sparse from Cores 6 to 16 - completely inadequate for polarity stratigraphy. Sample density and stability were adequate for Cores 17 to 20 (161-199 m sub-bottom).
The reversed intervals in Cores 18 and 20 should correlate to polarity epochs 16 and 18, respectively (Fig. 10). The radiolarian dates for this range strongly support these identifications, based on the correlation of Theyer and Hammond (1974).

The correlation between core polarity epochs and the marine magnetic anomalies is not rigorous in this inter- 


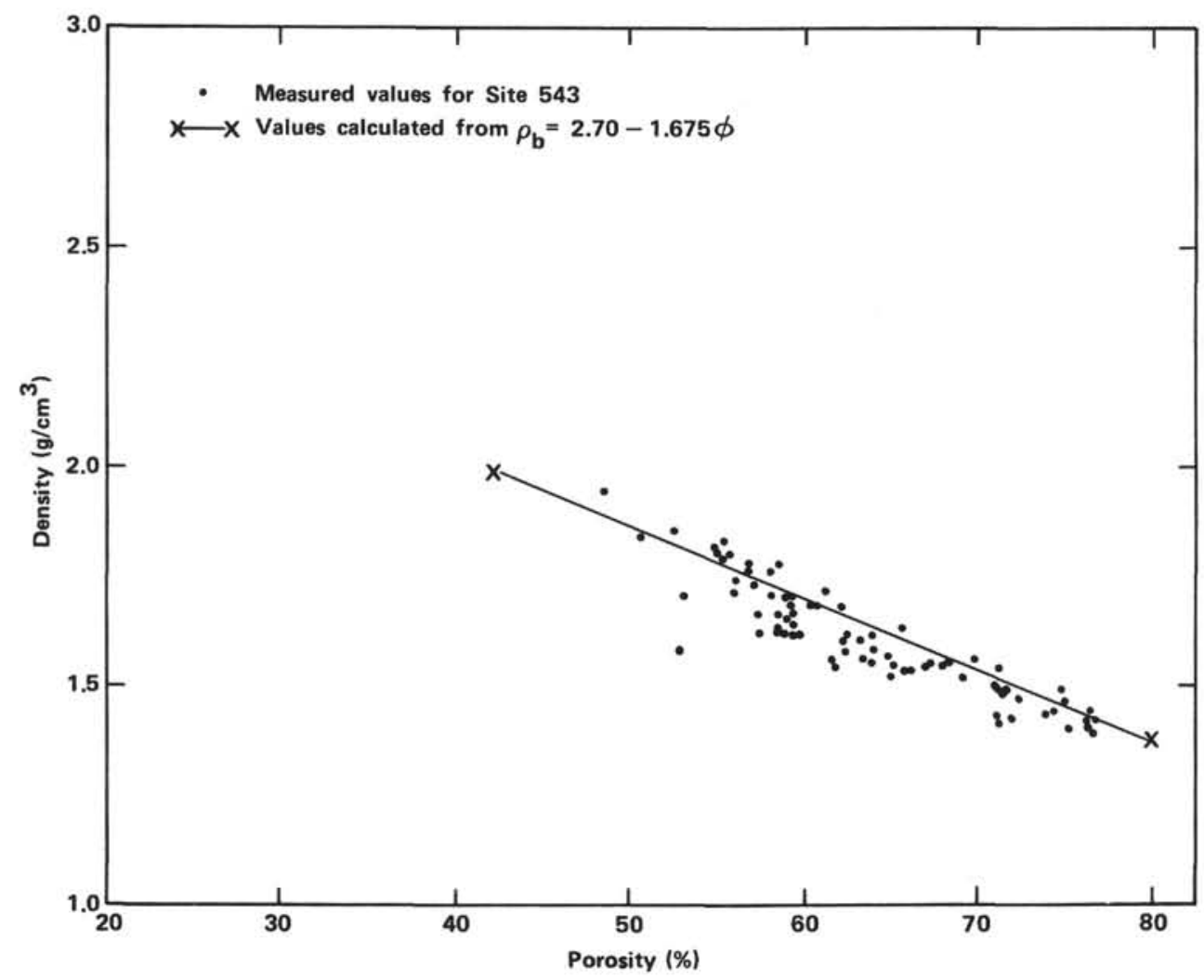

Figure 9. Plot of density versus porosity for core samples from Site 543. (See text for discussion.)

val, but if we have a nearly constant sedimentation rate, these four cores would correspond very nicely to Marine Anomalies 5C and 5D (age range 16 to $18 \mathrm{Ma}$, from Ness et al., 1980).

Cores 24 to 34 present an interesting problem. Drilling deformation was minimal and recovery was good, so sample density was adequate. Of over 40 samples, more than 30 are confidently judged to be reversed, and only one is normal. This pattern is not remotely compatible with any time scale and indicates remagnetization during a predominantly reversed interval. There is little hope for drawing any useful conclusions from the sediments in Hole 543A due to poor recovery and low paleolatitude.

The basalts are extremely stably magnetized and show very good internal consistency. NRM intensities are fairly strong, generally 5 to $10 \AA / \mathrm{m}$. Directions change less than $2^{\circ}$ with $\mathrm{AF}$ demagnetization, and median destructive fields are 15 to $30 \mathrm{nT}$. Inclinations divide neatly into three groups: Section 543A-10-1, $-11^{\circ}$; Sections 543A$11-1$ to $543 \mathrm{~A}-12-1,-35^{\circ} \pm 1^{\circ}$; and Sections 543A-12-2 to $543 \mathrm{~A}-16-7,25^{\circ} \pm 4^{\circ}$. These correspond to basalts of differing petrography and composition, hence probably represent separate eruptions that recorded secular variation during a single reversed polarity epoch (Natland, this volume; Wilson, this volume).

\section{TEMPERATURE MEASUREMENTS}

A temperature logging run was made in Hole 543A using the Gearhart-Owen logging tool. The run extended past the end of the pipe, but stopped short of base- ment due to bridging in the hole. The results, complicated by an upward flow of warm water from the bottom of the hole, suggest a smaller undisturbed thermal gradient (roughly $20^{\circ} / \mathrm{km}$ ) than that found to the west of the deformation front at Site 541. For more details, see Davis et al. (this volume).

\section{SEISMIC STRATIGRAPHY-CORRELATIONS WITH LITHOLOGY AND PHYSICAL PROPERTIES}

In the abyssal plain north of the Tiburon Rise the A1C seismic section is characterized by flat or gently dipping, more or less continuous reflectors of low amplitude and generally low continuity. Nevertheless it is possible to define several units within the sequence.

Seismic unit 1 occurs between seafloor and Reflector 1 and is composed of flat-lying layered sediments passing westward into the toe of the Barbados Ridge complex. Note in profile A1C that the uppermost part of this unit could be slightly folded at the deformation front (Fig. 3).

Seismic unit 2 occurs between Reflectors 1 and 2, is relatively transparent, and shows few thickness variations. This unit passes below the discontinuously reflective sequence of the prism.

Seismic unit 3 occurs between Reflectors 2 and 3 (the top of the acoustic basement) and exhibits rapid variation of thickness due to the paleotopography as well as variations in seismic character.

The location of Site 543 was chosen over a basement high, between the deformation front and the proposed 


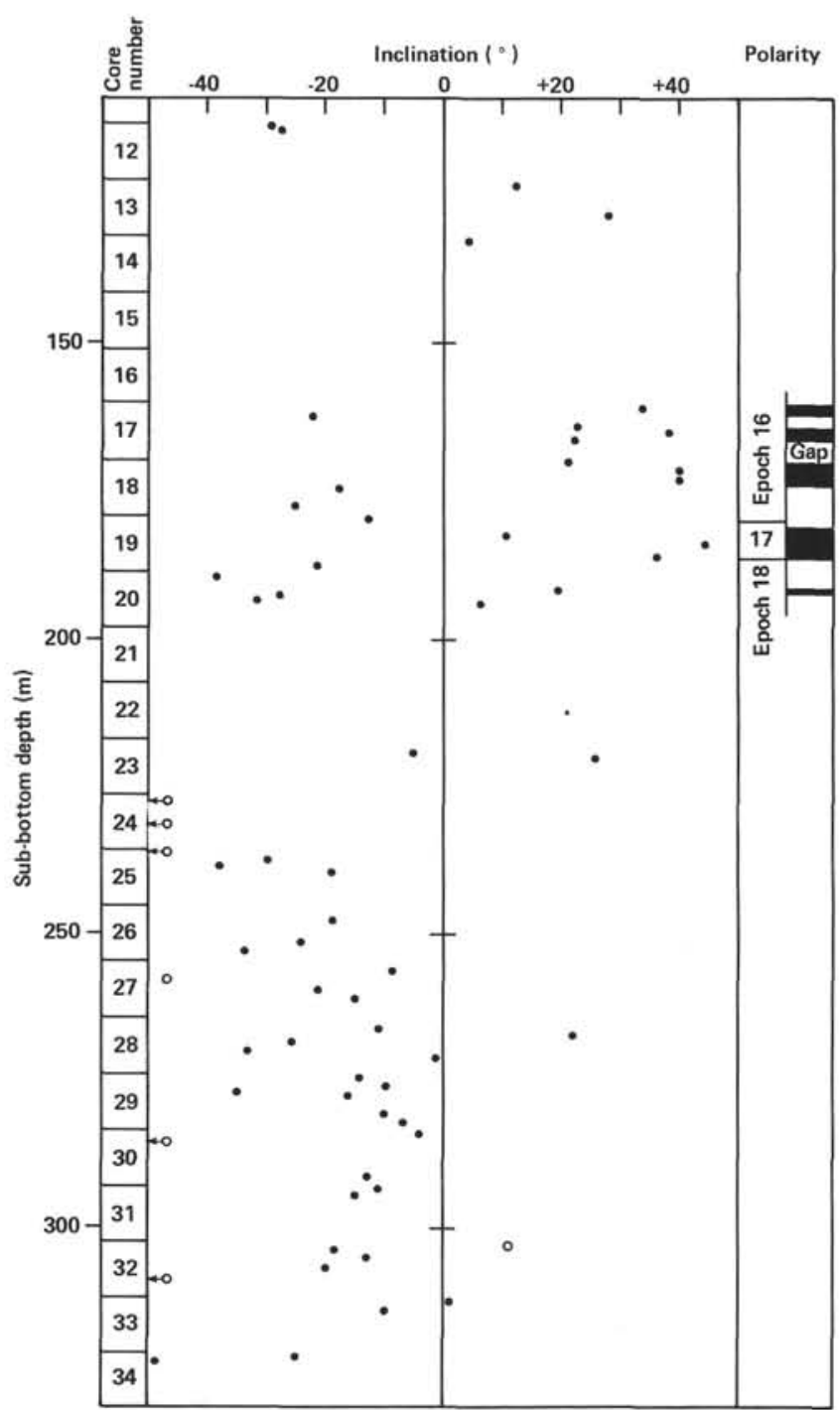

Figure 10. Stable magnetic inclination in sediments of Hole 543 versus sub-bottom depth, and polarity interpretation. (Black areas indicate normal polarity; white areas show reversed polarity. Open circles represent data judged to be less reliable than the data represented by filled circles; open circles with arrows indicate data that are off the graph.)

reference hole (CAR-1D). Due to navigational difficulties the location of Site 543 is estimated to be $0.5 \mathrm{~km}$ north of the Profile A1C (Fig. 2). At shot point 380 on Profile A1C the sedimentary sequence is $0.490 \mathrm{~s}$ thick (two-way traveltime), where seismic unit 1 is $220 \mathrm{~m} / \mathrm{s}$ thick, seismic unit 2 is $150 \mathrm{~m} / \mathrm{s}$ thick, and seismic unit 3 is $120 \mathrm{~m} / \mathrm{s}$ thick.

Despite the southern displacement of Profile A1C from Site 543, correlation between the observed seismic stratigraphy and the drilled section is good (Fig. 11):

1) From 0 to $174 \mathrm{~m}$ (sub-bottom), the well-layered Pleistocene-Pliocene-upper Miocene sequence (Lithological Units 1, 2, and 3) corresponds to seismic unit 1 (using an average velocity of $1.57 \mathrm{~km} / \mathrm{s}$, the thickness of this seismic unit should be about $173 \mathrm{~m}$ ). We can correlate the prominent Reflector 1 with the significant decrease in porosity and increase in density and shear strength, which occurs between 180 and $200 \mathrm{~m}$ sub-bottom at the uppermost part of the lower Miocene radiolarian muds; the same Reflector 1 was penetrated at Site 541 , where the bit entered the very top of the underthrust sequence.

2) From $174 \mathrm{~m}$ to the bottom of Hole 543, Lithological Units 4, 5, and 6 correspond to seismic units 2 and 3 . A lack of significant change in the physical properties of the cored section in unit 2 makes it difficult to correlate the seismic stratigraphy with the cored section. Nevertheless, using a velocity of $1.68 \mathrm{~km} / \mathrm{s}$ between 200 and $300 \mathrm{~m}$, we can correlate Reflector 2 at the bottom of seismic unit 2 to the top of zeolitic clays (Unit $5 b$ ) of the middle Eocene.

3) The depth to oceanic layer 2 at Site 543 was difficult to predict because of the lack of good velocity analyses from seismic reflection data. The cored contact is estimated at $411 \mathrm{~m}$ sub-bottom, a depth close to the calculated depth $(404 \mathrm{~m})$ based on core velocity measurements (around $390 \mathrm{~m}$ using an average velocity of 1.75 $\mathrm{km} / \mathrm{s}$ ).

\section{SUMMARY AND CONCLUSIONS}

Site 543 is located on the Tiburon Rise $3.5 \mathrm{~km}$ seaward of the deformation front of the Barbados Ridge complex. Here we penetrated a 411-m sequence of hemipelagic and pelagic sediments and $44 \mathrm{~m}$ of basaltic basement.

The recent sediments consist of ashy mud to a depth of $8 \mathrm{~m}$ at Site 543 . The subjacent sediments to $70.5 \mathrm{~m}$ are Pleistocene to upper Pliocene ashy nannofossil mud that is transitional to a unit of lower Pliocene to lower Miocene mud and ashy mud that extends to $176 \mathrm{~m}$ subbottom. Radiolarian clay initially with local ash layers, subsequently with manganese stains, occurs from 170 to $322 \mathrm{~m}$ sub-bottom, spanning the lower Miocene into the Oligocene. Zeolitic clay-claystone is present from 322 to $379 \mathrm{~m}$ sub-bottom and overlies a basal calcareous, ferruginous Maestrichtian to Campanian claystone that contacts basalt at $411 \mathrm{~m}$. Plagioclase as well as plagioclaseolivine phyric pillow basalts extend to a total depth of $455 \mathrm{~m}$.

Overall the lithology at Site 543 records the birth and evolution of an oceanic crustal sequence with its progressive juxtaposition with an active volcanic source. The pillow basalts recovered at the base of Site 543 are typical of those found at the Mid-Atlantic Ridge, and they are succeeded by altered sediments commonly formed during hydrothermal activity at ridges. The claystones and zeolitic clay-claystone and manganese-rich radiolarian clays record slow sedimentation under openocean conditions, removed from any significant terrigenous or volcanic source. Notable quantities of ash occur in the lower Miocene and are also present through the Neogene, suggesting proximity to the Lesser Antilles arc. The carbonate content and occurrence of nannofossils and foraminifers suggest that Site 543 was above the CCD in the Late Cretaceous and the early Pliocene to Pleistocene. In general the Miocene and younger sediments at Site 543 are similar to those cored at Sites 541 and 542 . 


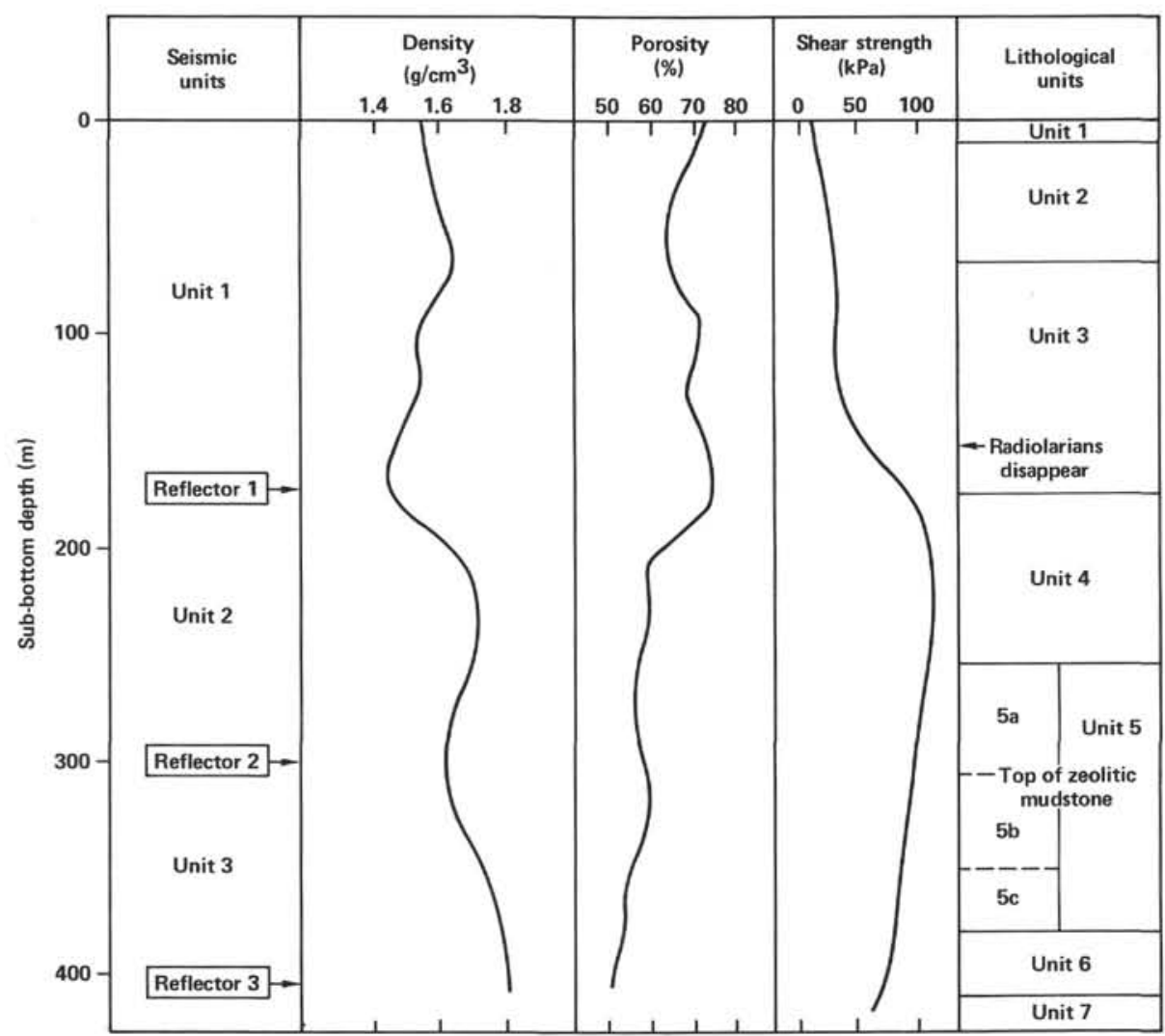

Figure 11. Correlations between physical properties, lithological units, and main reflectors of profile A1C (Fig. 3).

The structural features observed in the cores from Site 543 are principally induced by drilling. As such, these features provide an excellent reference section and allow separation of drilling induced and natural structures in the tectonically deformed sequences at Sites 541 and 542. Notably, the clay-rich sediments above $191 \mathrm{~m}$ and below 315 to $380 \mathrm{~m}$ at Site 543 are more easily deformed by drilling than the radiolarian-bearing sediments separating them, suggesting the former may constitute favored zones for décollement when this oceanic section is underthrust beneath the trench slope.

At Site 543 sonic velocity increased uniformly with depth in the sedimentary section. Density and porosity show a sharp increase and decrease, respectively, between 180 and $200 \mathrm{~m}$. An increase in shear strength also occurs at this interval. This marked variation in physical properties correlates with the transition from mud to radiolarian mudstone and the approximate seaward extension of the reflector separating the apparently offscraped and underthrusted units to the west.

A key characteristic of Site 543 is the overall equivalence of its Miocene and younger sediments to the sequences cored at Sites 541 and 542; as such, we may infer oceanic derivation and offscraping of the deformed and faulted sequence penetrated at these latter sites. A second critical result is the association between 165 and $200 \mathrm{~m}$ of the top of the radiolarian-bearing mud, the increase in density and strength, and the reflection separating the apparently offscraped and subducted units west of the deformation front. The observed changes in physical properties, while subtle, favor the development of a décollement at this level, as inferred from the seismic data.

A downhole seismometer with temperature and tilt recorders was emplaced in the basaltic basement at Site 543. The instrument remained in the hole while a seismic refraction experiment was conducted. Malfunctioning of the seismometer necessitated retrieval of the downhole instrument and prevented deployment of the longterm recording package on the seafloor.

\section{REFERENCES}

Berger, W. H., 1977. Carbon dioxide excursion and the deep-sea record, aspects of the problem. In Anderson, N. R., and Malahoff, A. (Eds.), The Fate of Fossil Fuel $\mathrm{CO}_{2}$ in the Oceans. Mar. Sci., 6: 505-542.

Berggren, W. A., 1973. The Pliocene time scale: calibration of planktonic foraminiferal and calcareous nannoplankton zones. Nature, 243:391-397.

Biju-Duval, B., Mascle, A., Montadert, L., and Wanneson, J., 1978. Seismic investigations in the Columbia, Venezuela, and Grenada Basins, and on the Barbados Ridge for future IPOD drilling. Geol. Mijnbouw, 57:105-116.

Blow, W. H., 1969. Late middle Eocene to Recent planktonic foraminiferal biostratigraphy. In Bronnimann, P., and Renz, H. H. (Eds.), Proc. First Int. Conf. Planktonic Microfossils, Geneva, 1967. 1: 199-422.

Bukry, D., and Okada, H., 1980. Supplementary modification and introduction of code numbers to the low-latitude Coccolith biostratigraphic zonation. Mar. Micropaleontol., 5:321-325.

Gartner, S., 1977. Calcareous nannofossil biostratigraphy and revised zonation of the Pleistocene. Mar. Micropaleontol., 2:1-25.

Mascle, A., Lajat, D., and Nely, G., in press. Sediment deformation linked to subduction and argilokinesis in the southern Barbados 
Ridge from multichannel seismic surveys. Trans. 4th Latin Am. Geol. Congr.

Ness, G., Levi, S., and Couch, R., 1980. Marine magnetic anomaly time scales for the Cenozoic and Late Cretaceous: a precis, critique, and synthesis. Rev. Geophys. Space Phys., 18:753-770.

Riedel, W. R., and Sanfilippo, A., 1978. Stratigraphy and evolution of tropical Cenozoic radiolarians. Micropaleontology, 23:61-69.
Sanfilippo, A., and Riedel, W. R., 1982. Revision of the radiolarian genera Theocotyle, Theocotylissa, and Thyrsocyrtis. Micropaleontology, 28(2):170-188.

Theyer, F., and Hammond, S. R., 1974. Paleomagnetic polarity sequence and radiolarian zones, Brunhes to Polarity Epoch 20. Earth Planet. Sci. Lett., 22:307-319.

Verbeek, J. W., 1976. Calcareous nannoplankton biostratigraphy of Middle and Upper Cretaceous deposits in Tunisia, Southern Spain, and France. Utrecht Micro. Bull., 16:1-157. 

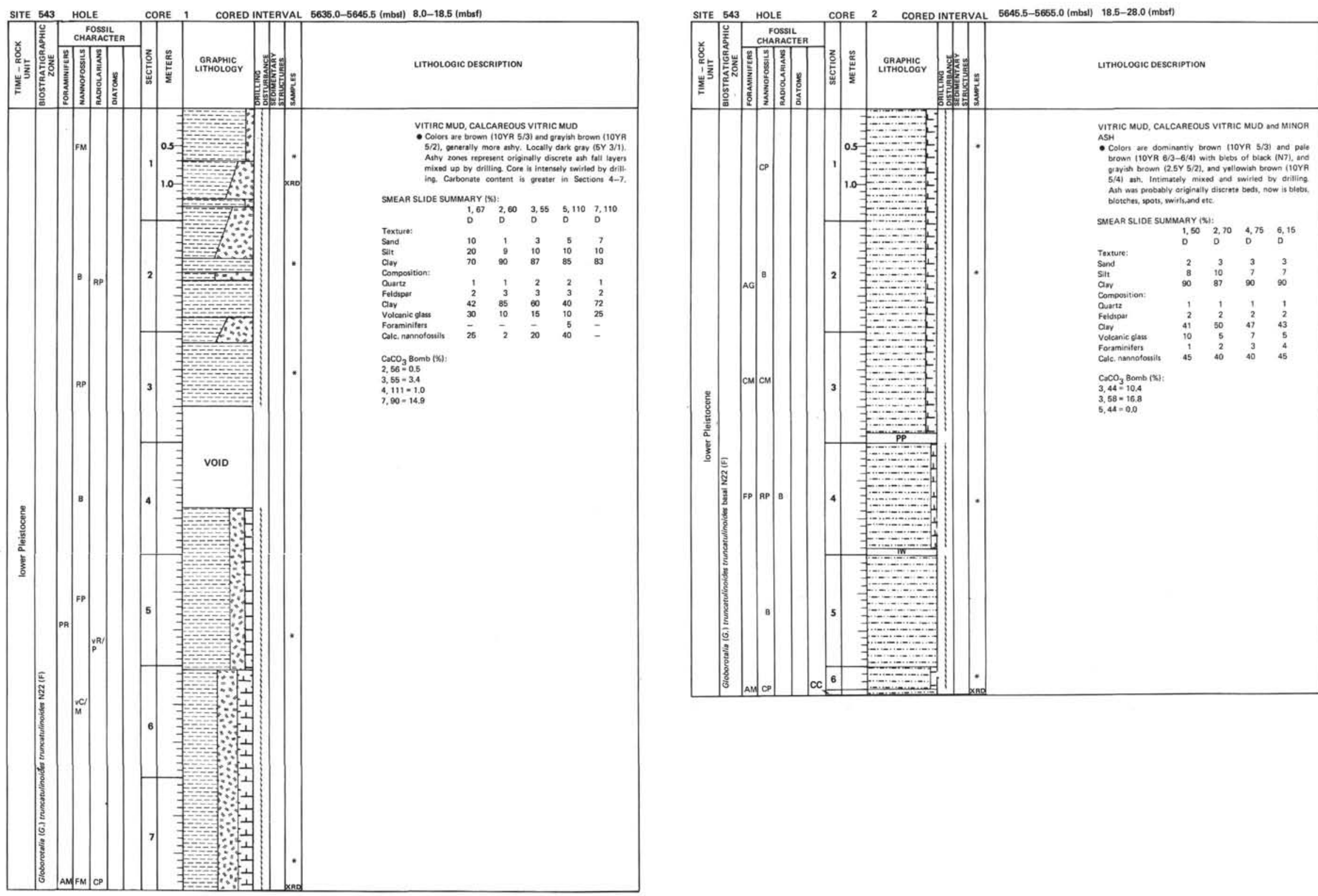
SITE 543 HOLE CORE 3 CORED INTERVAL $5655.0-5664.5$ (mbs) $28.0-37.5$ (mbsf)

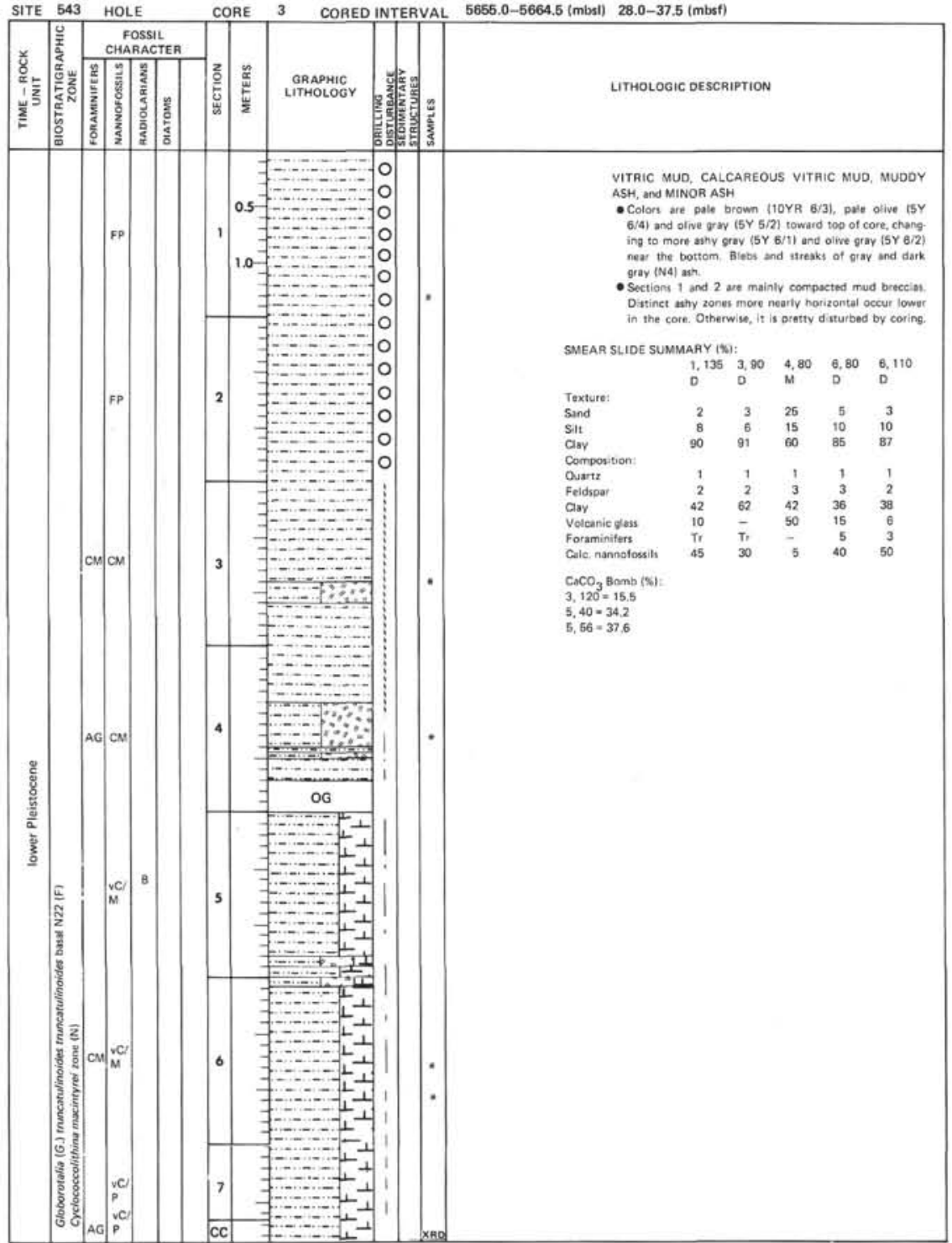

SITE 543 HOLE CORE 4 CORED INTERVAL 5664.5-5674.0 (mbs) 37.5-47.0 (mbst)

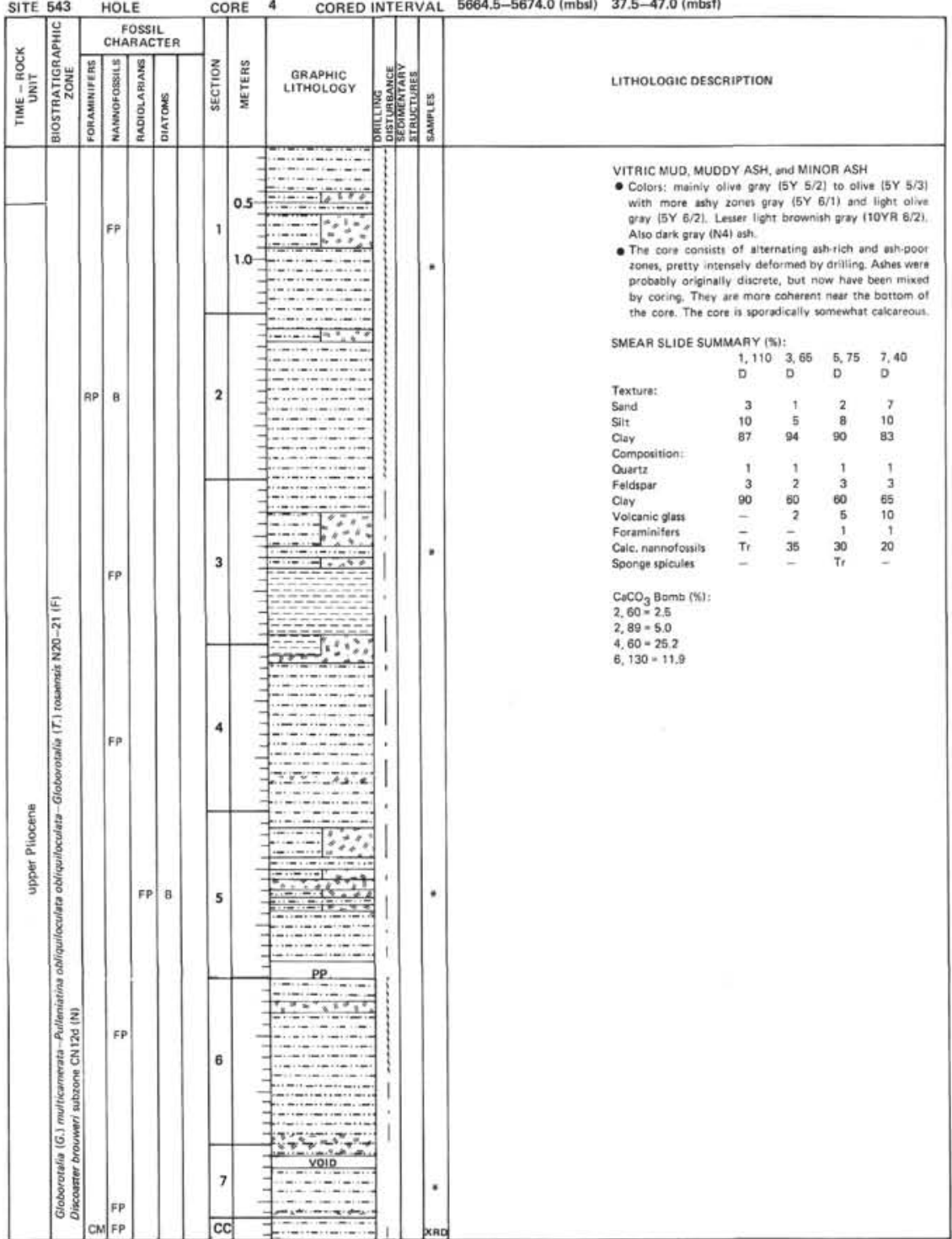



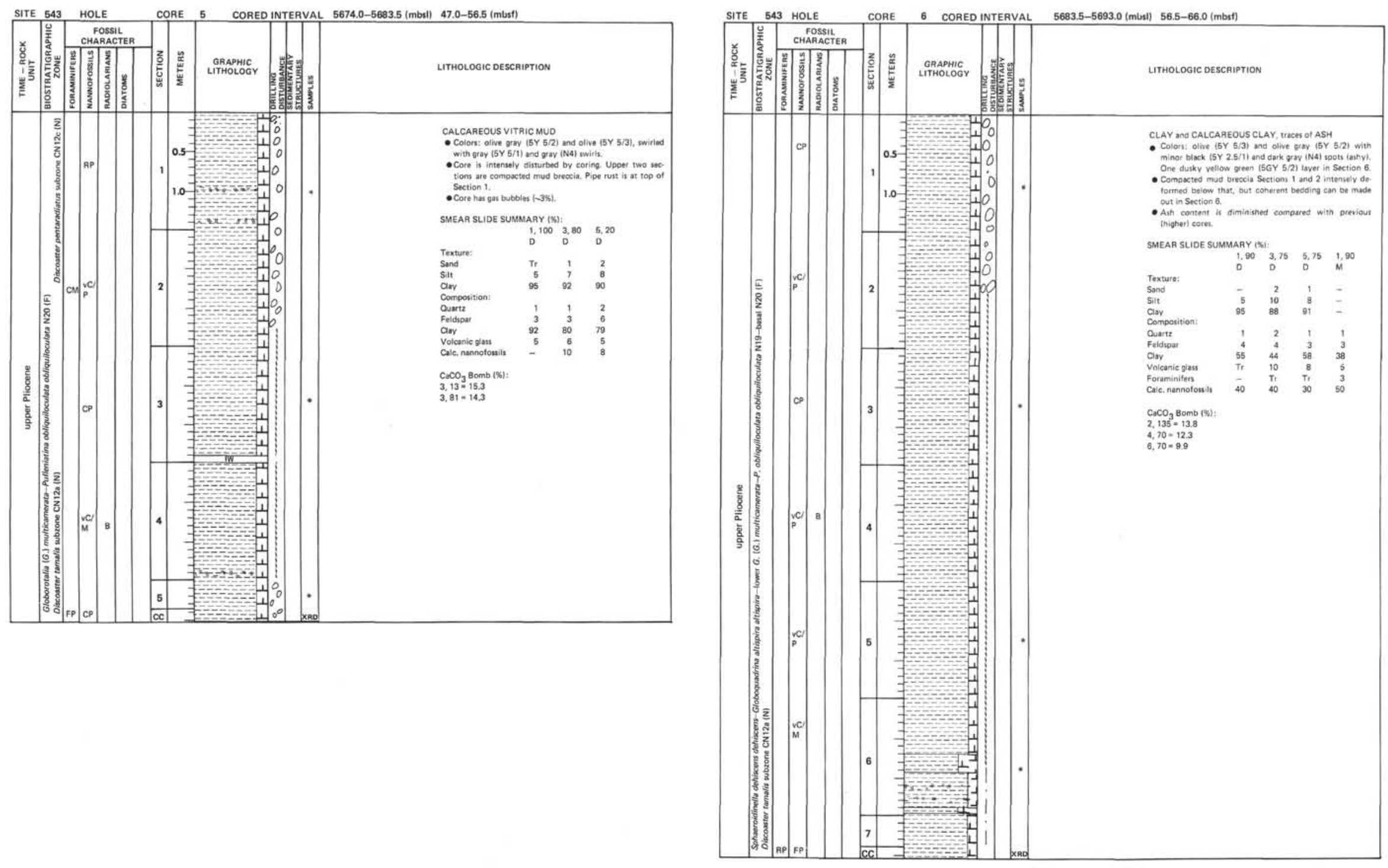

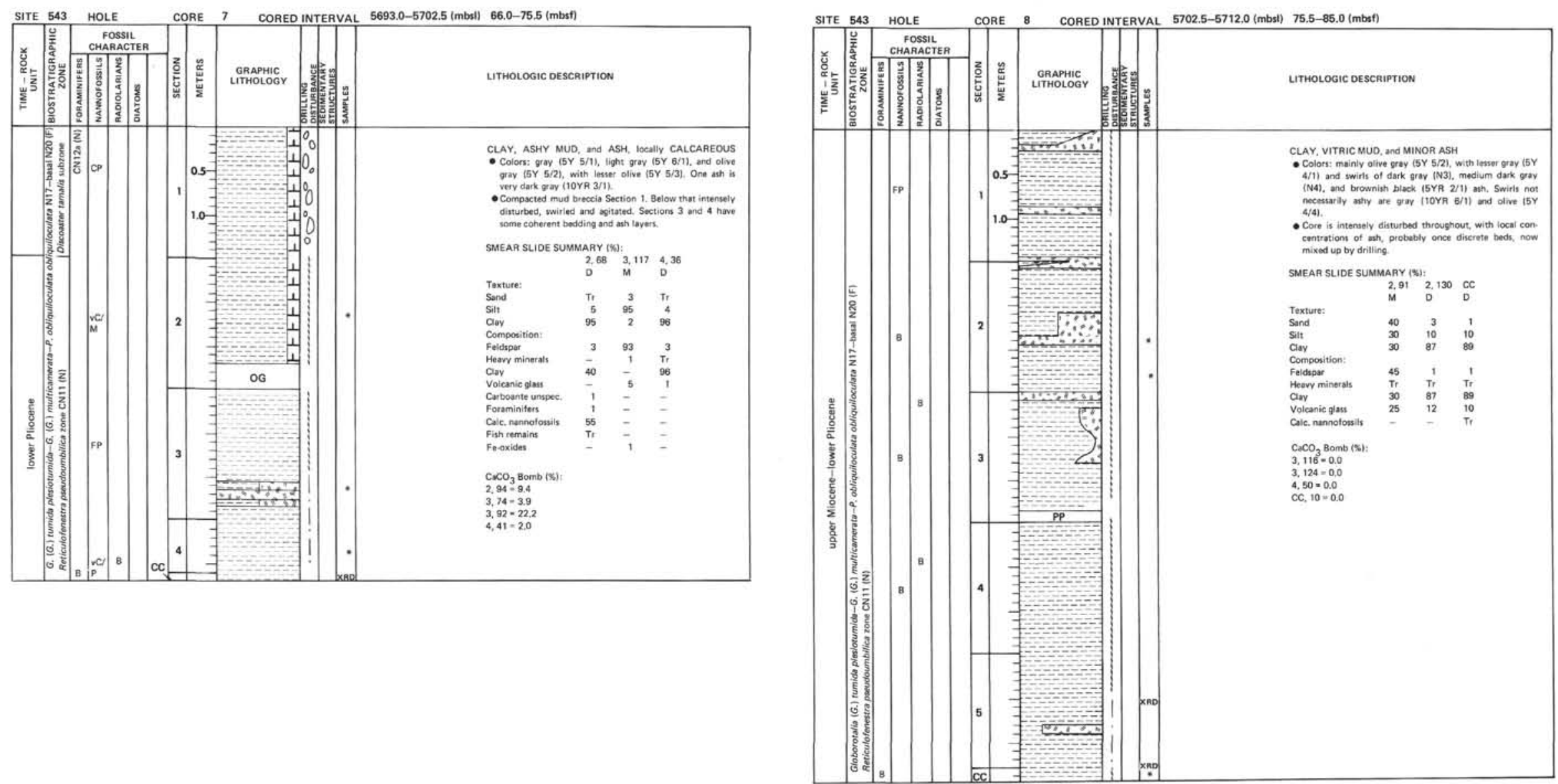


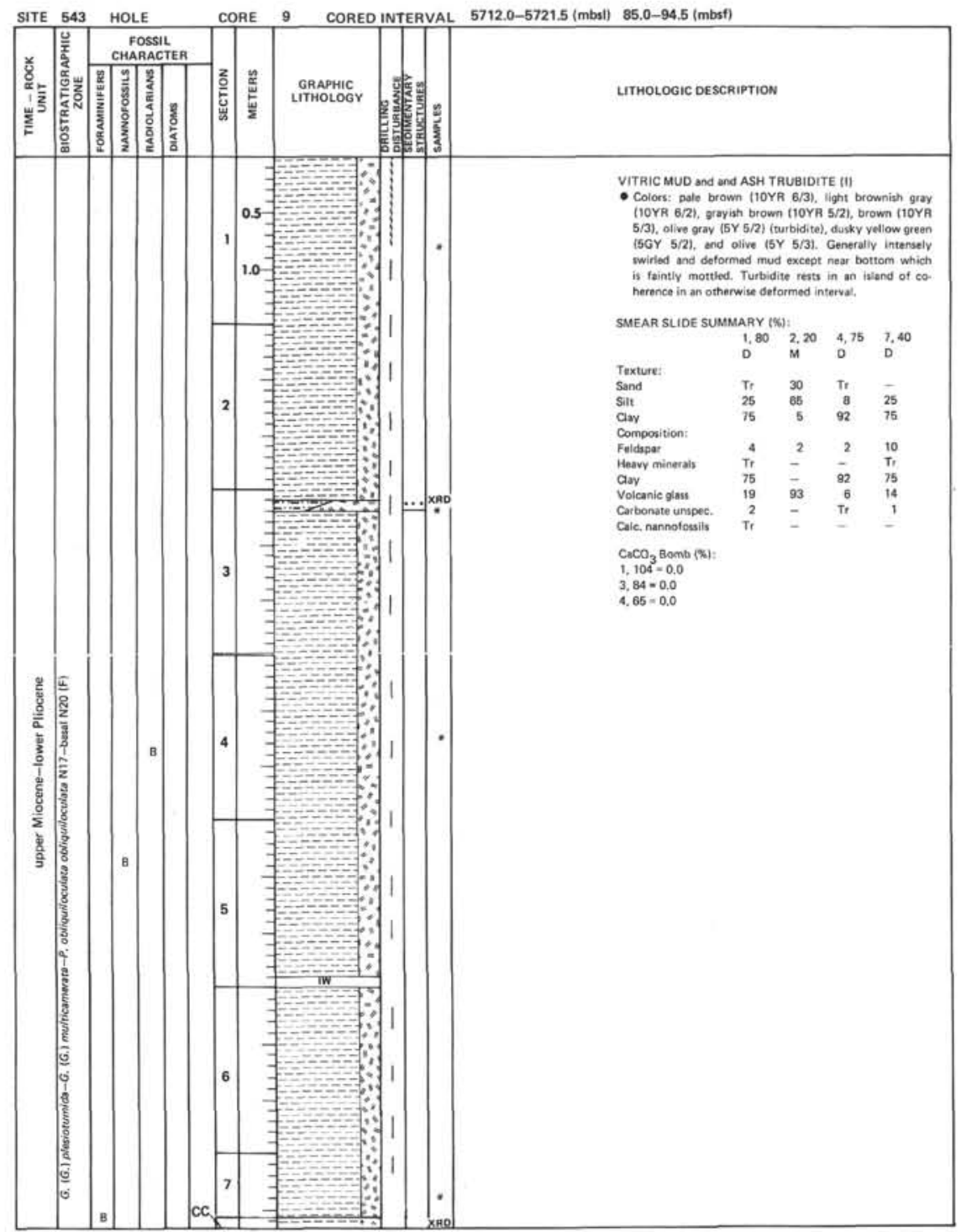

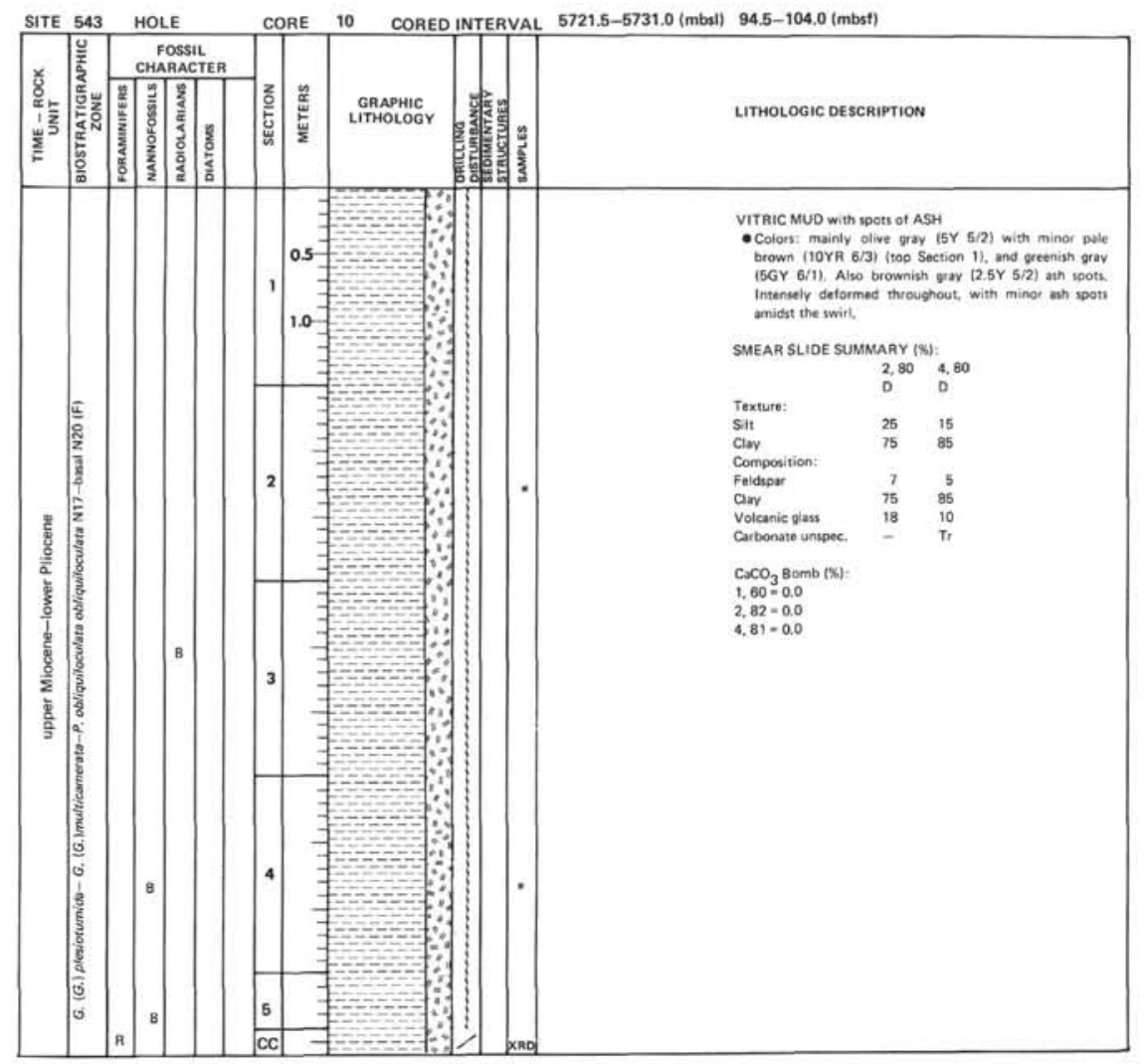

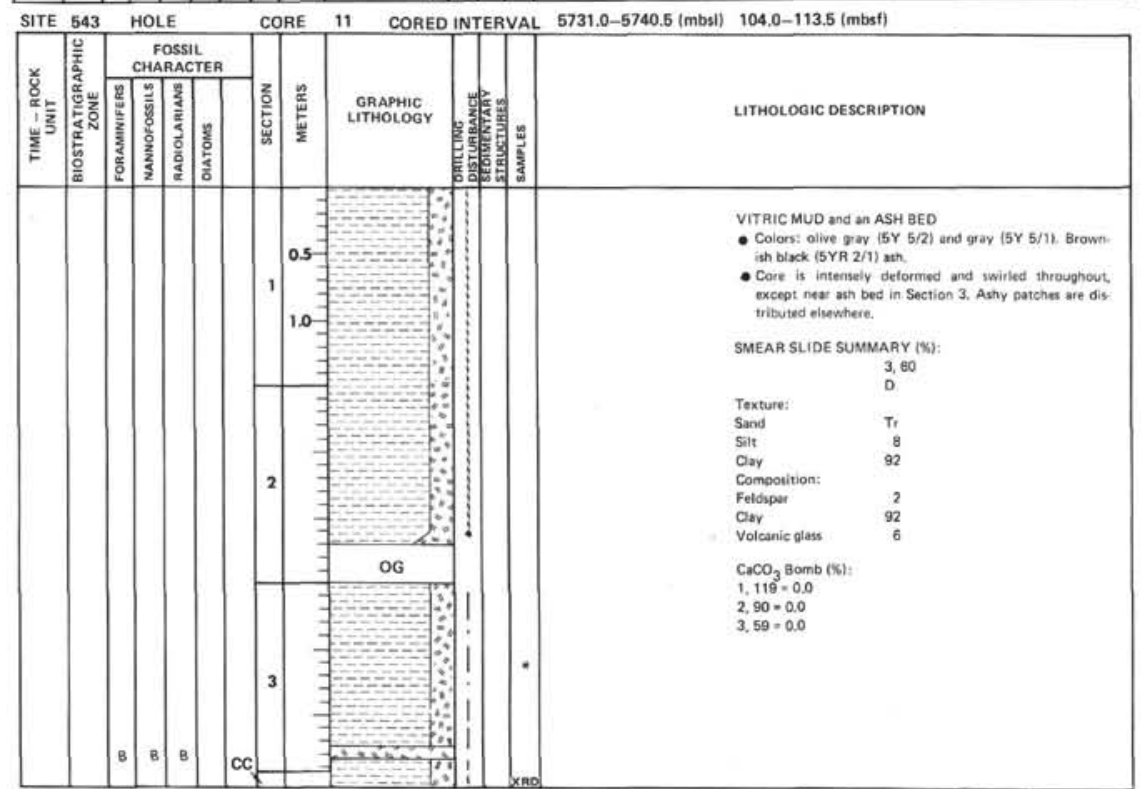



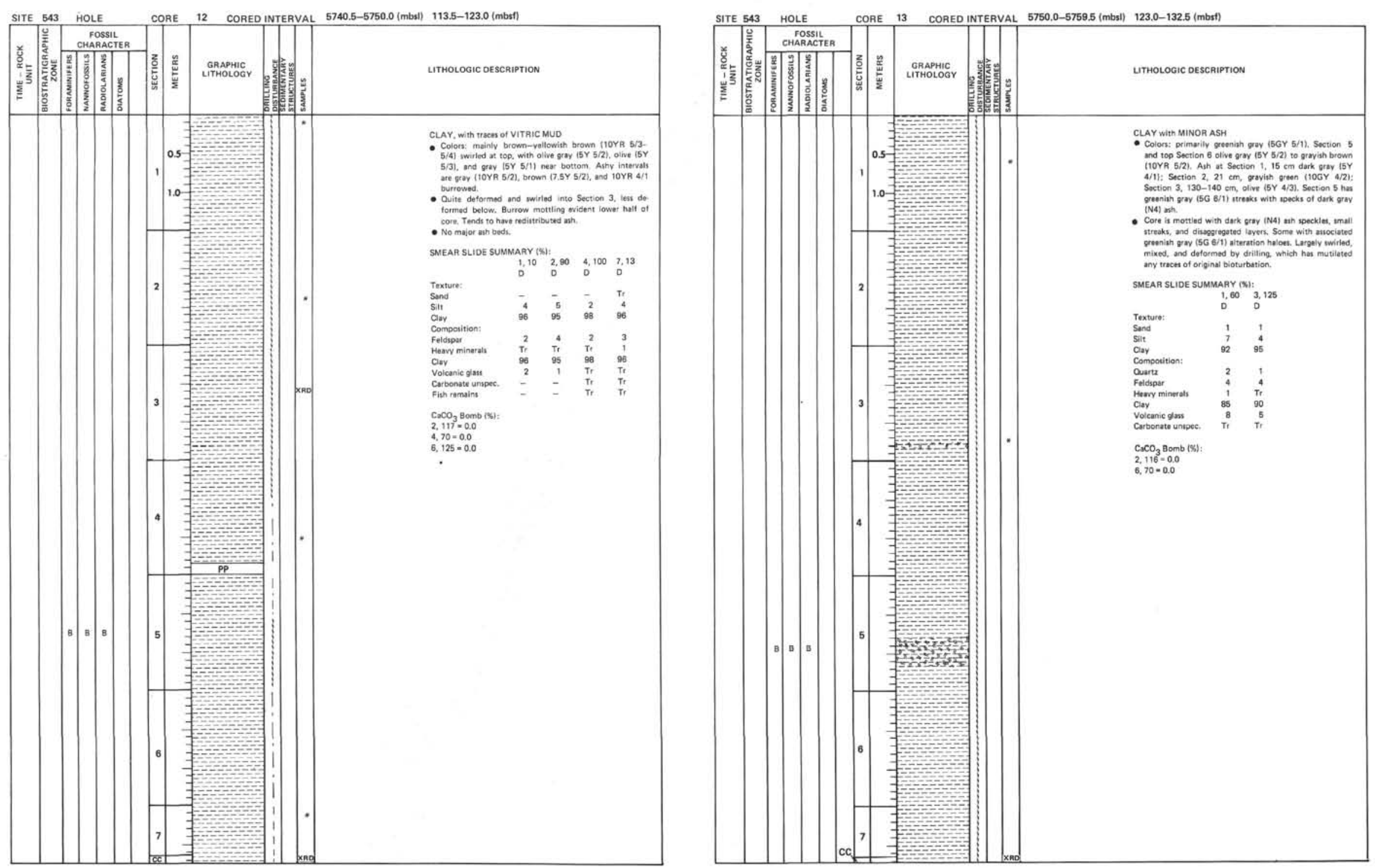

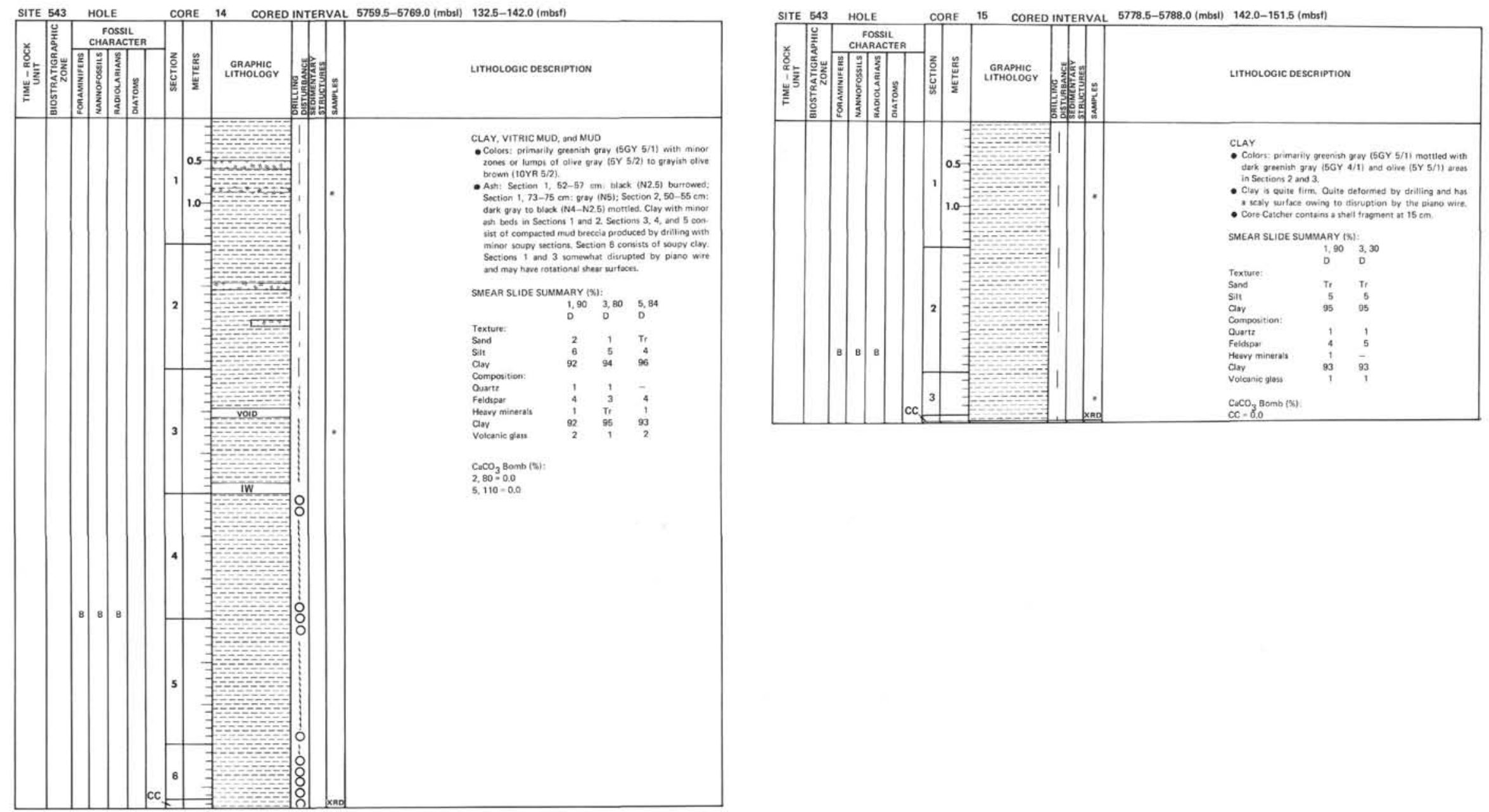

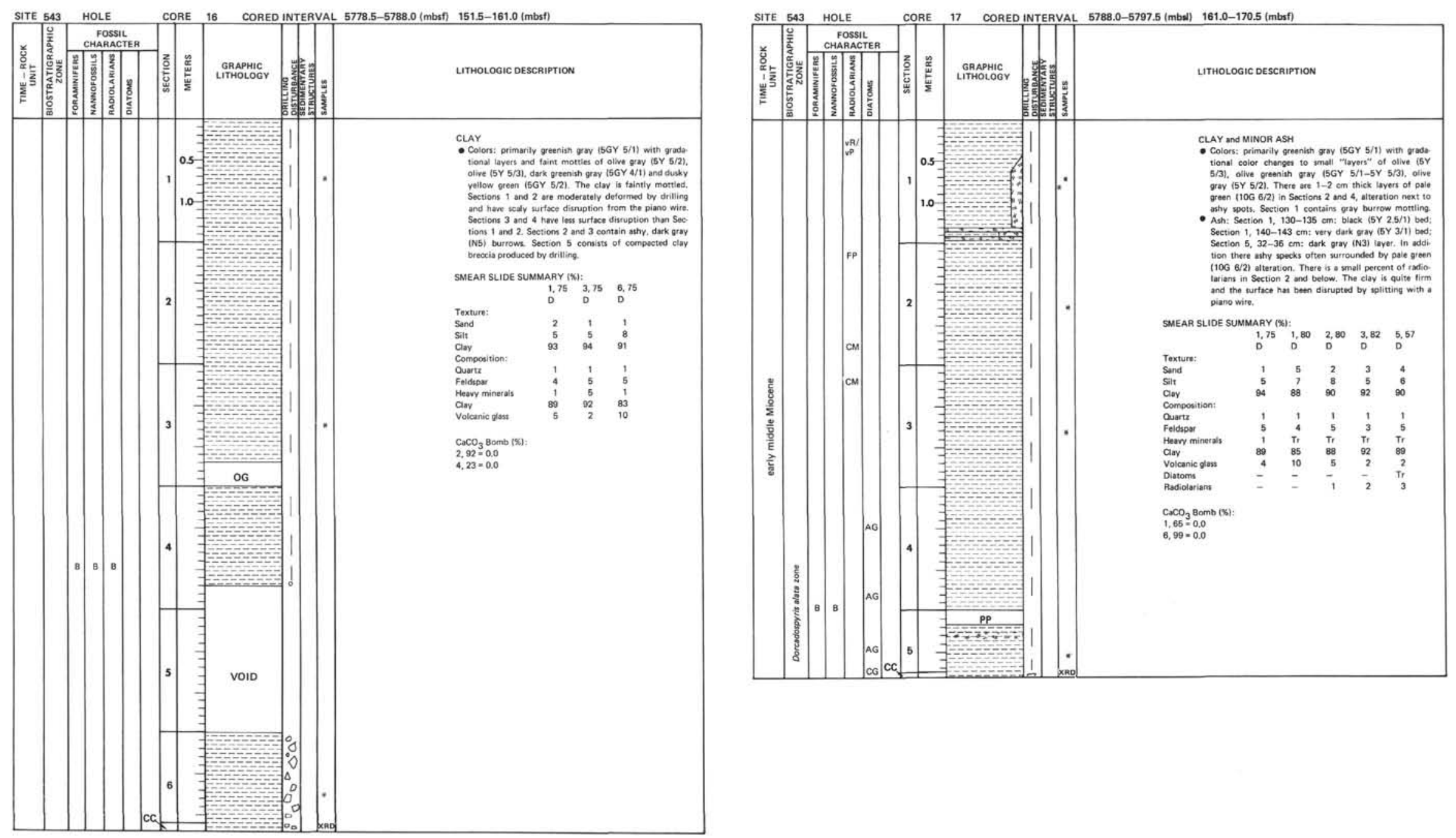

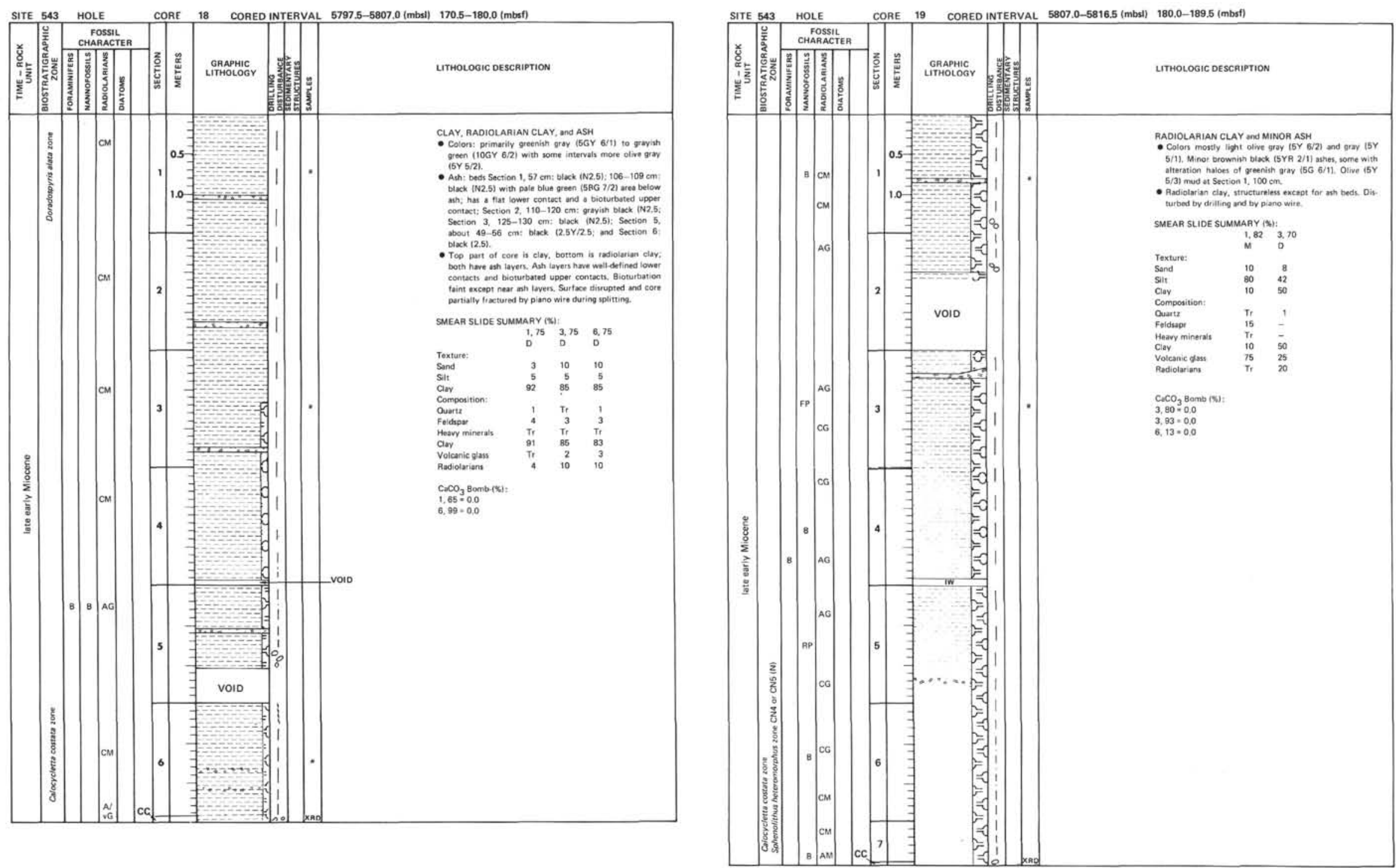

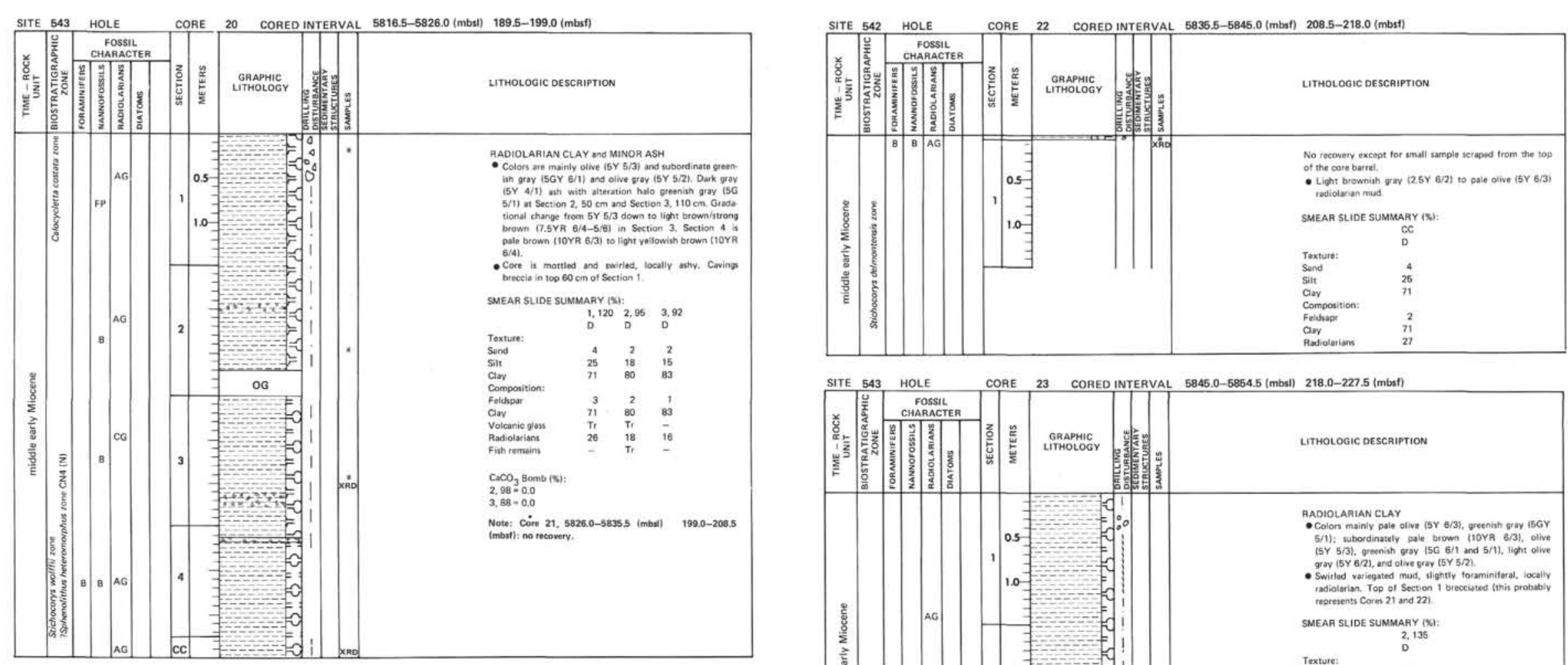

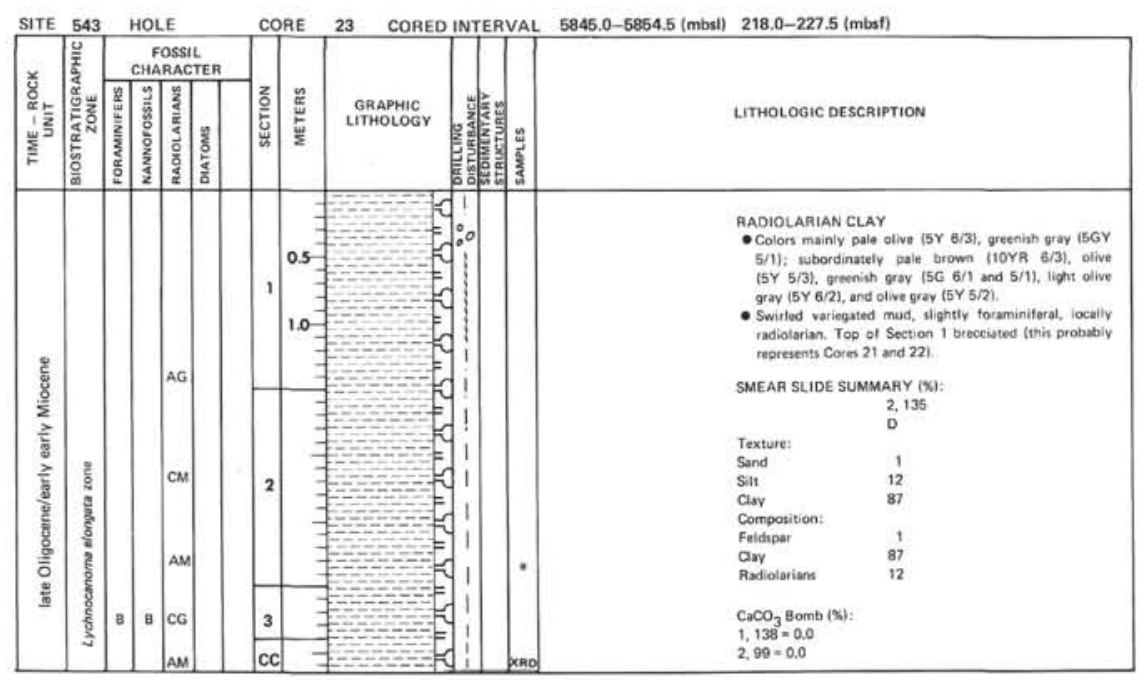



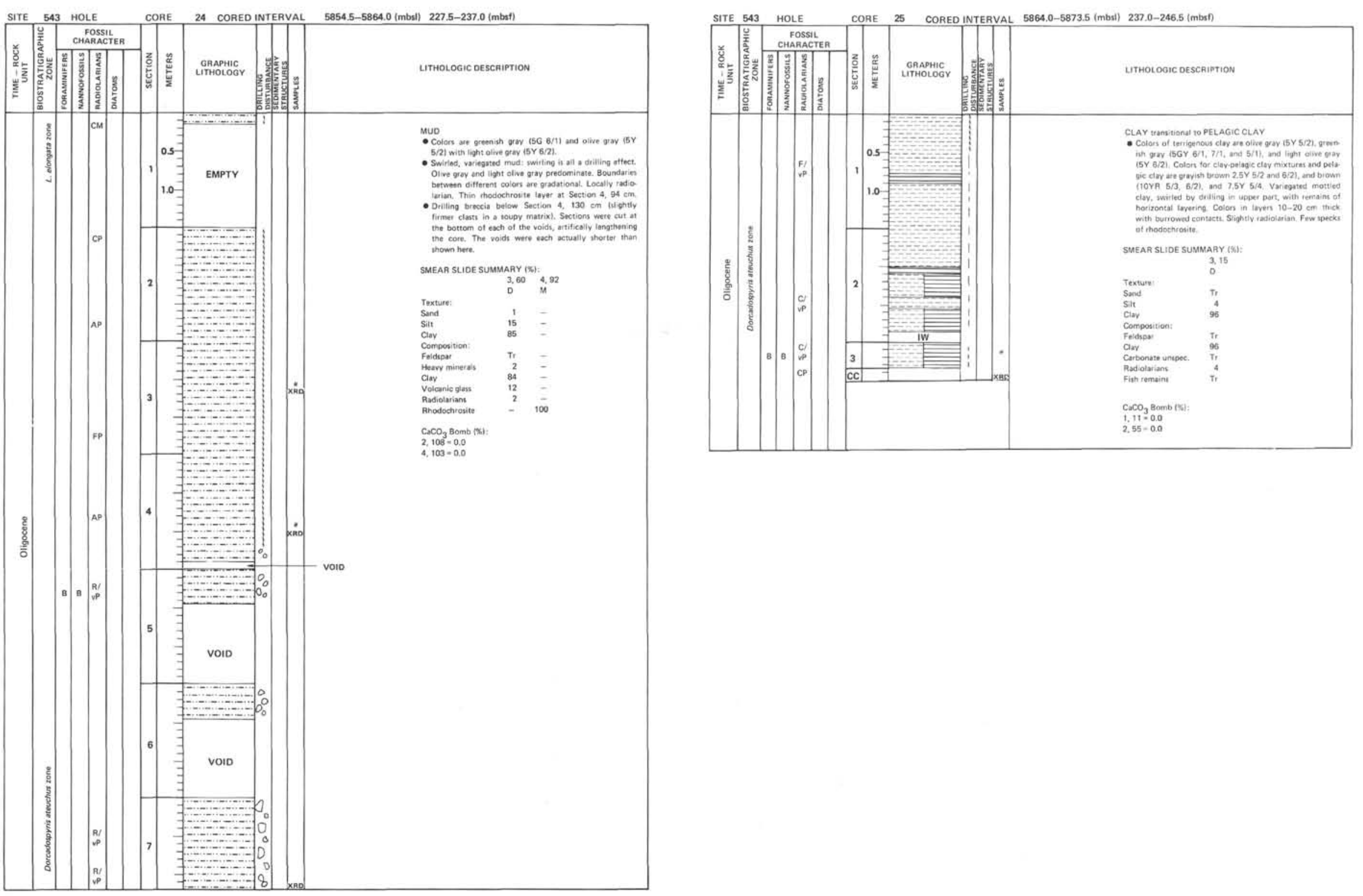

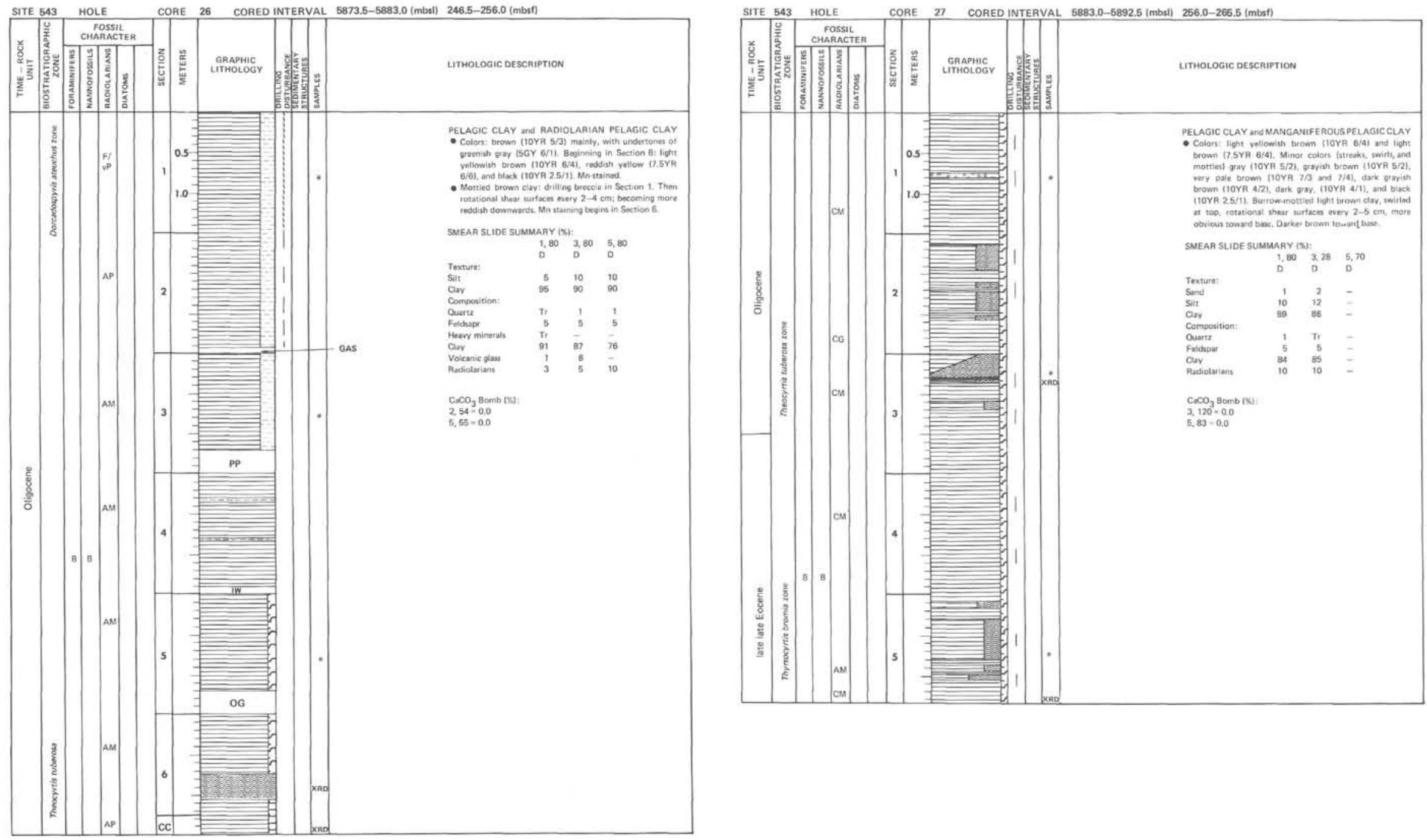

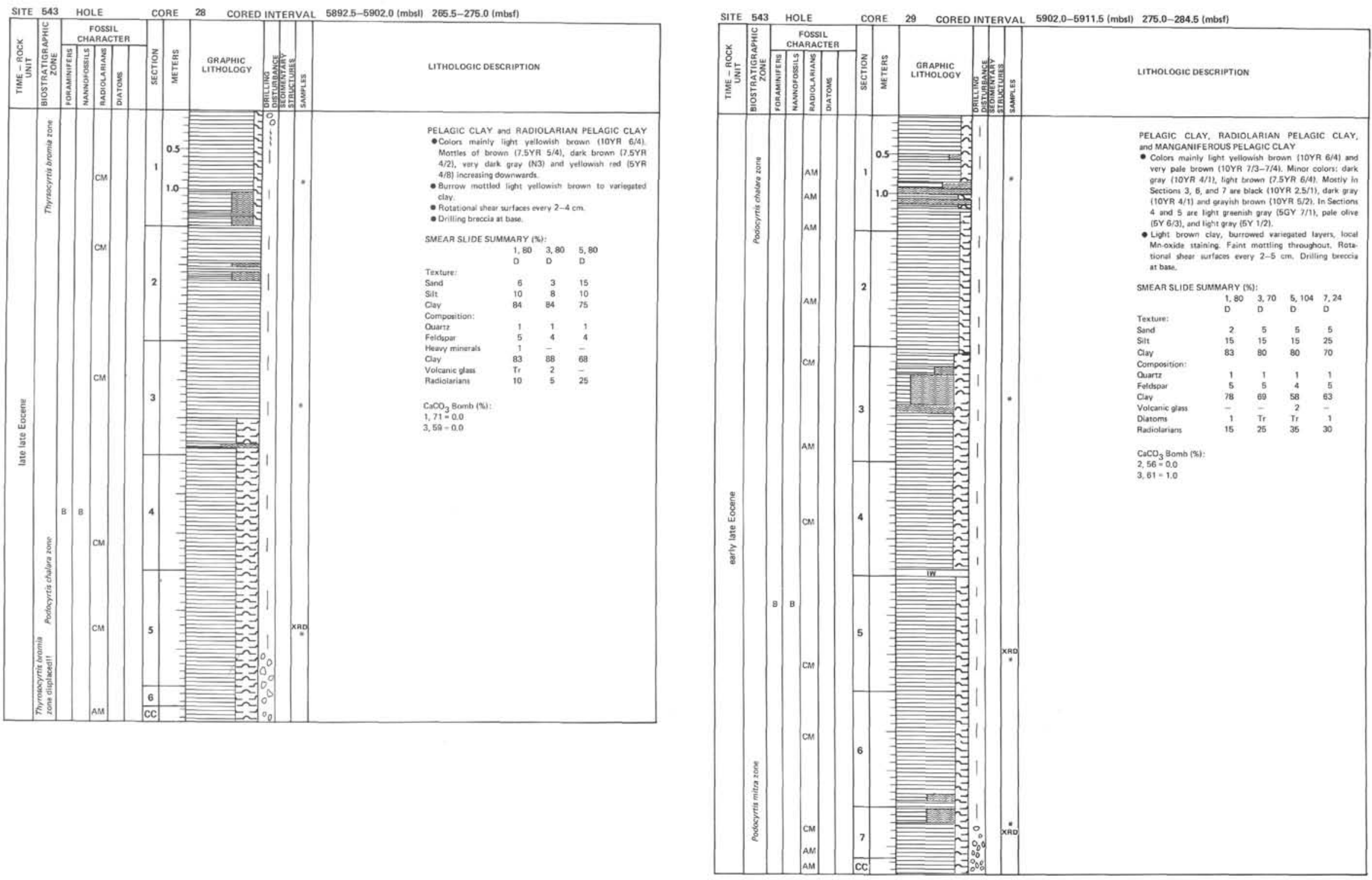


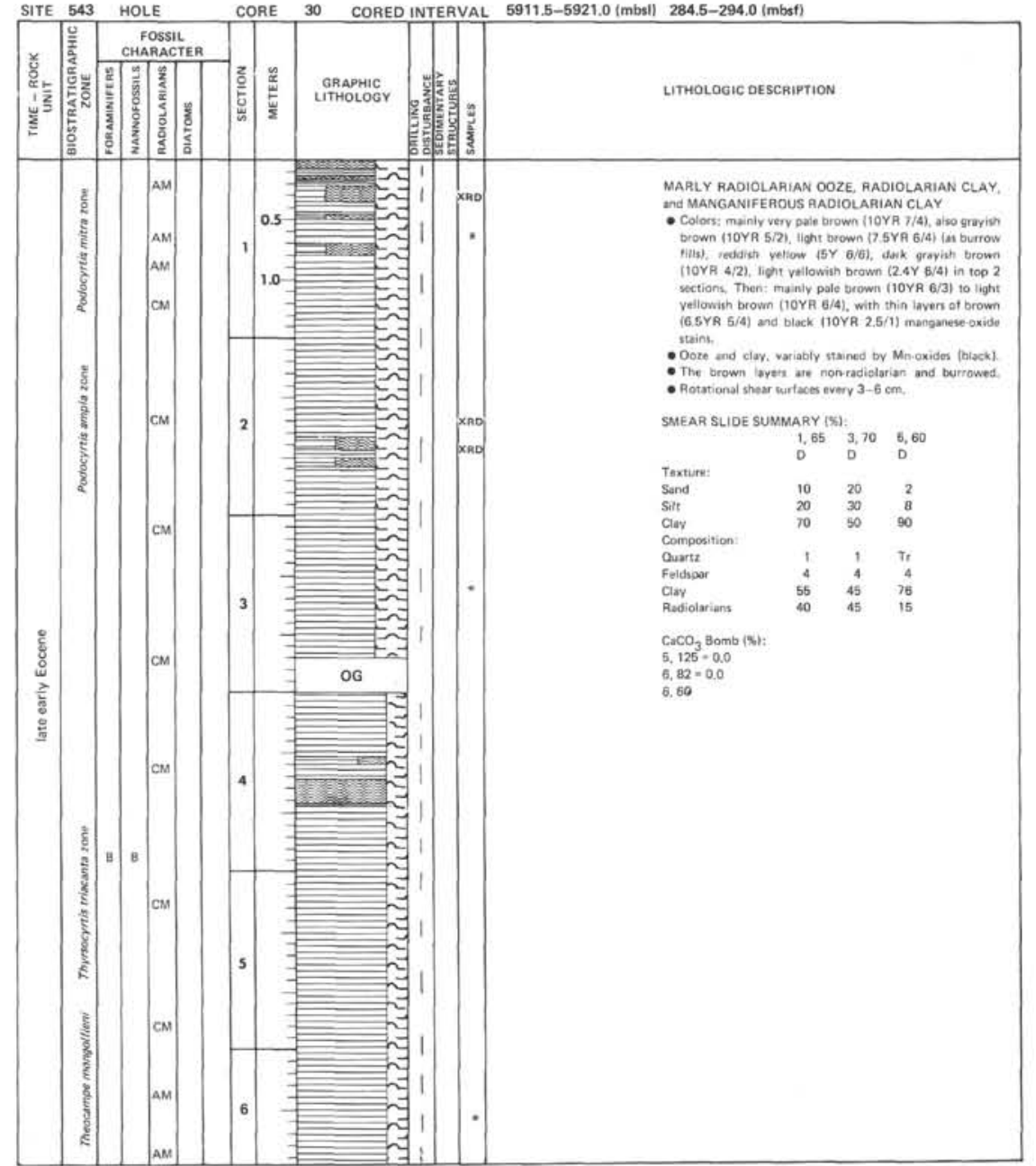

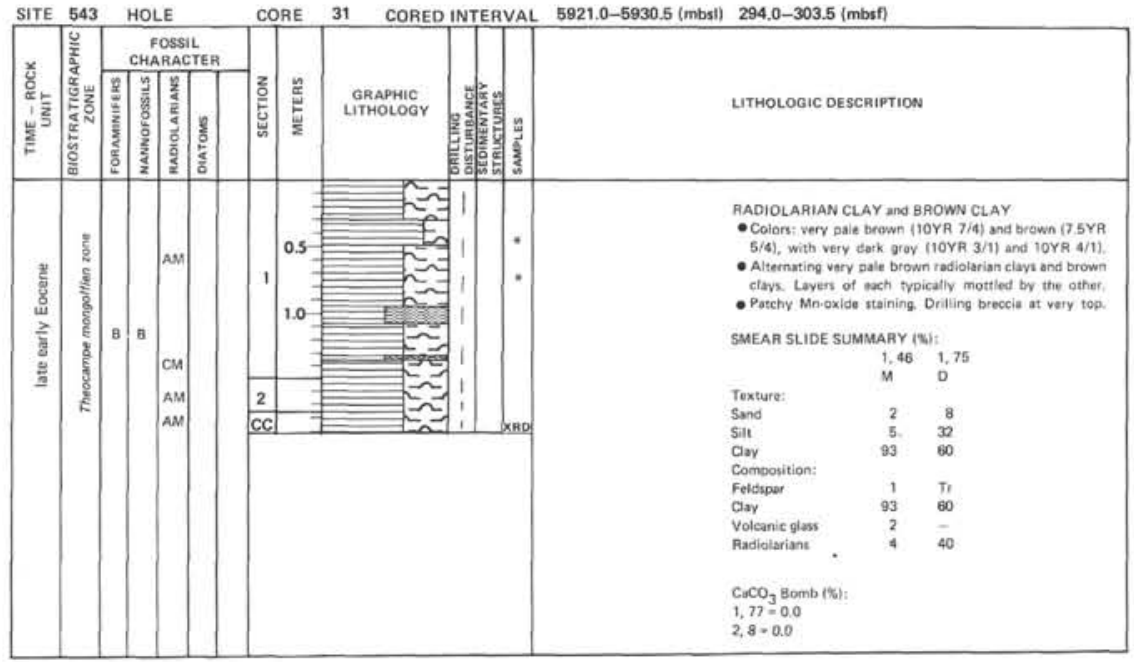

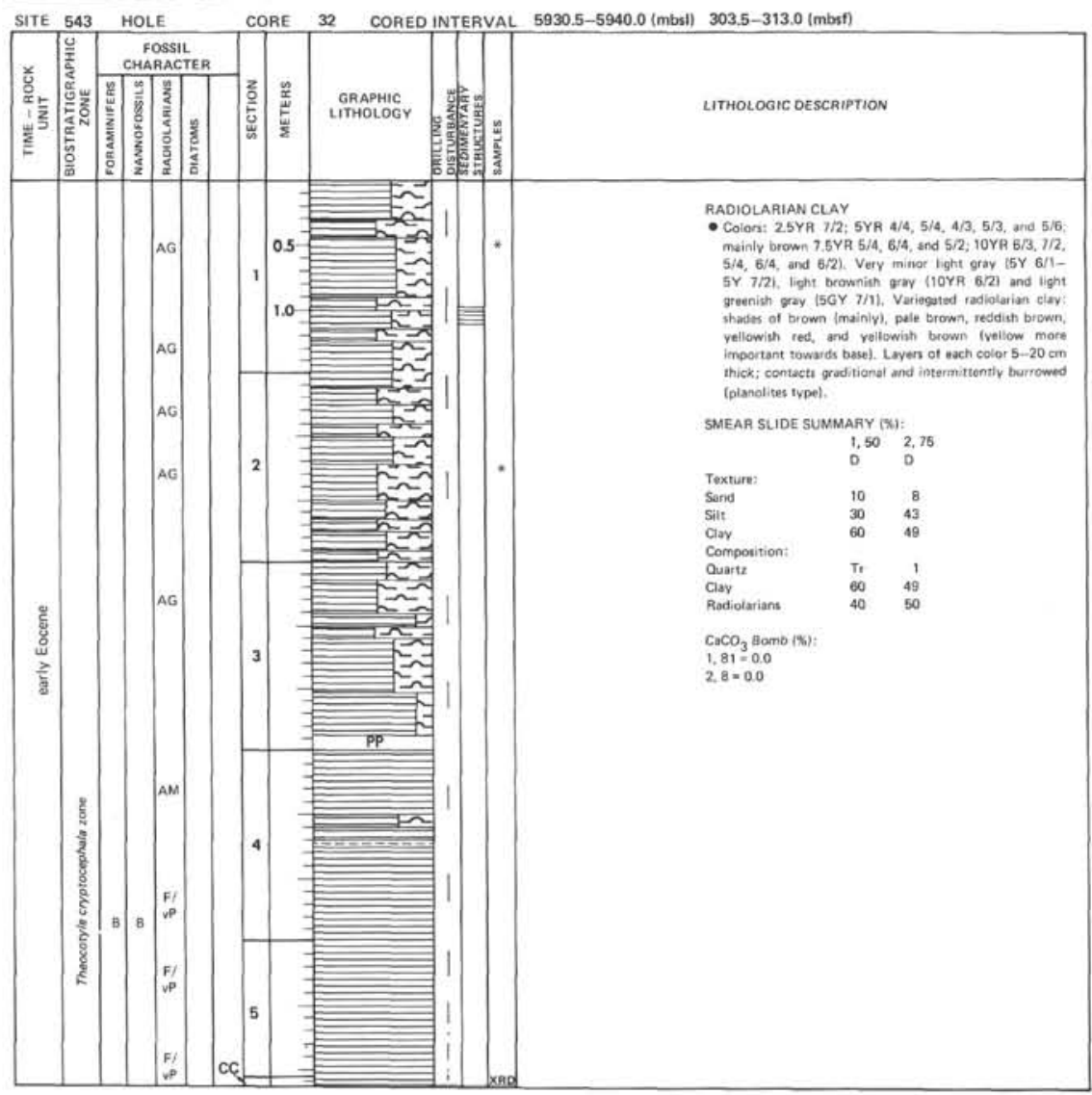



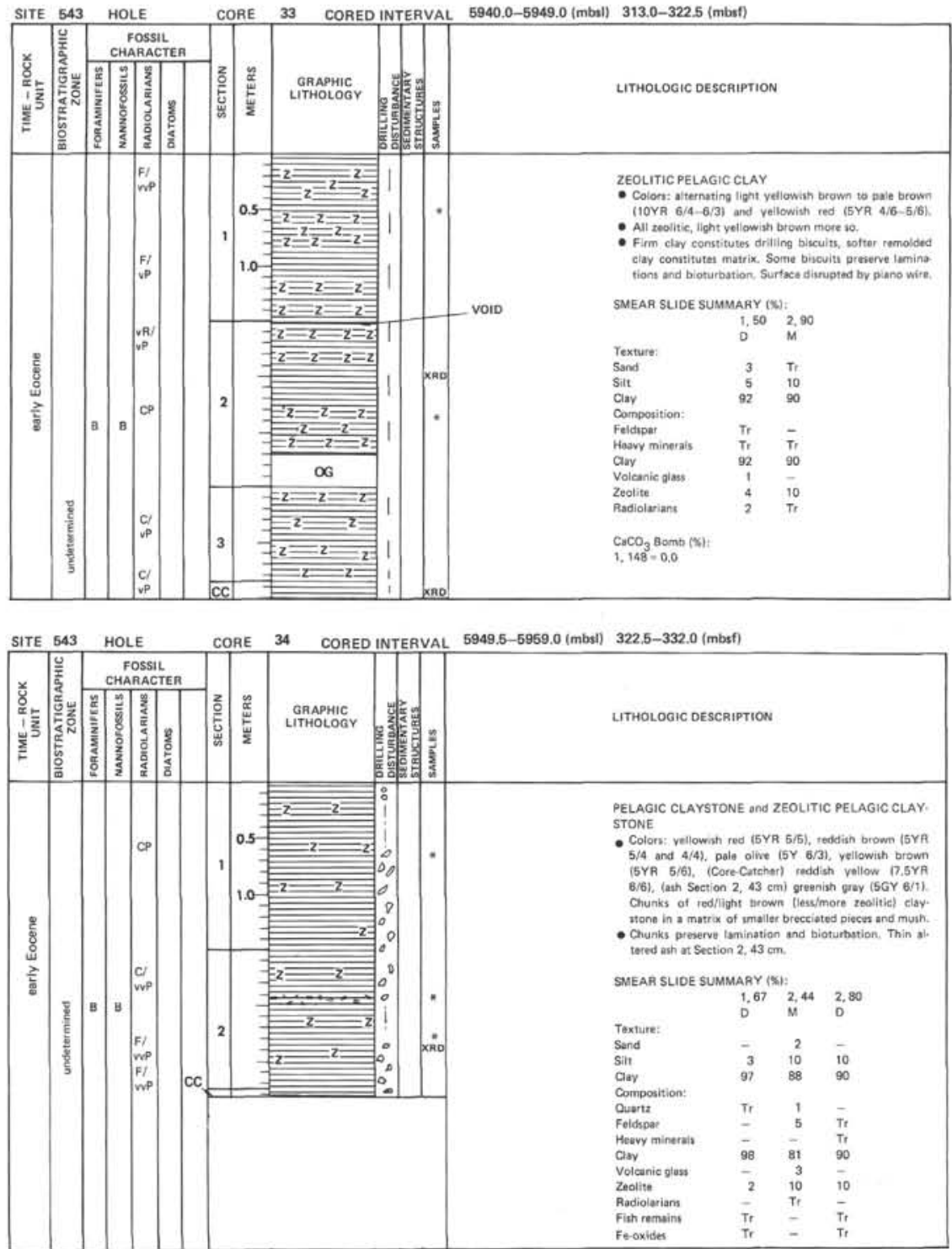

SITE 543 HOLE A CORE, 1 CORED INTERVAL $5627.0-5637.0$ (mbsl) $0.0-10.0$ (mbst)

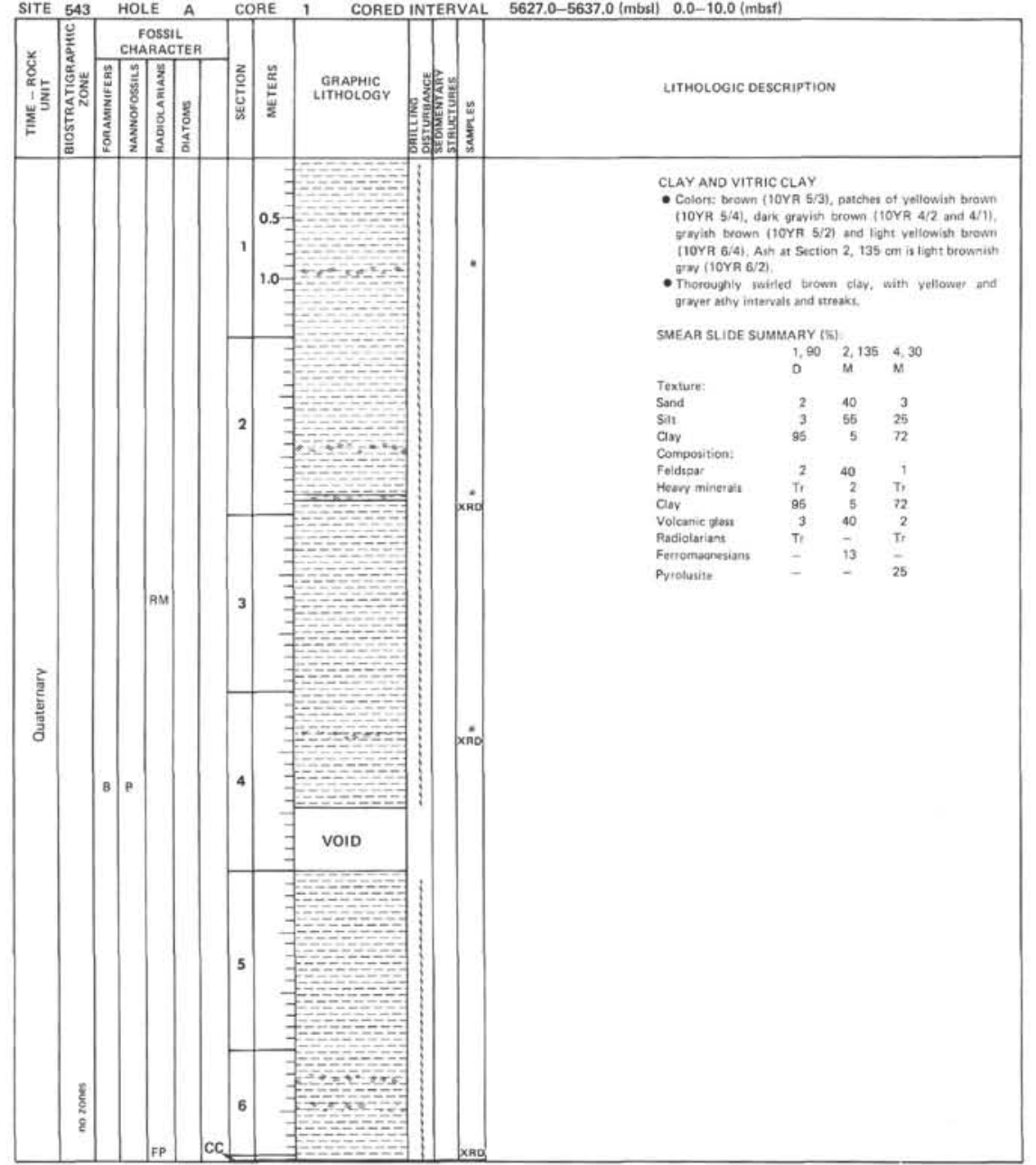




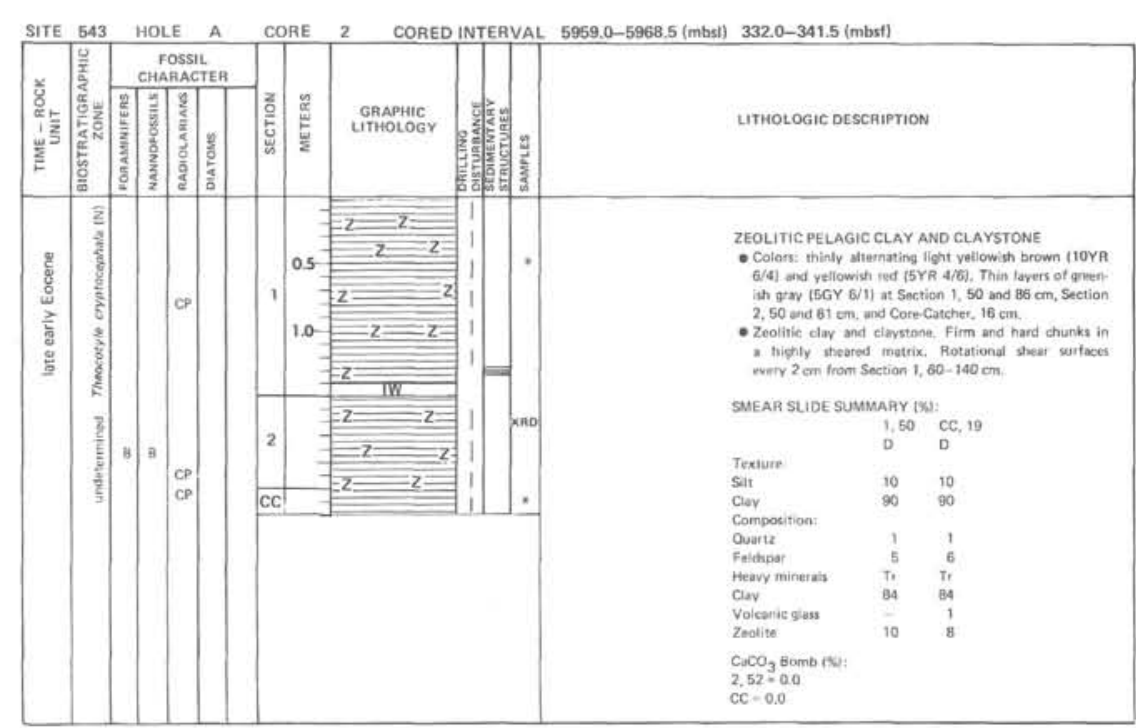

SITE 543 HOLE A CORE 3 CORED INTERVAL 5968.5-5978.0 (mbal) 341.5-351.0(mbsf)

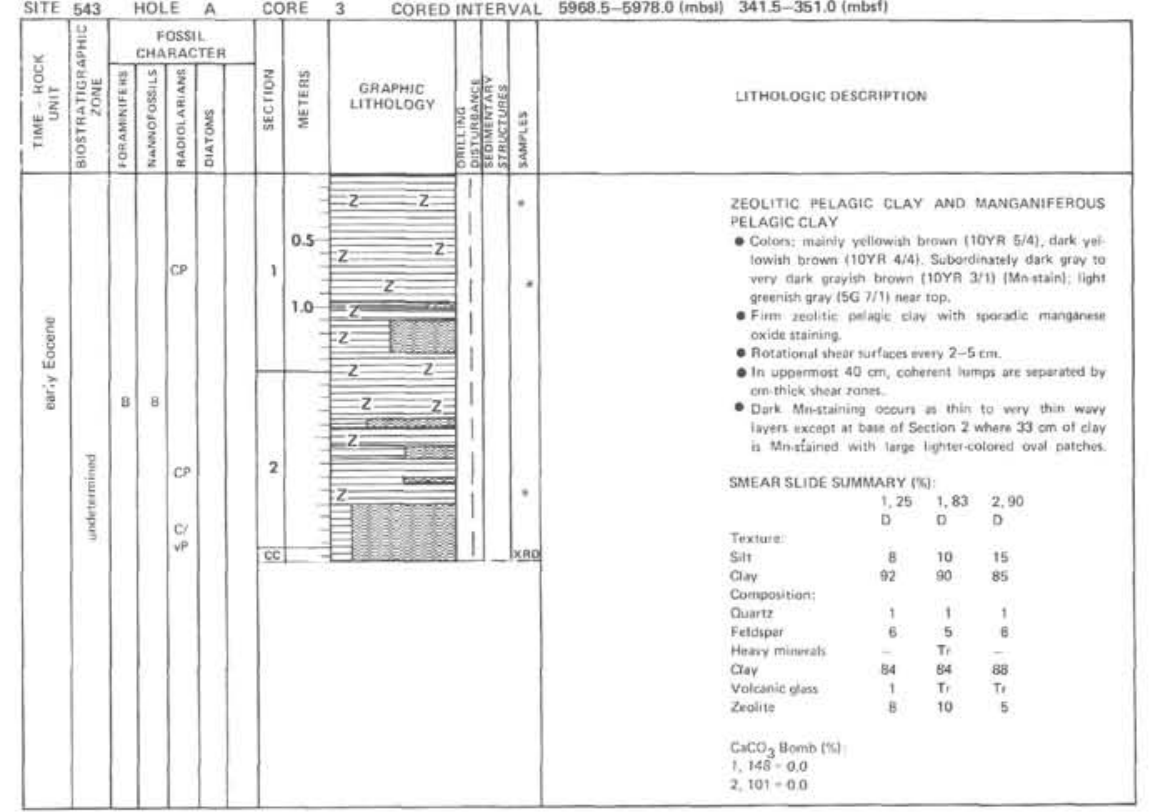

SITE 543 HOLE A CORE 4 CORED INTERVAL $5978.0-5987.5$ (mbal) $351.0-360.5$ (mbsf)

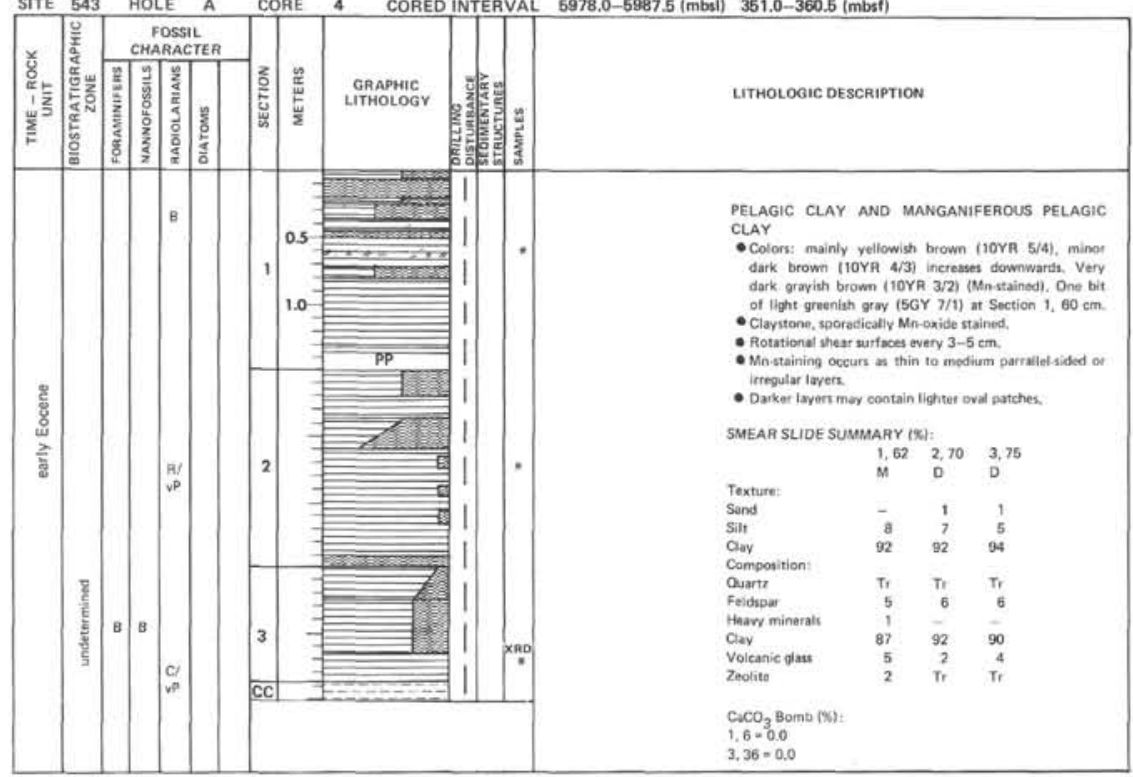

SITE 543 HOLE A CORE 5 CORED INTERVAL 5987.5-5997.0 (mbs) 360.5-3700.0 (mbSt)

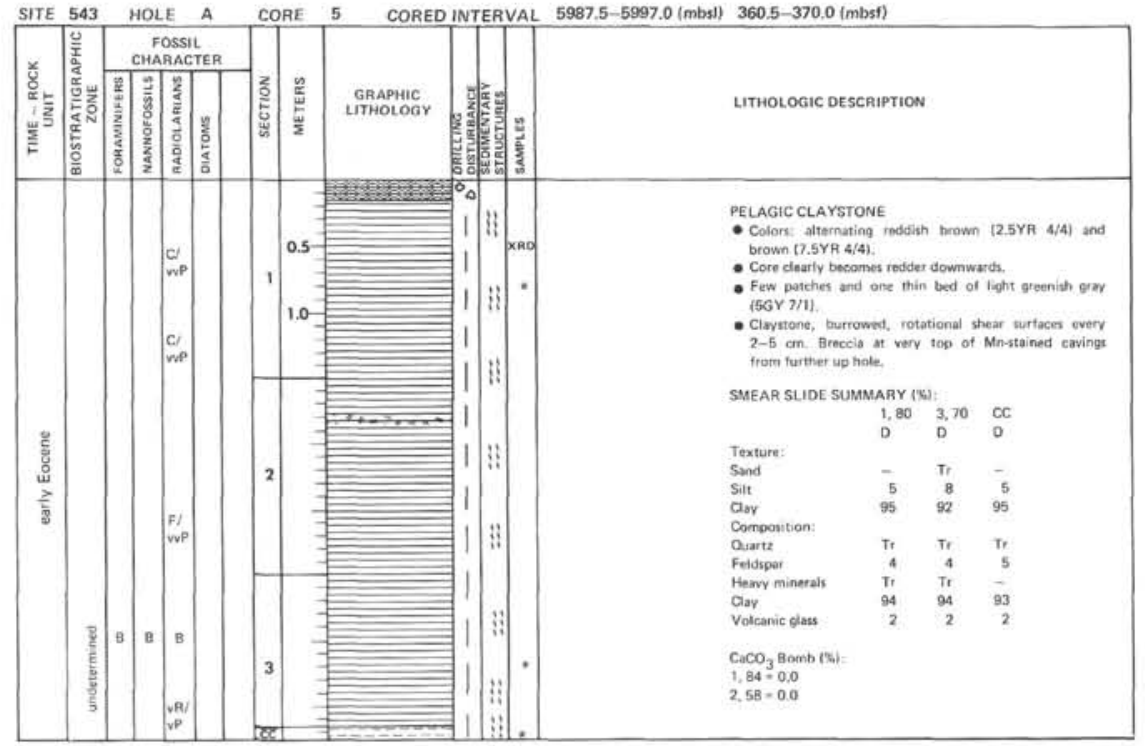




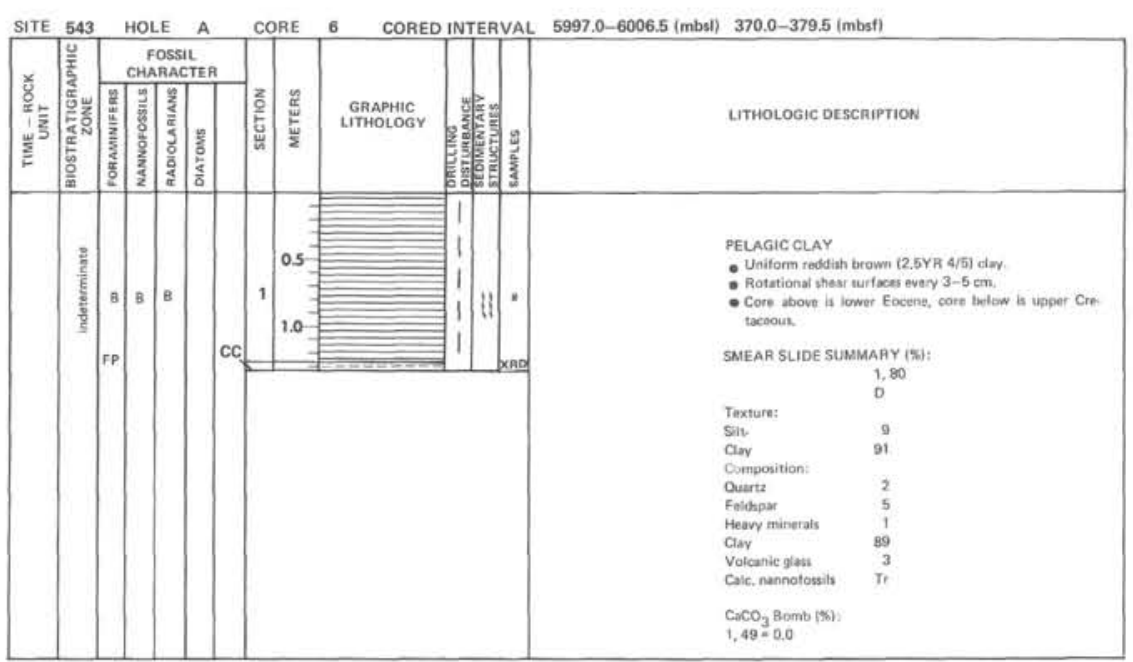

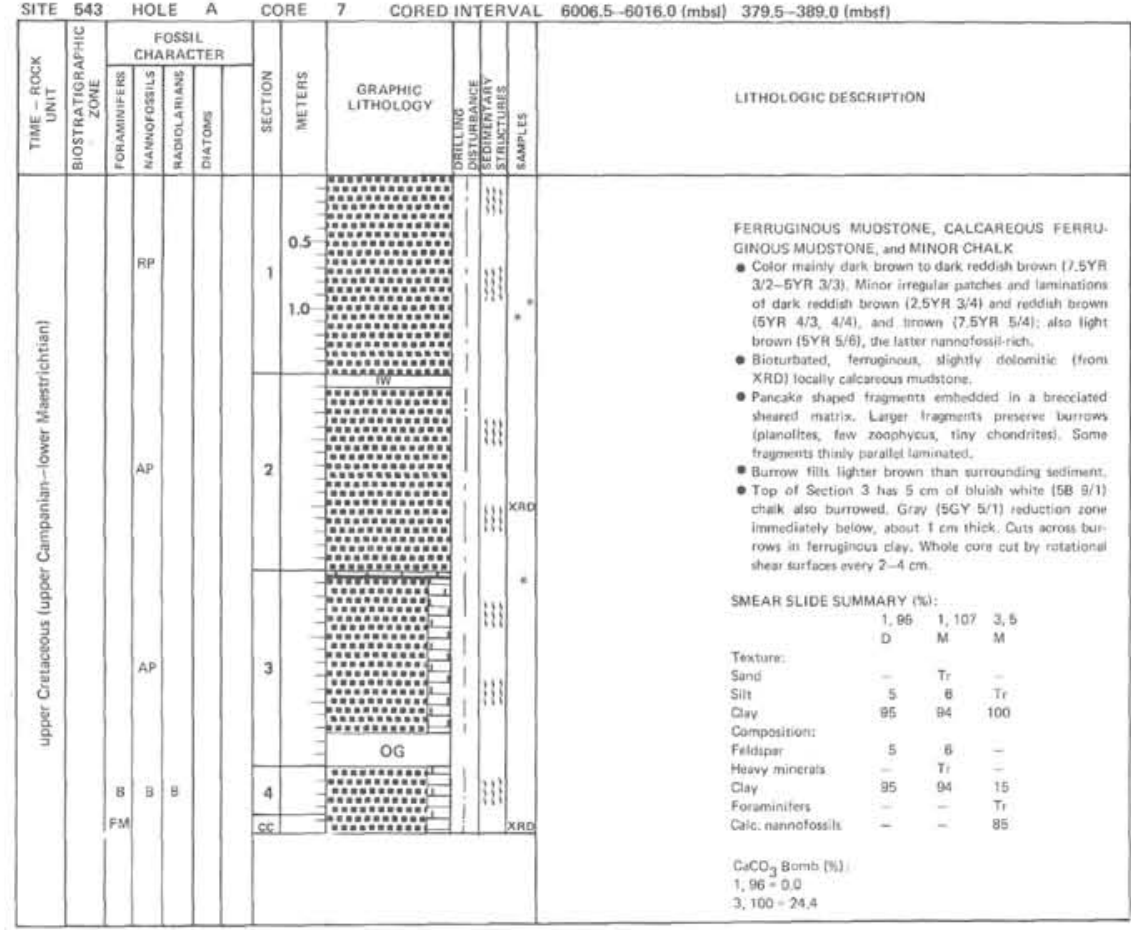

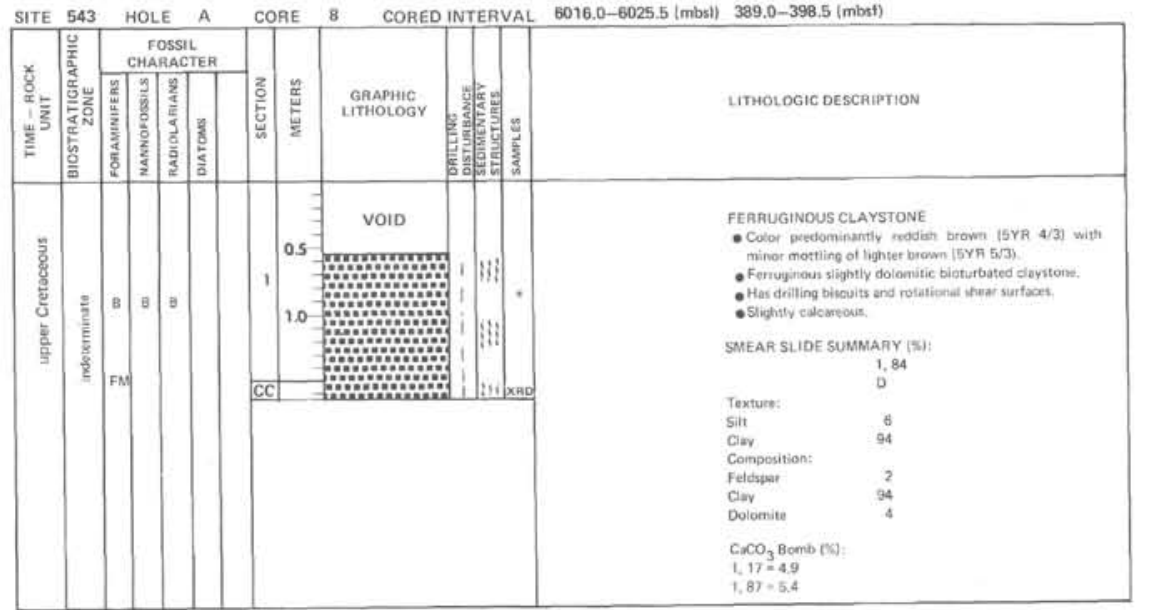




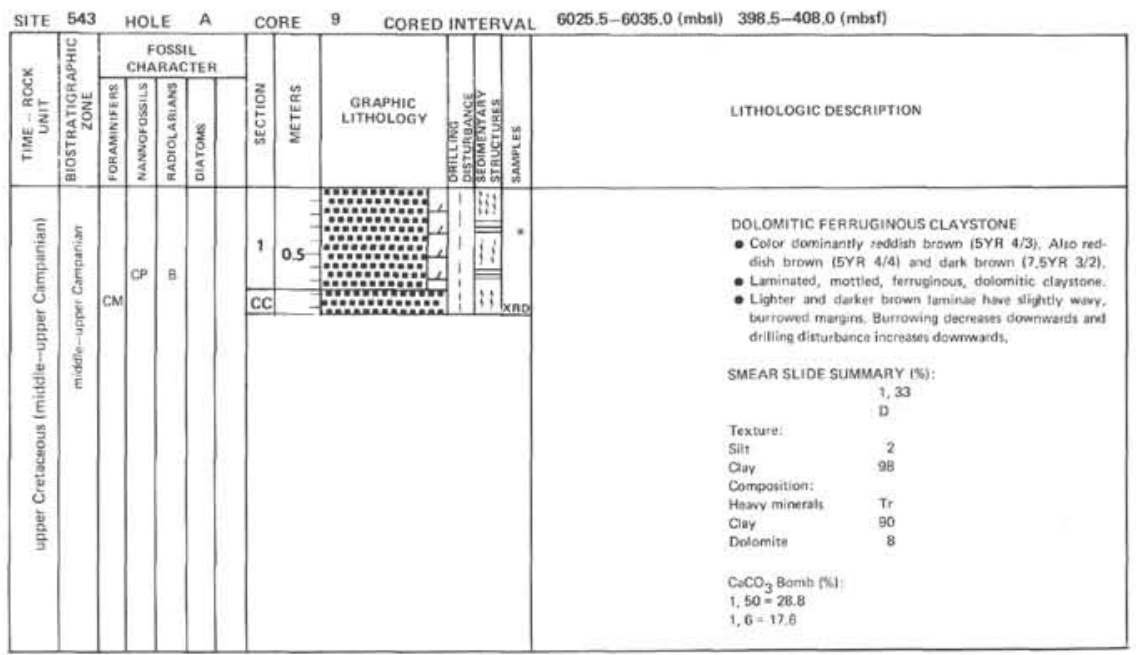

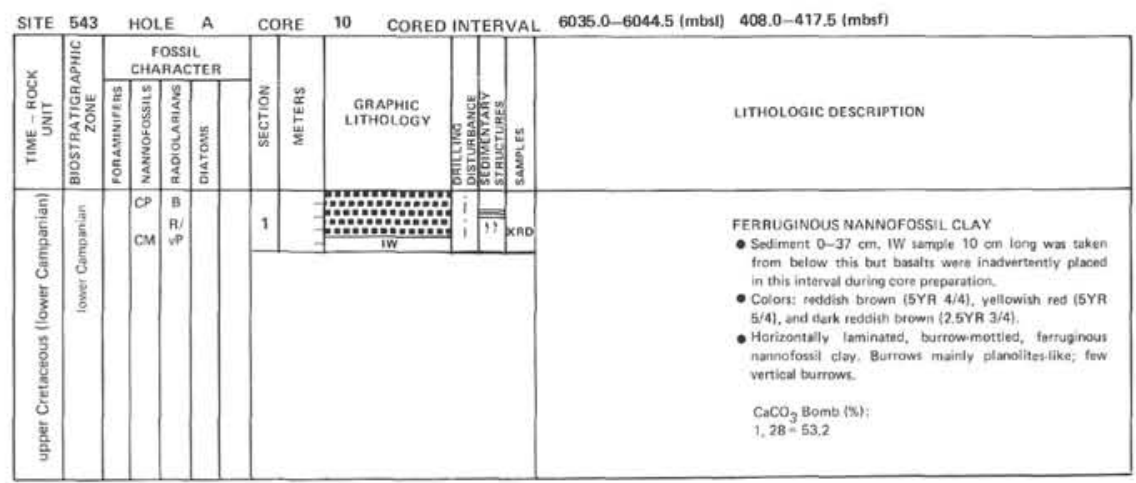




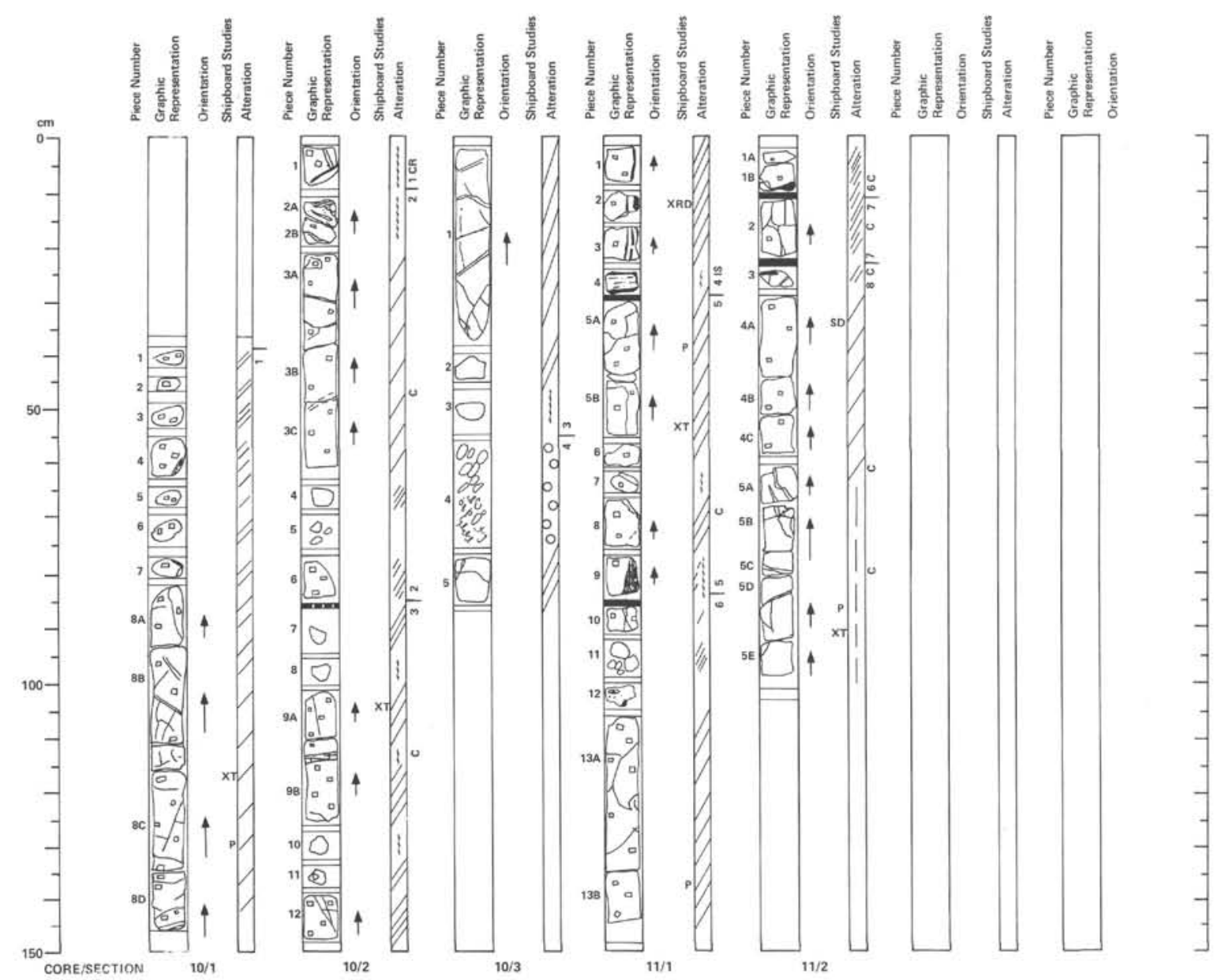

$6004.0-6054,5 \mathrm{mber}$

784.543A.10

PLAGIOCLASEOLIVINE MODEAATELY PHYYIC BASAL

4110-4175 mots

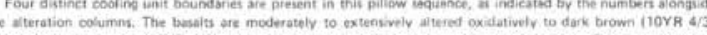

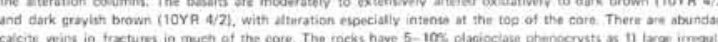

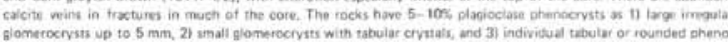

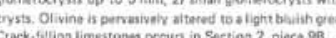

Thin Section Dexcitition

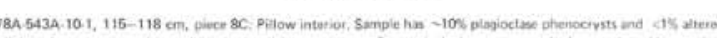

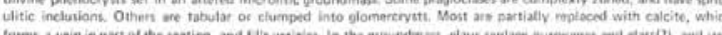

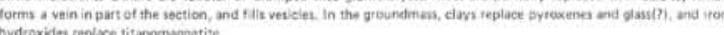

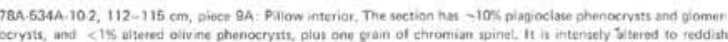

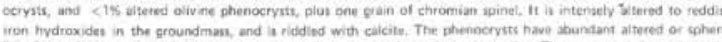

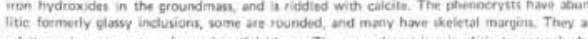

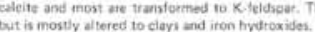

$0054.5-6057.0 \mathrm{mbu}$

78A.543A.11 175-4200 mas

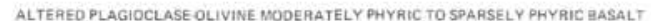

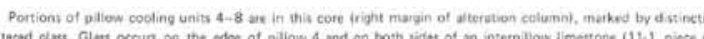

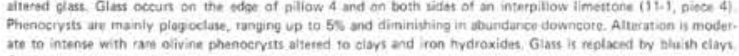

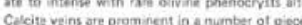

Thin Section Deteciptions

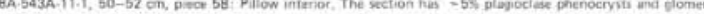

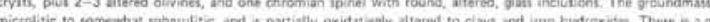

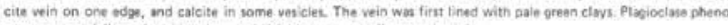

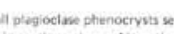

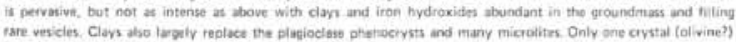
is repilaced by colcitito. 


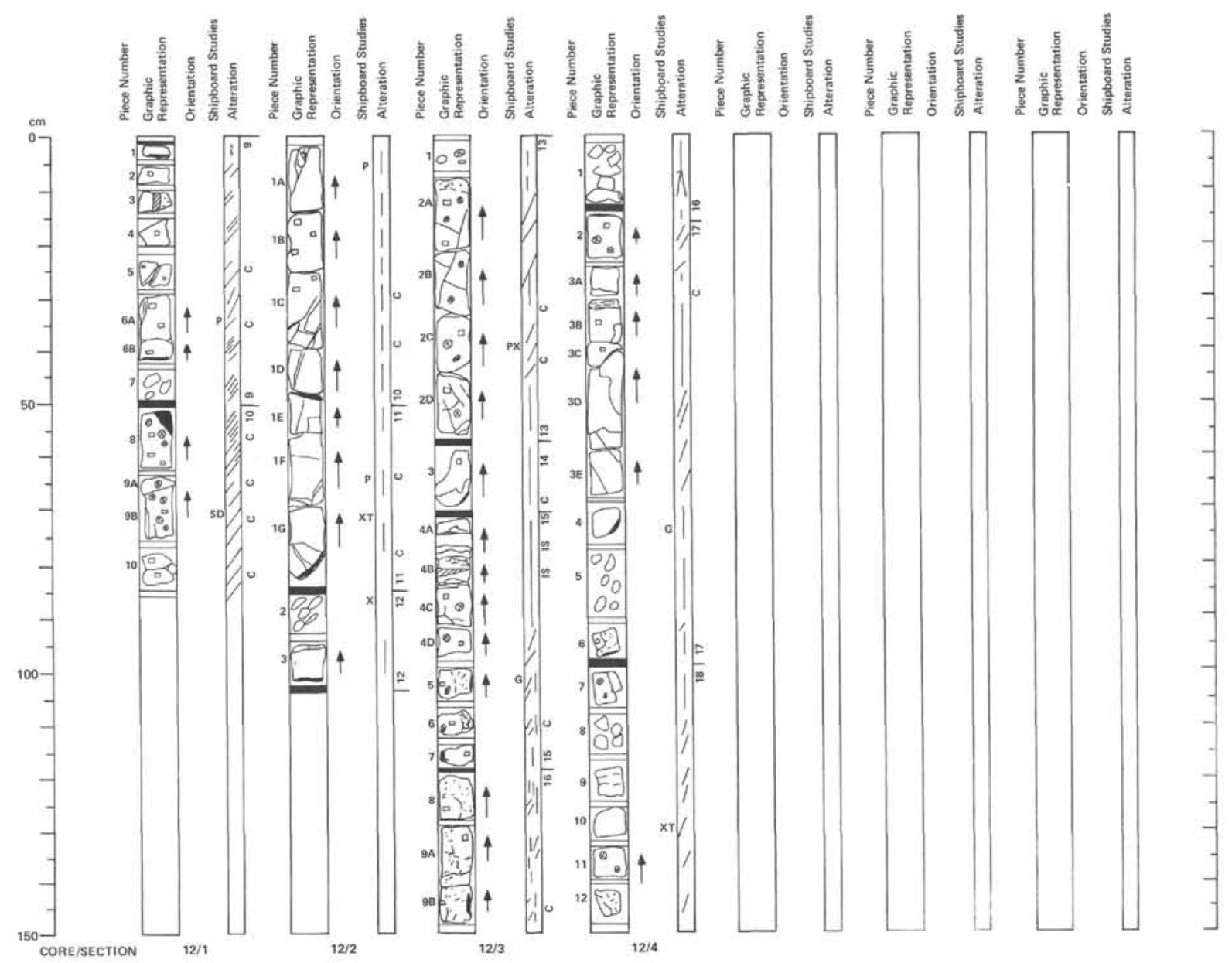

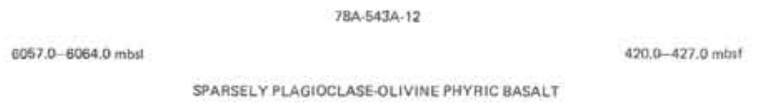

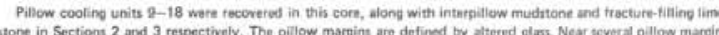

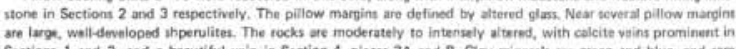

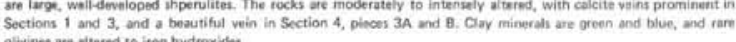
Thin Section Dececioition

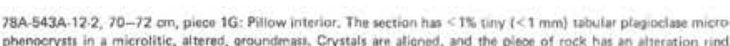

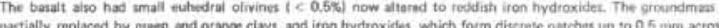

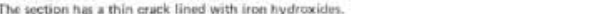

wearred by

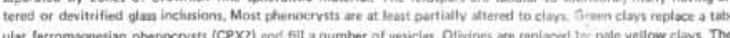

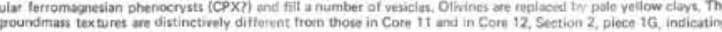

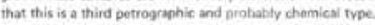




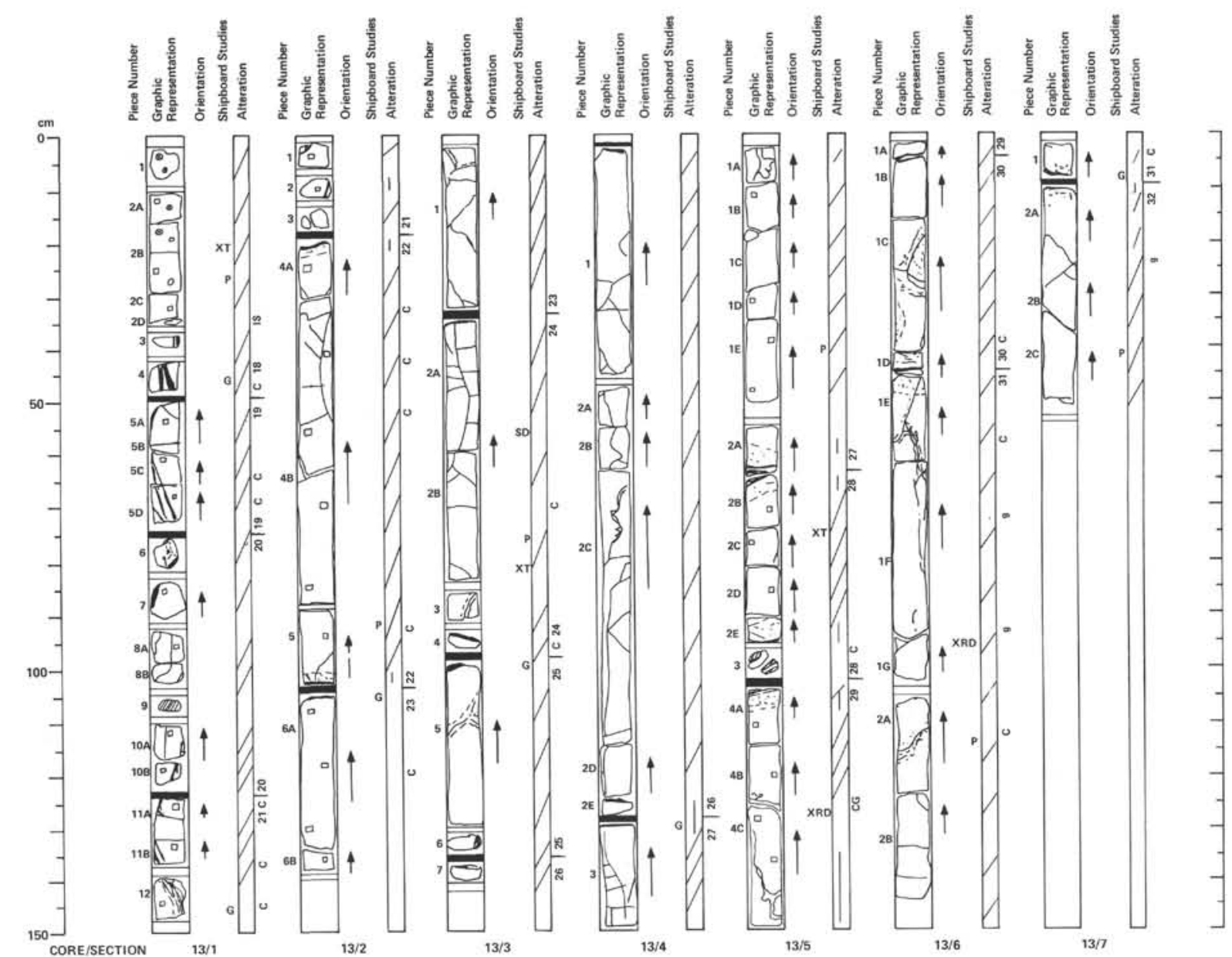

6064.0-6073.0 mbal

sensasent

$427.0-436.0 \mathrm{mtht}$ SPARSELYMODERATELY PLAGIOCLASE OLIVINE PHYMIC

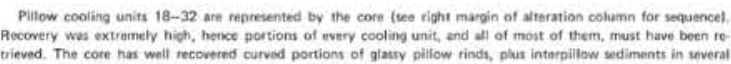

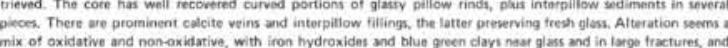

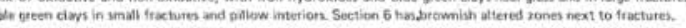

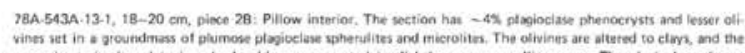

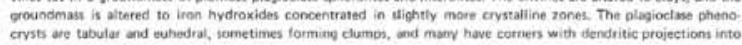
the groundmast Most are teploceced by clivyt.

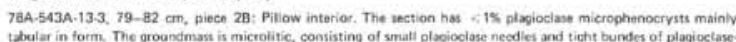

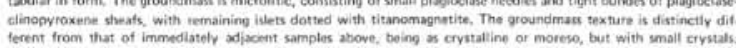

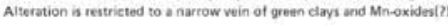

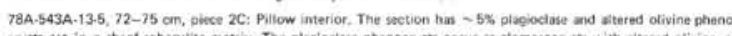

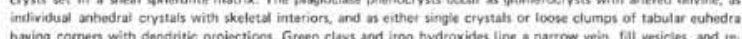

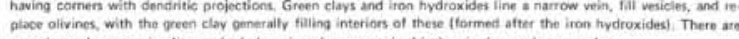

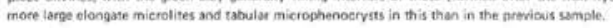




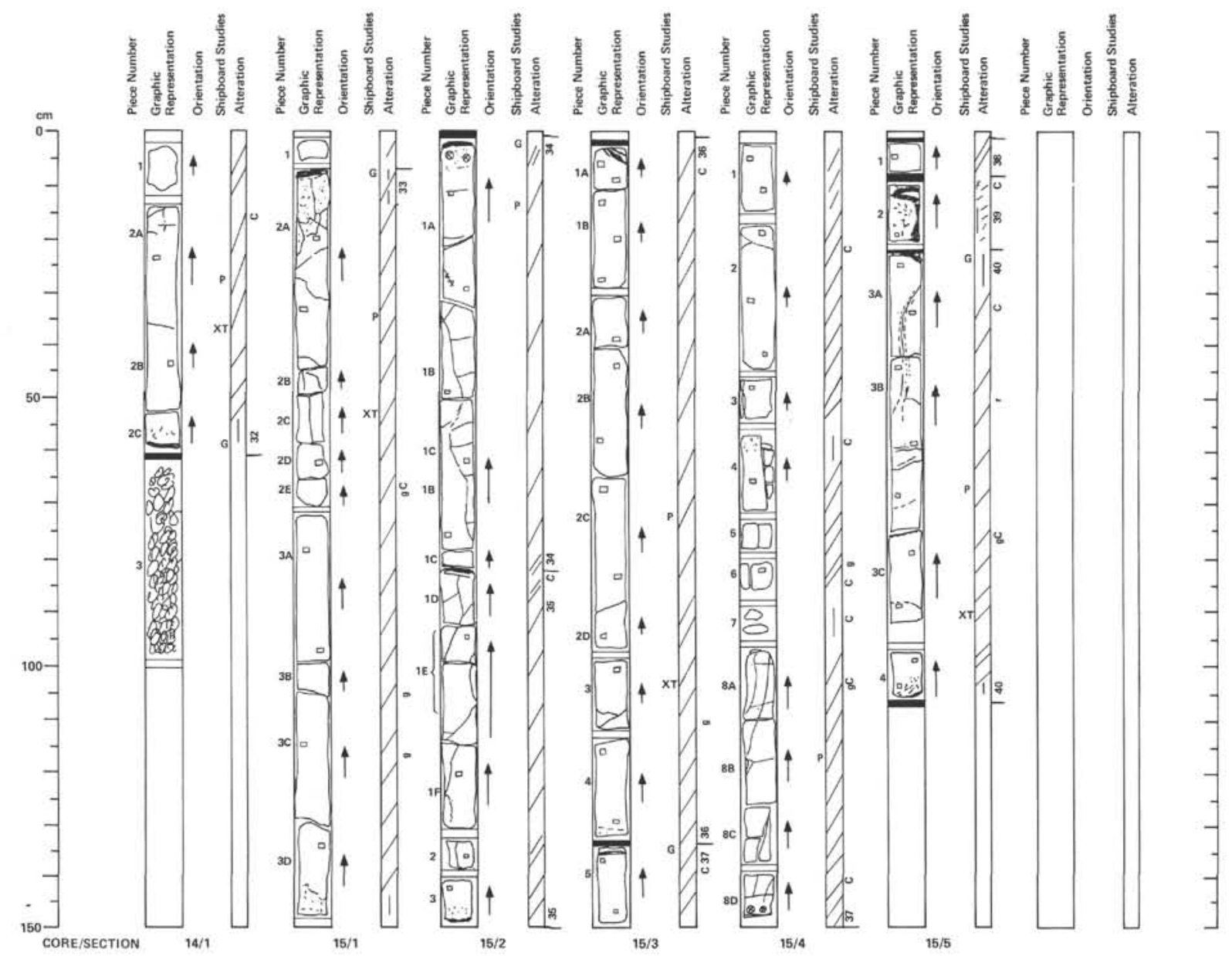

973.0-6075.0 most

78A.543A.14

ARSELY PLAGIOCLASE-OLIVINE PHYRIC BASALT

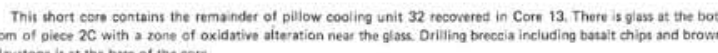
mone of ox

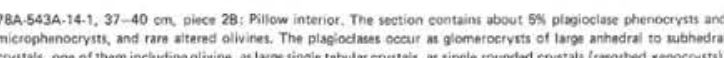

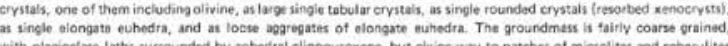

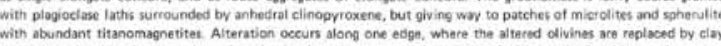

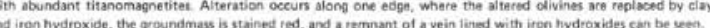

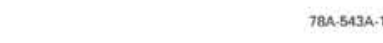

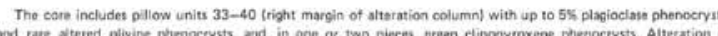

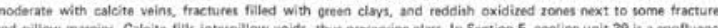
ats Thin Section Descipiptions

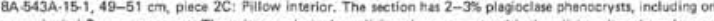

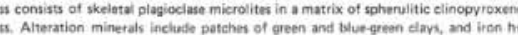

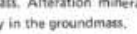

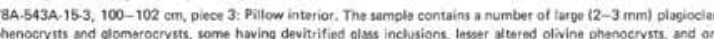

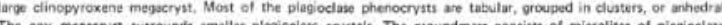

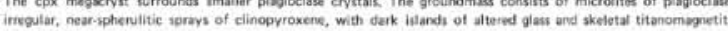

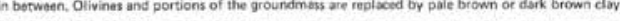

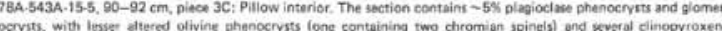

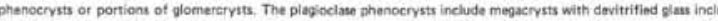

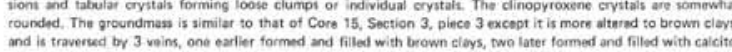




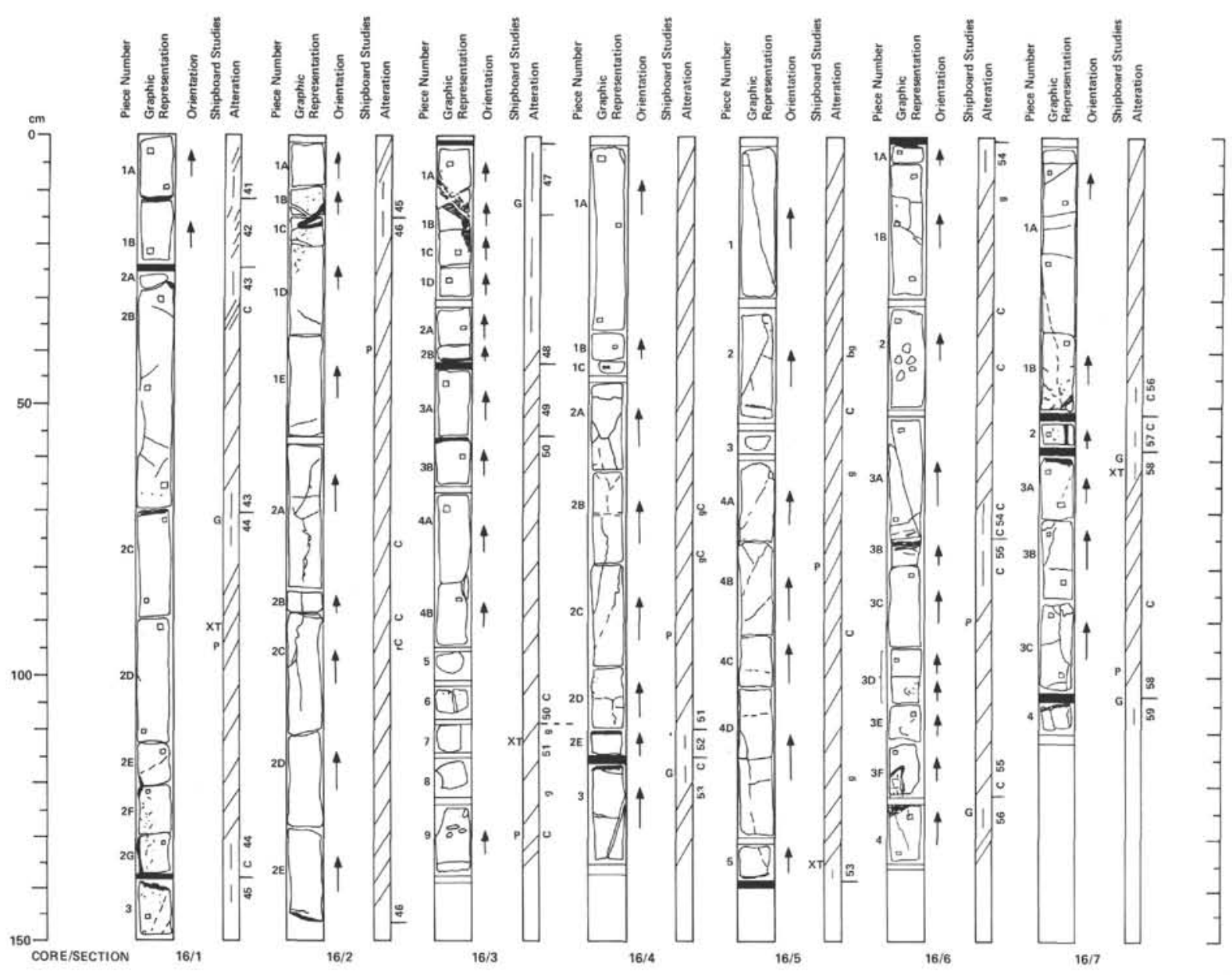

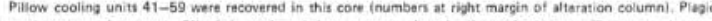

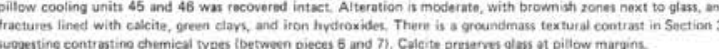

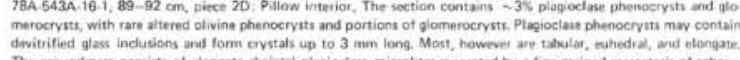

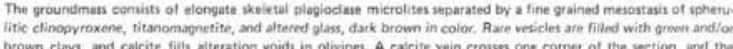

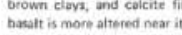

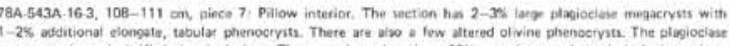

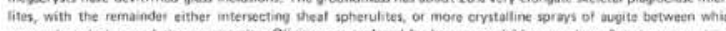

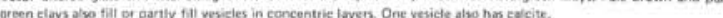

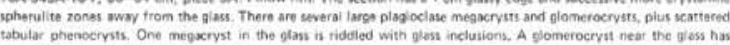

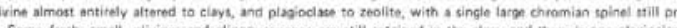

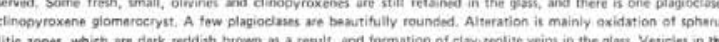

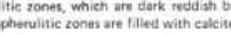




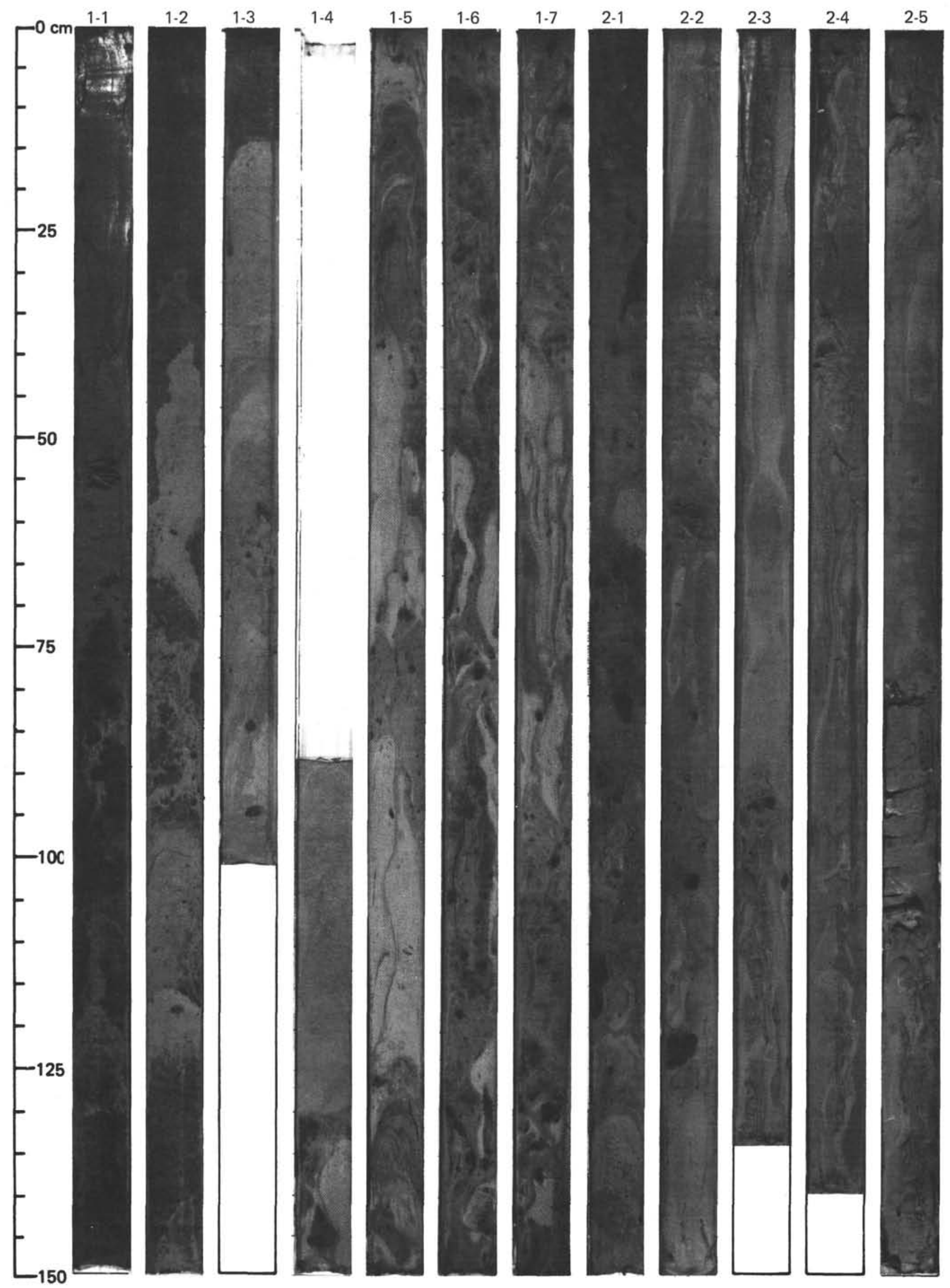




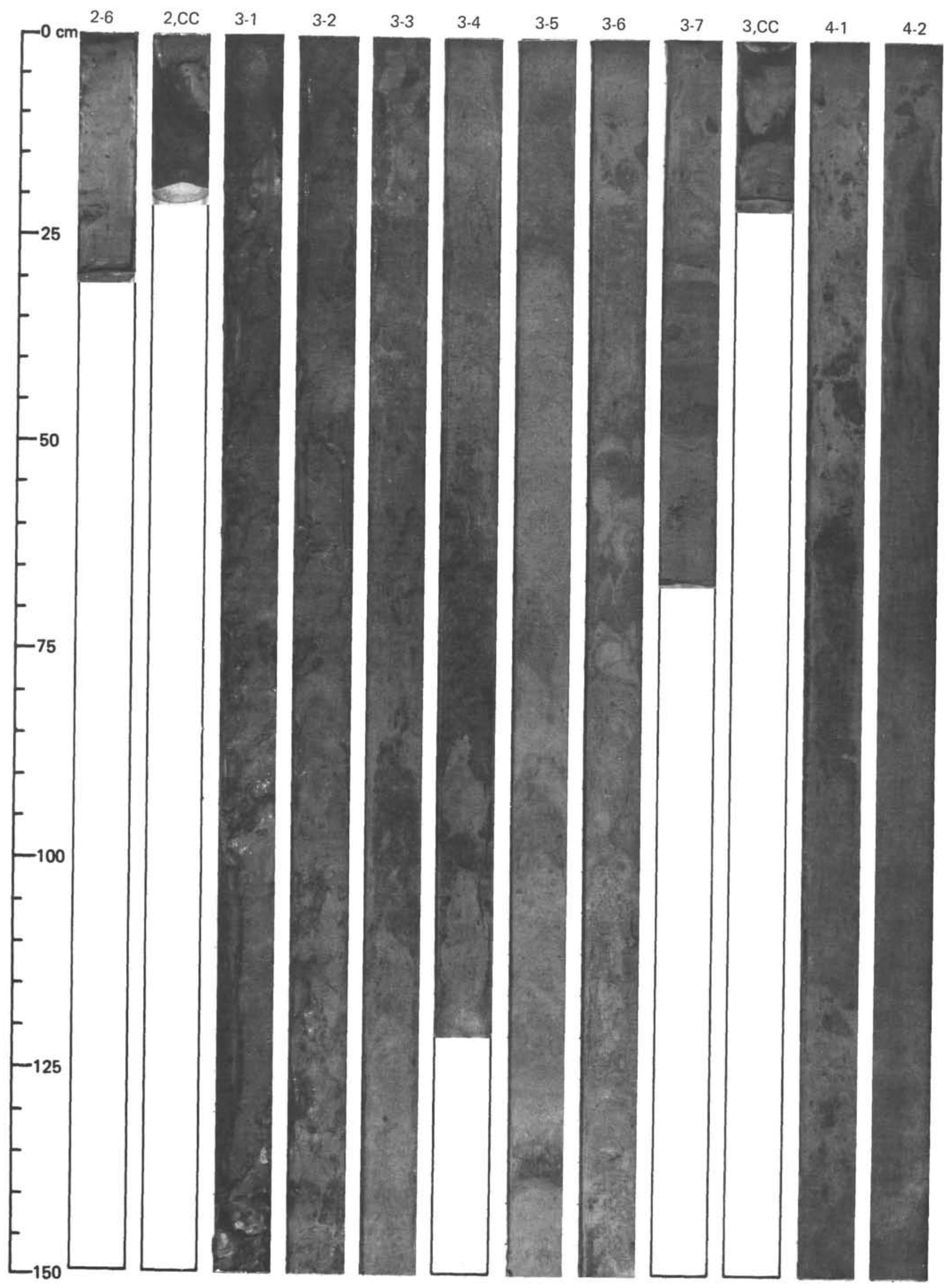




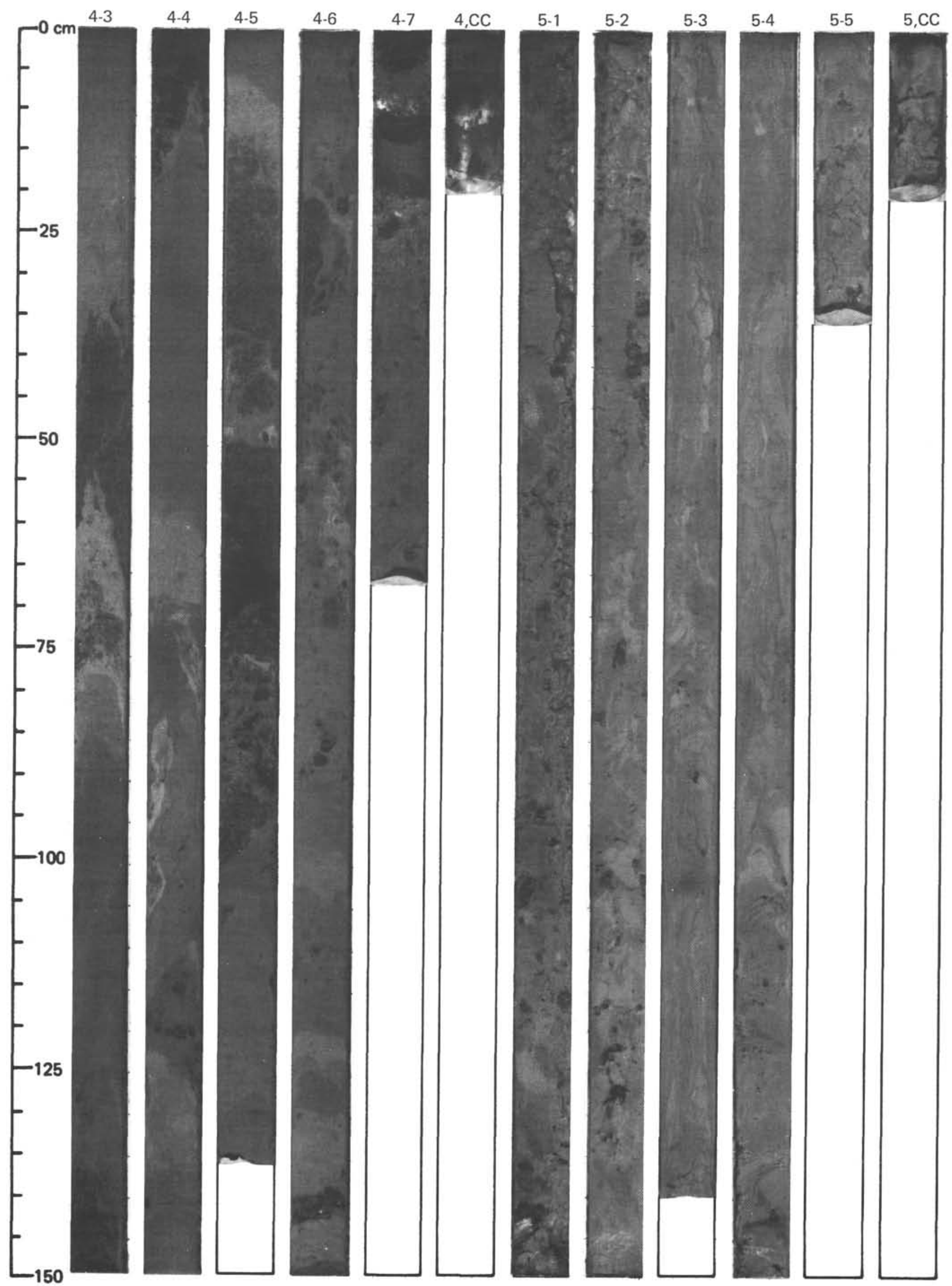




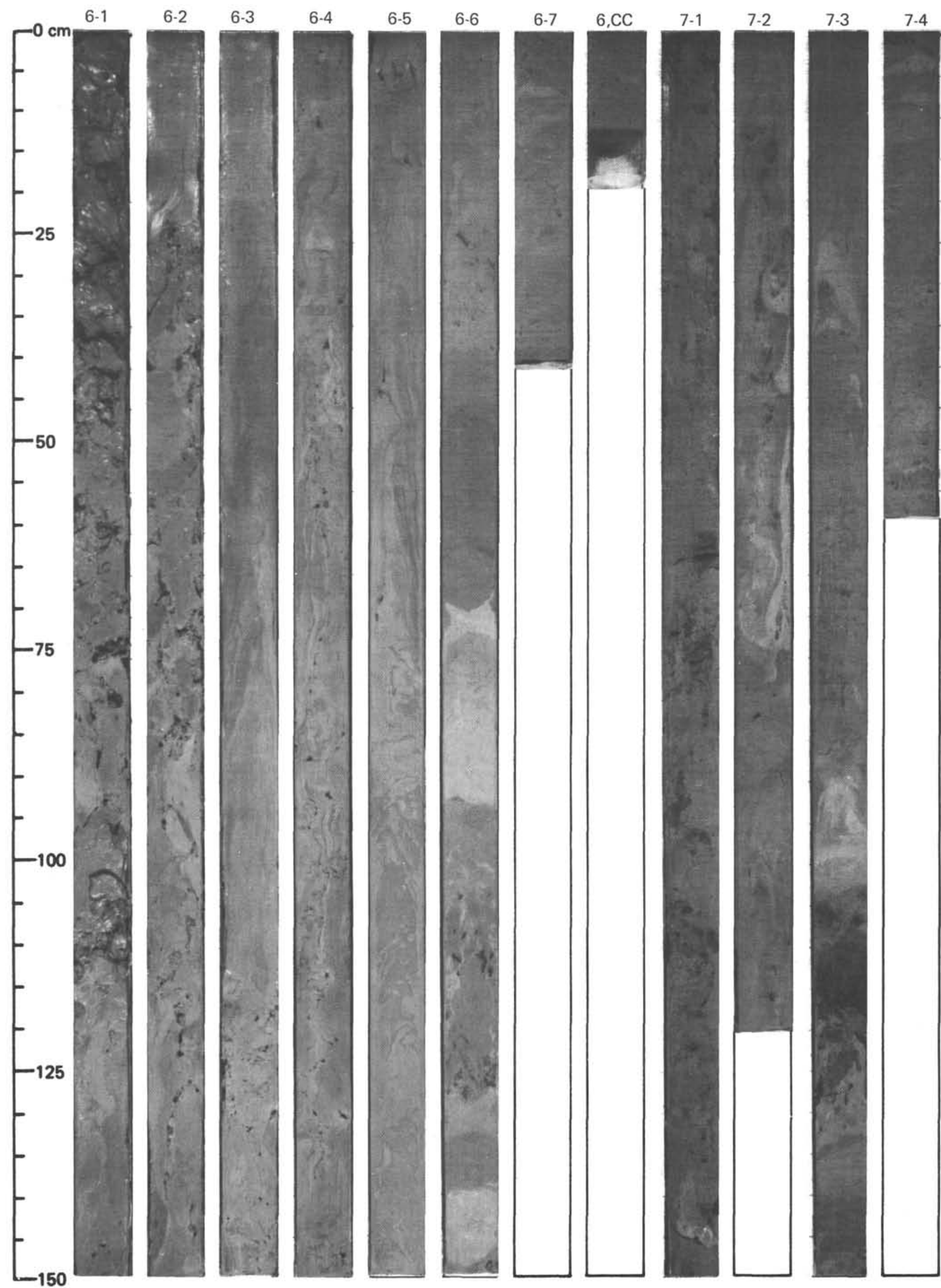




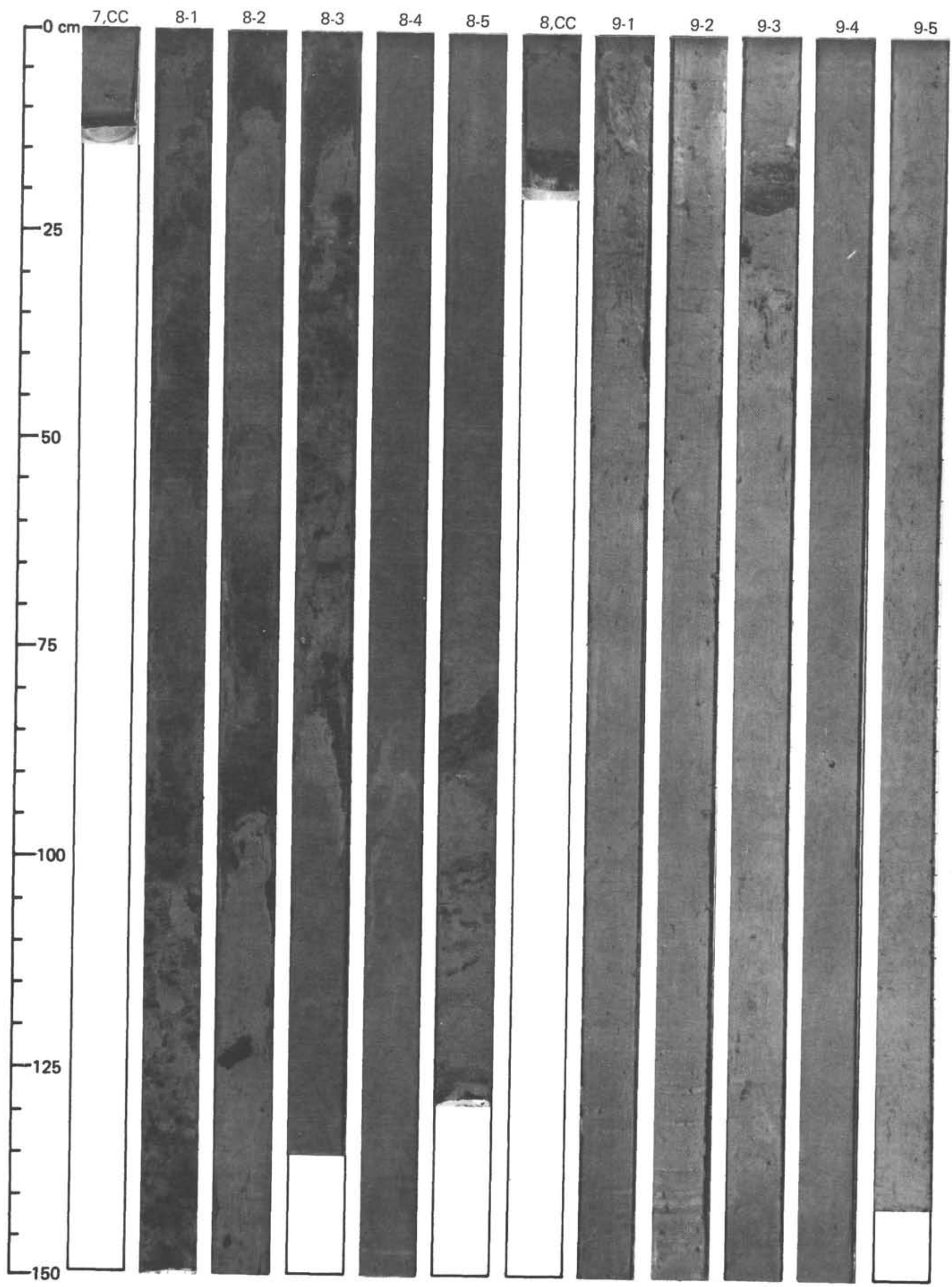




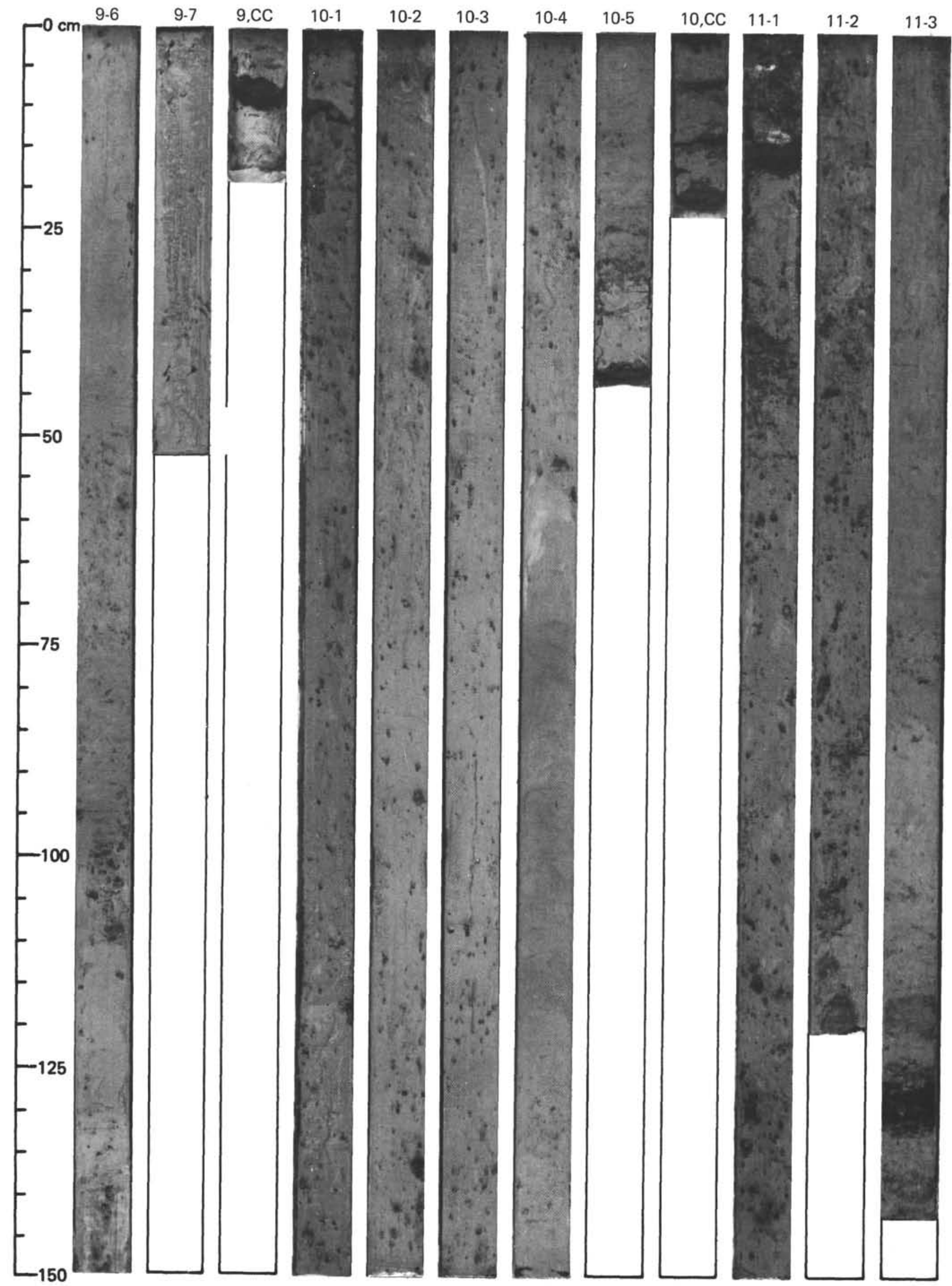




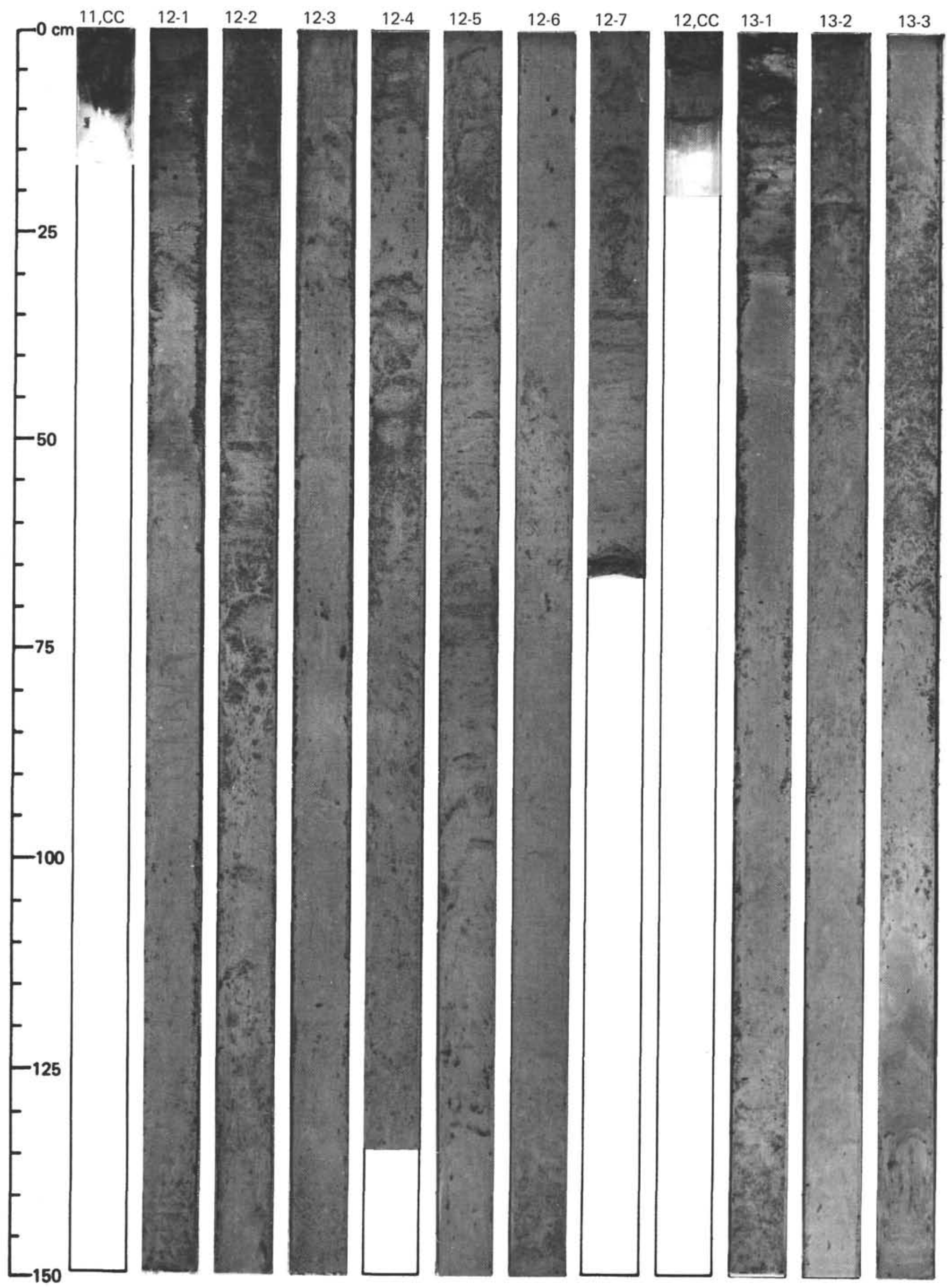




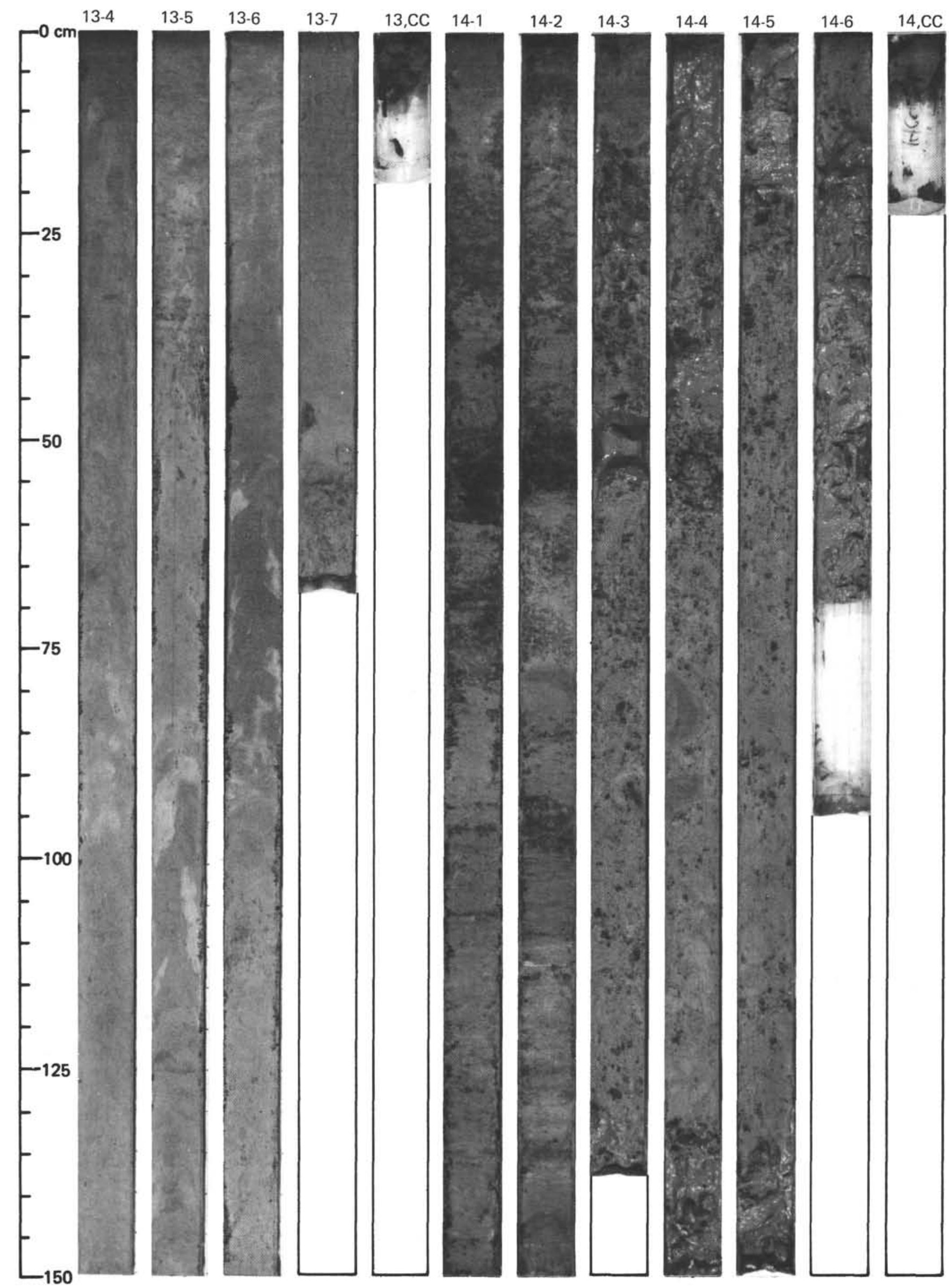




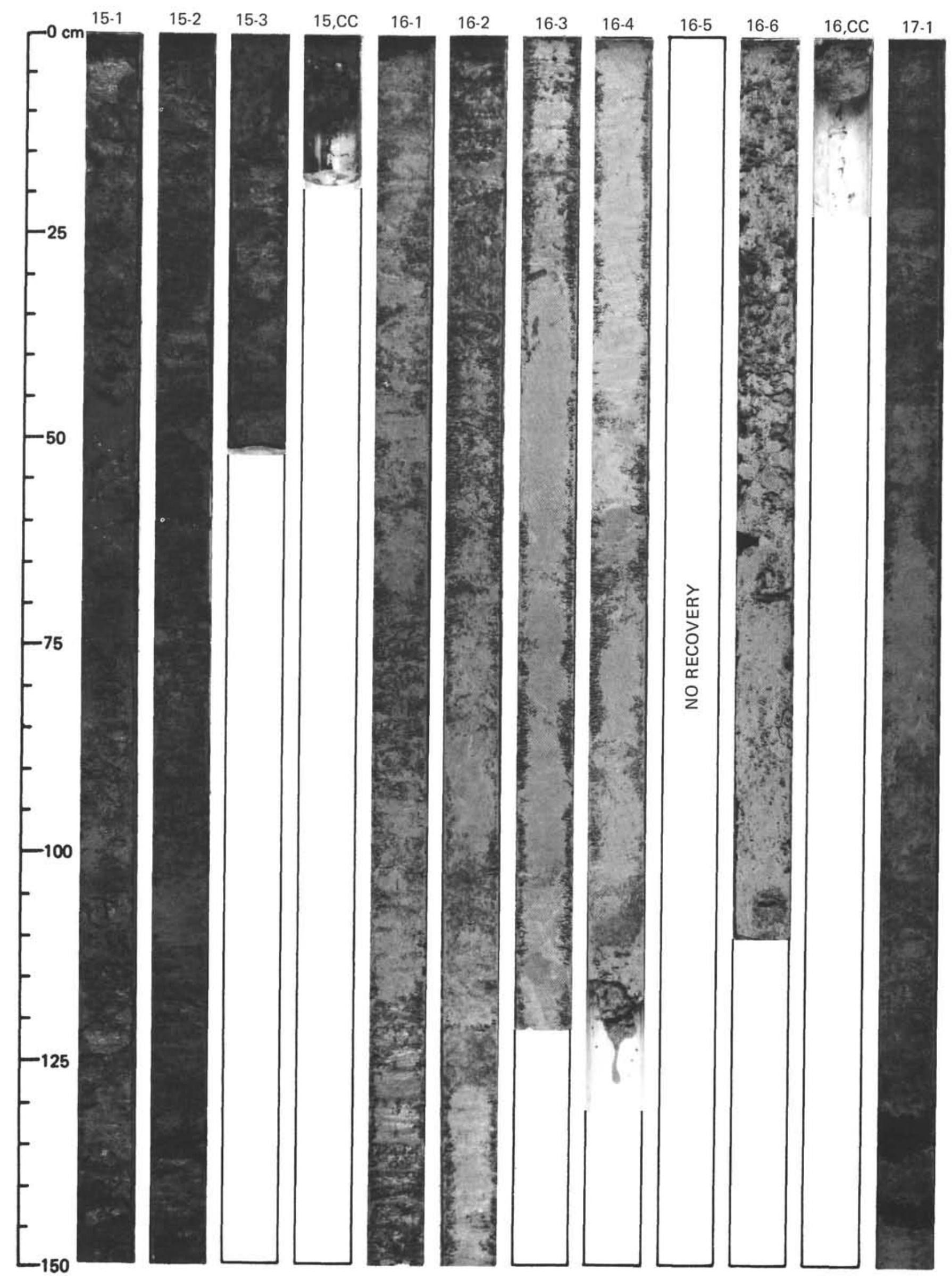




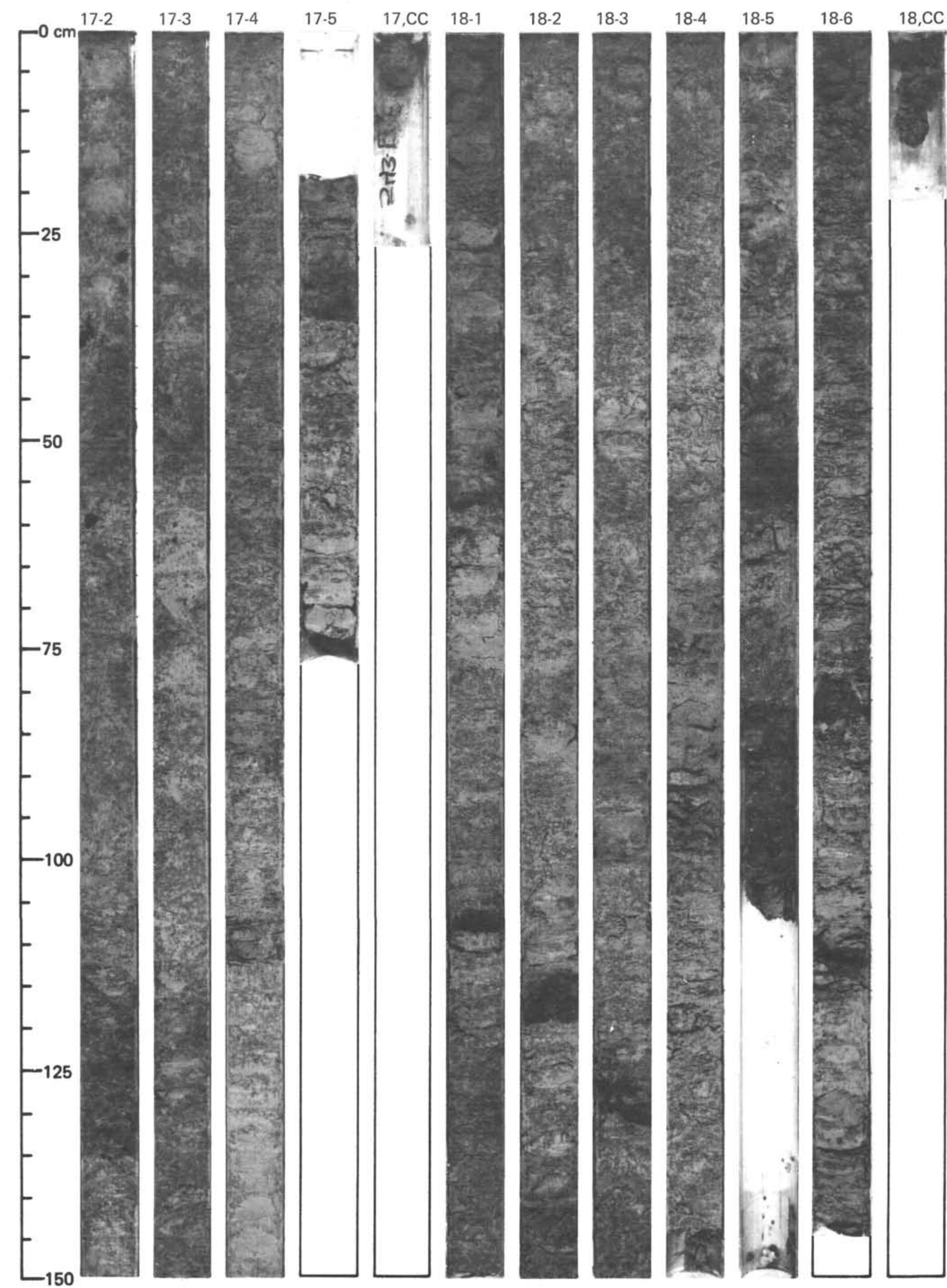




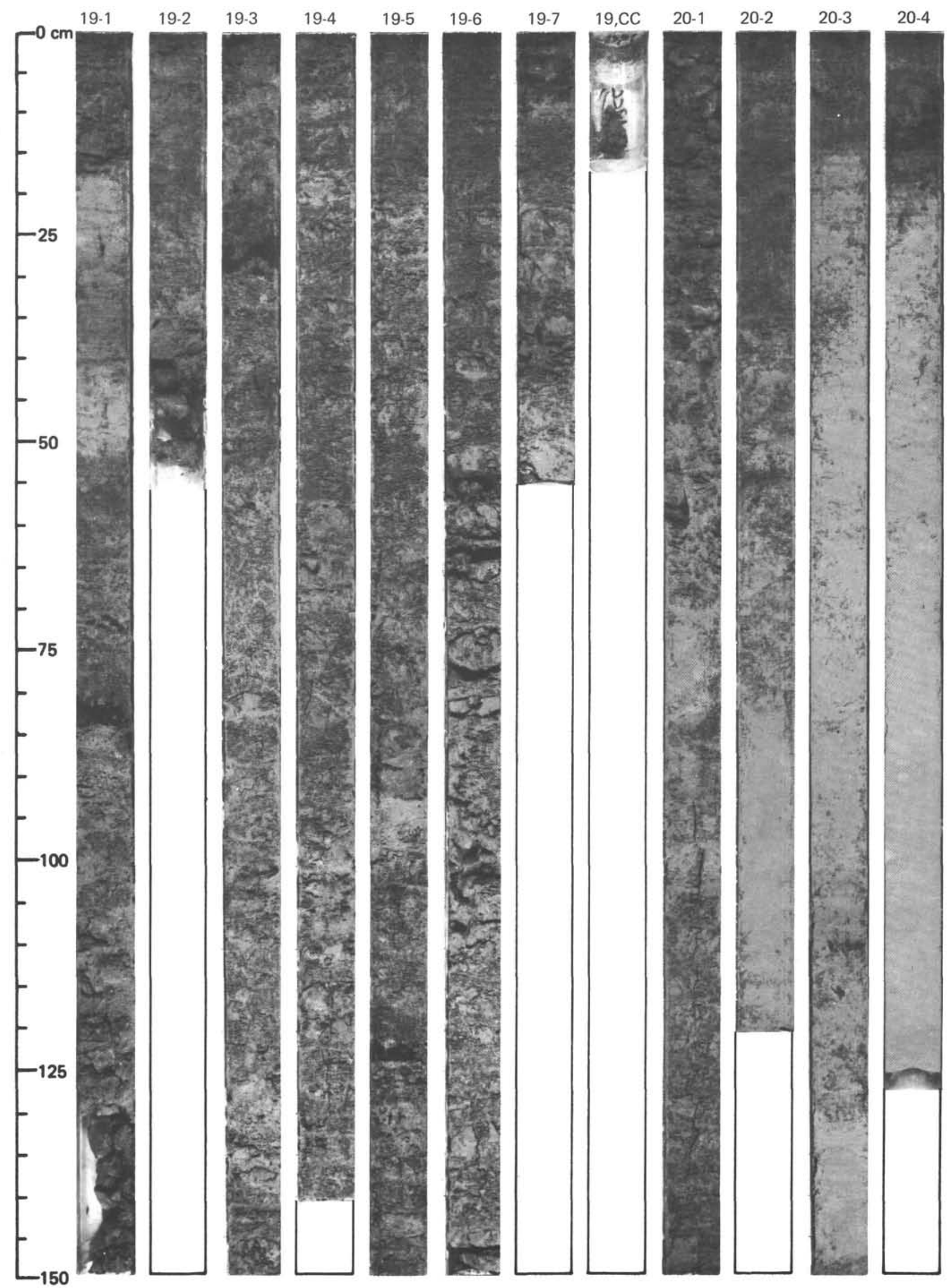


SITE 543

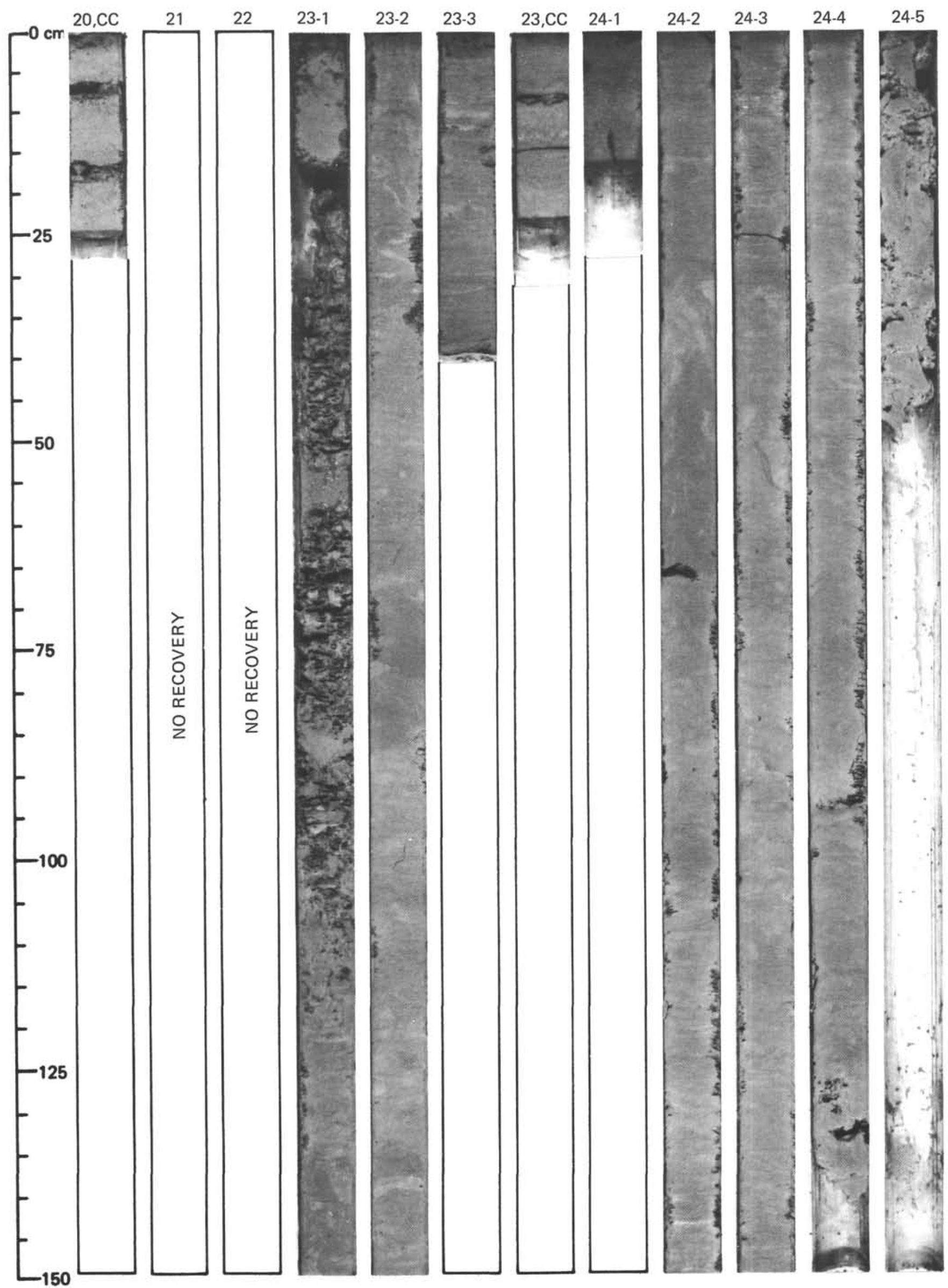




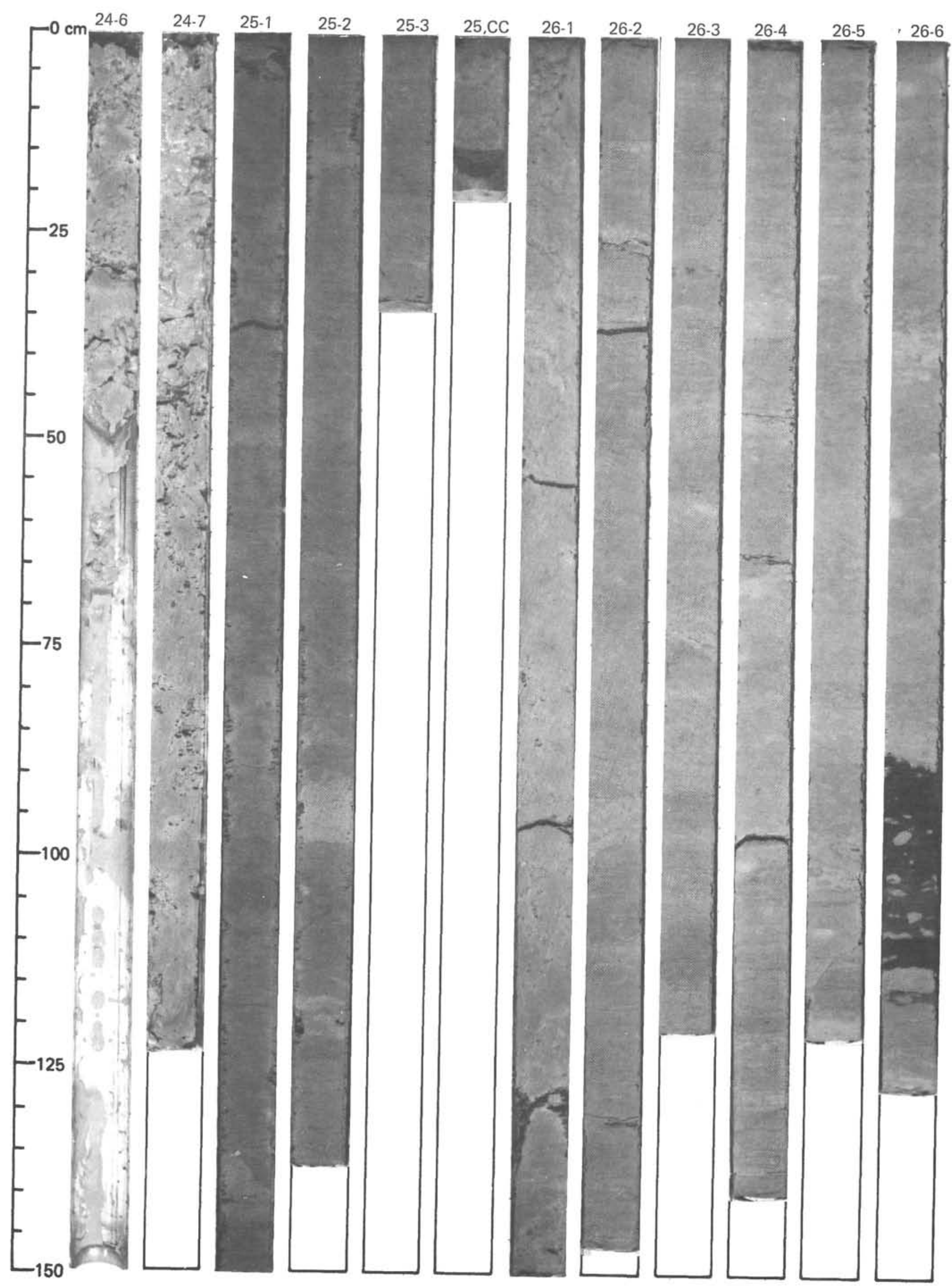




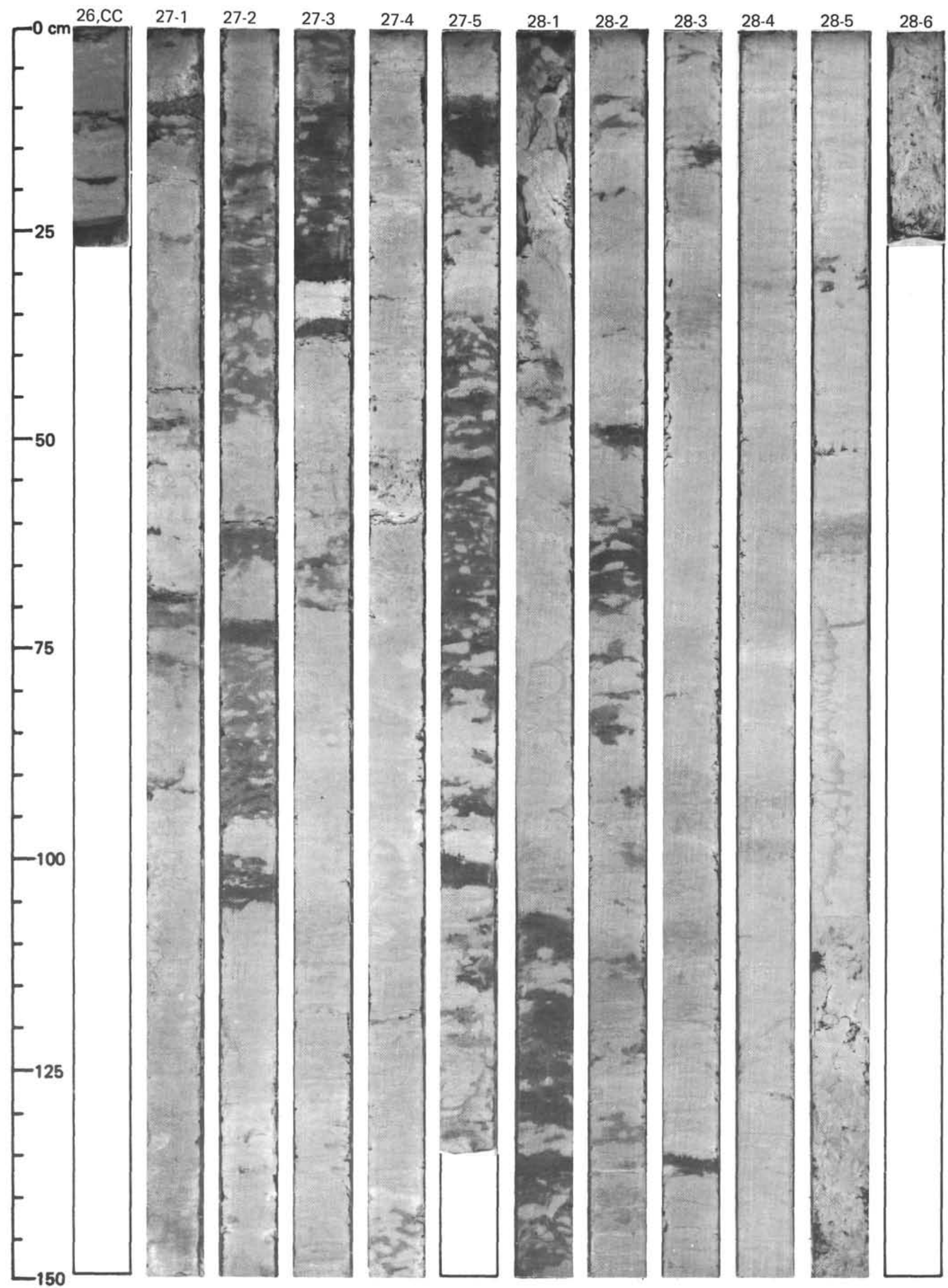




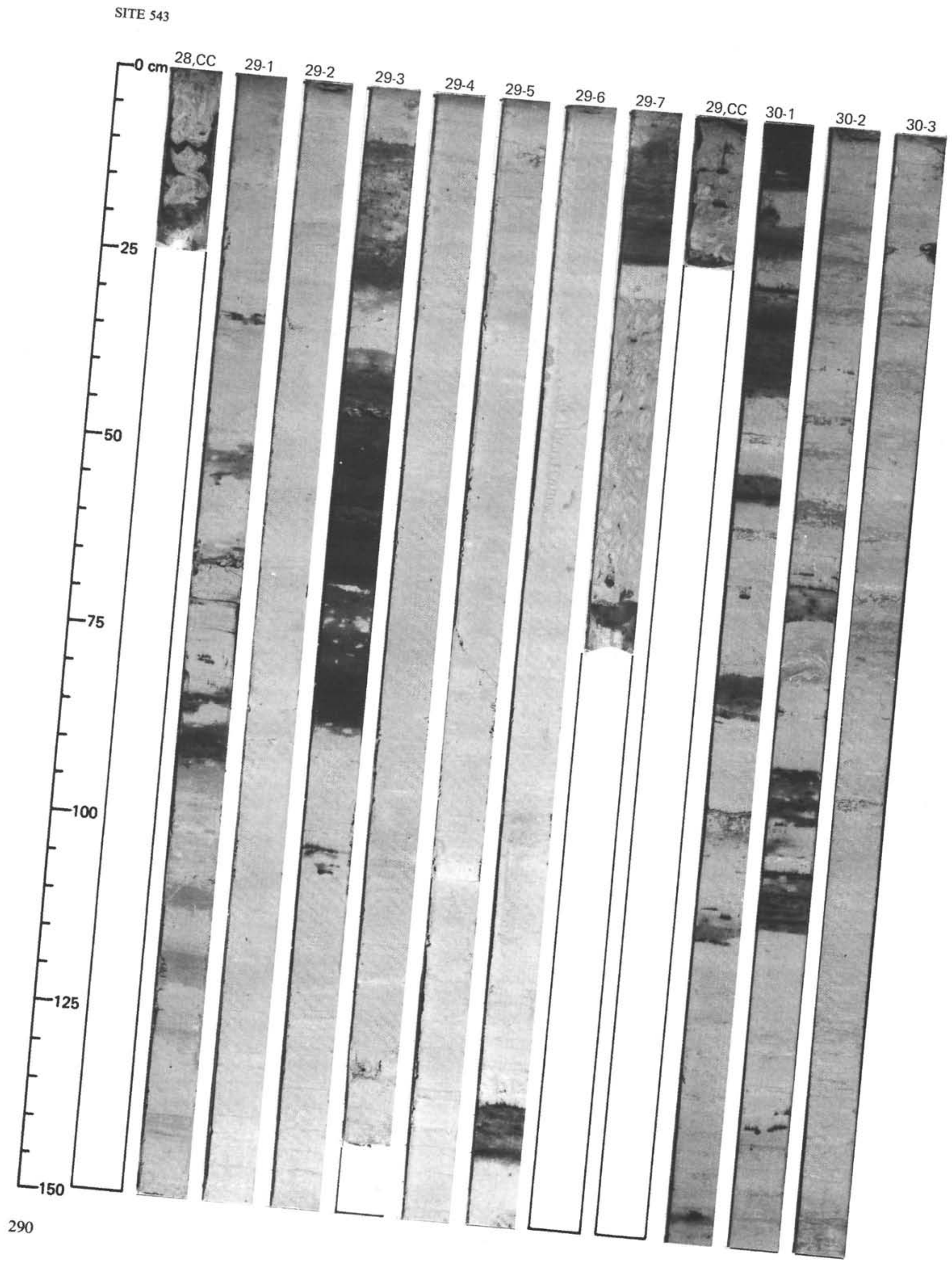




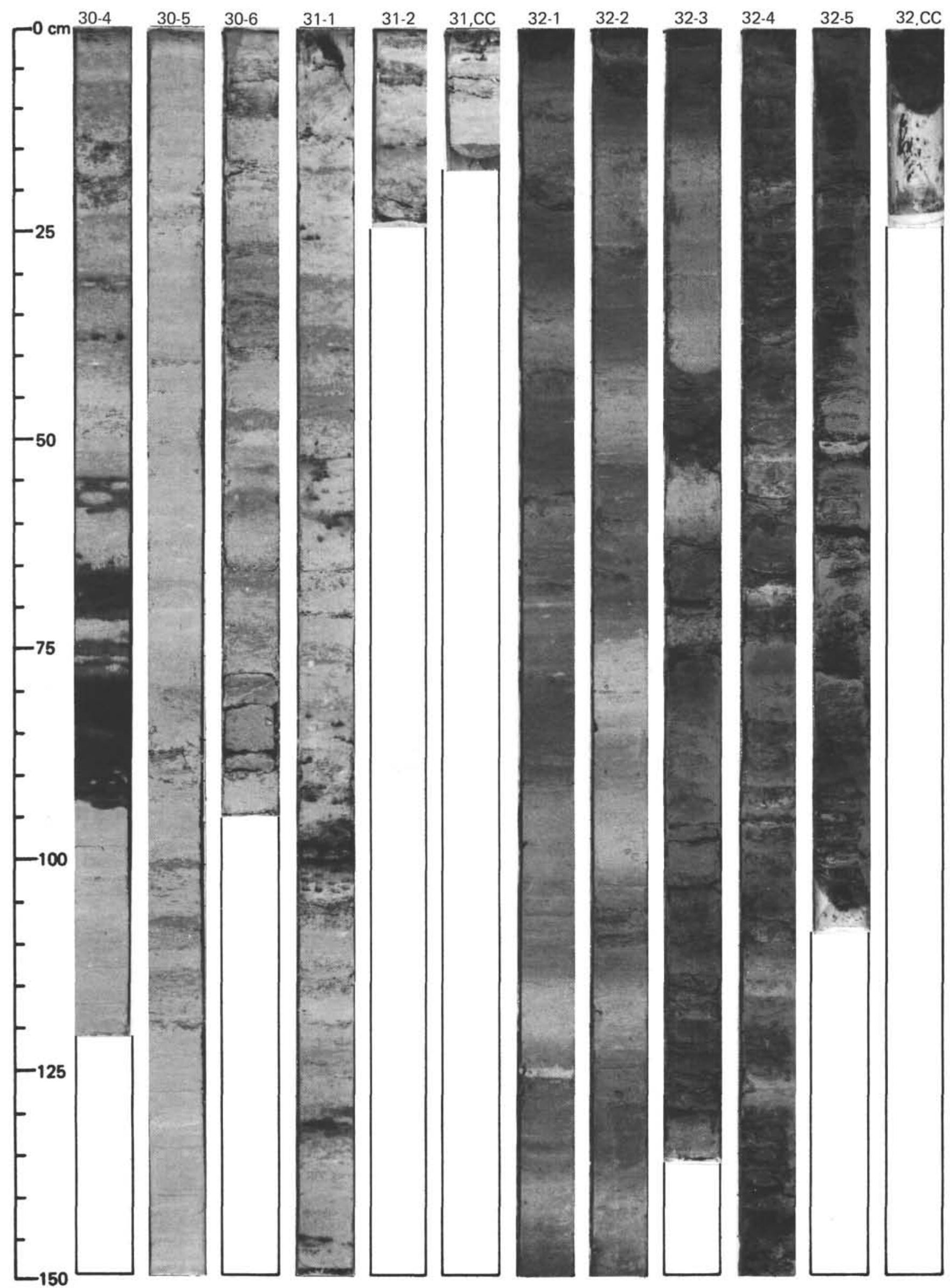


SITE 543

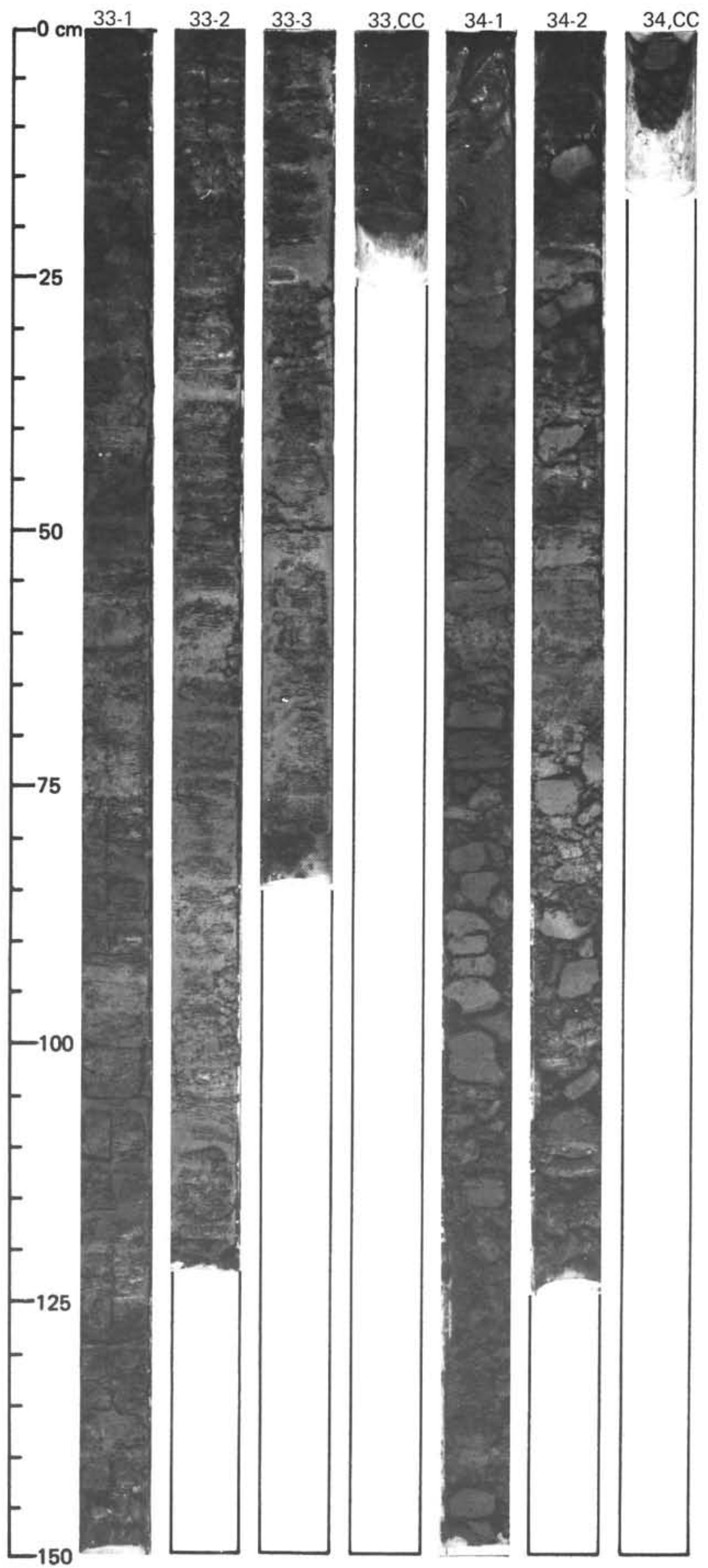




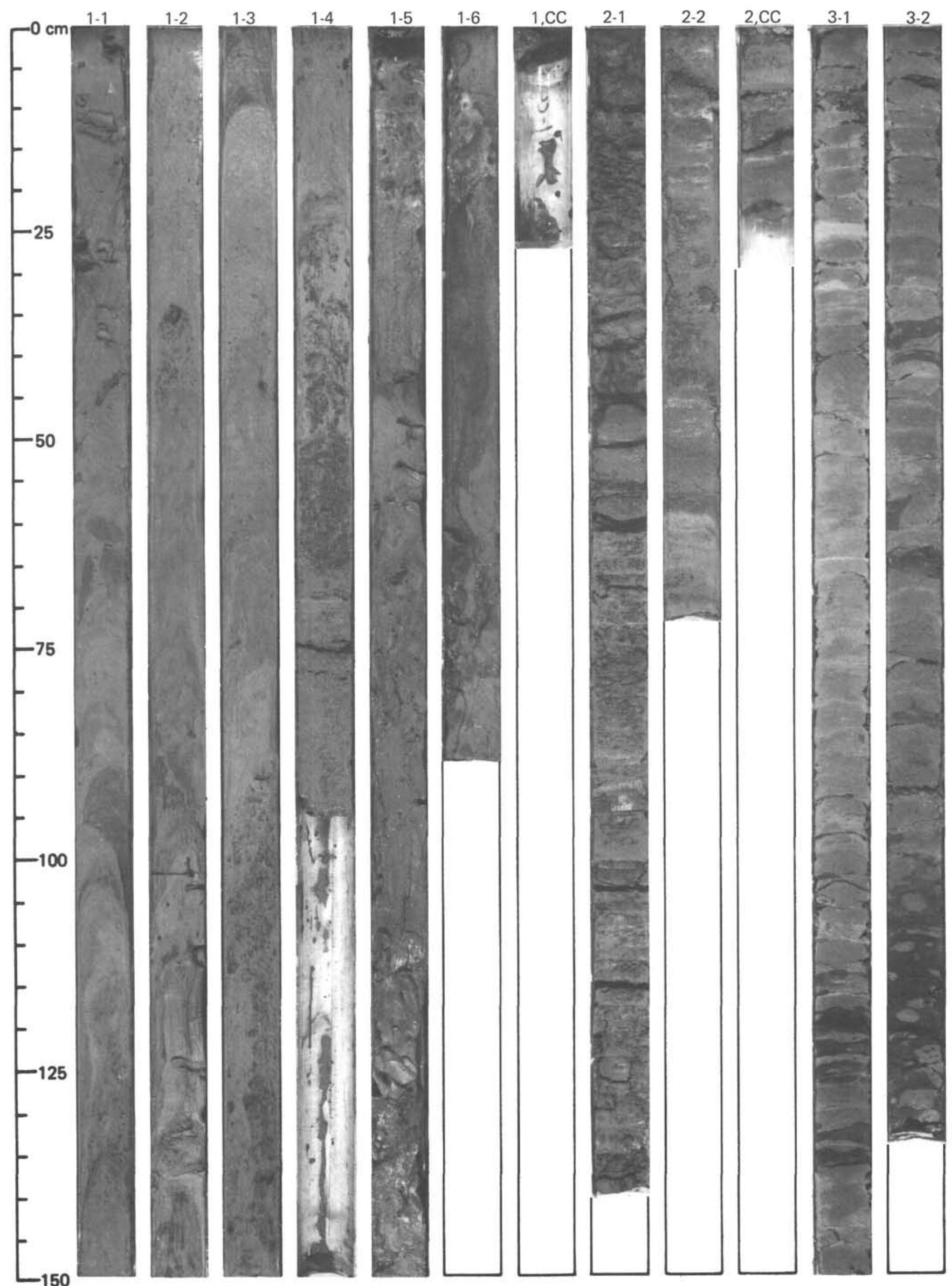




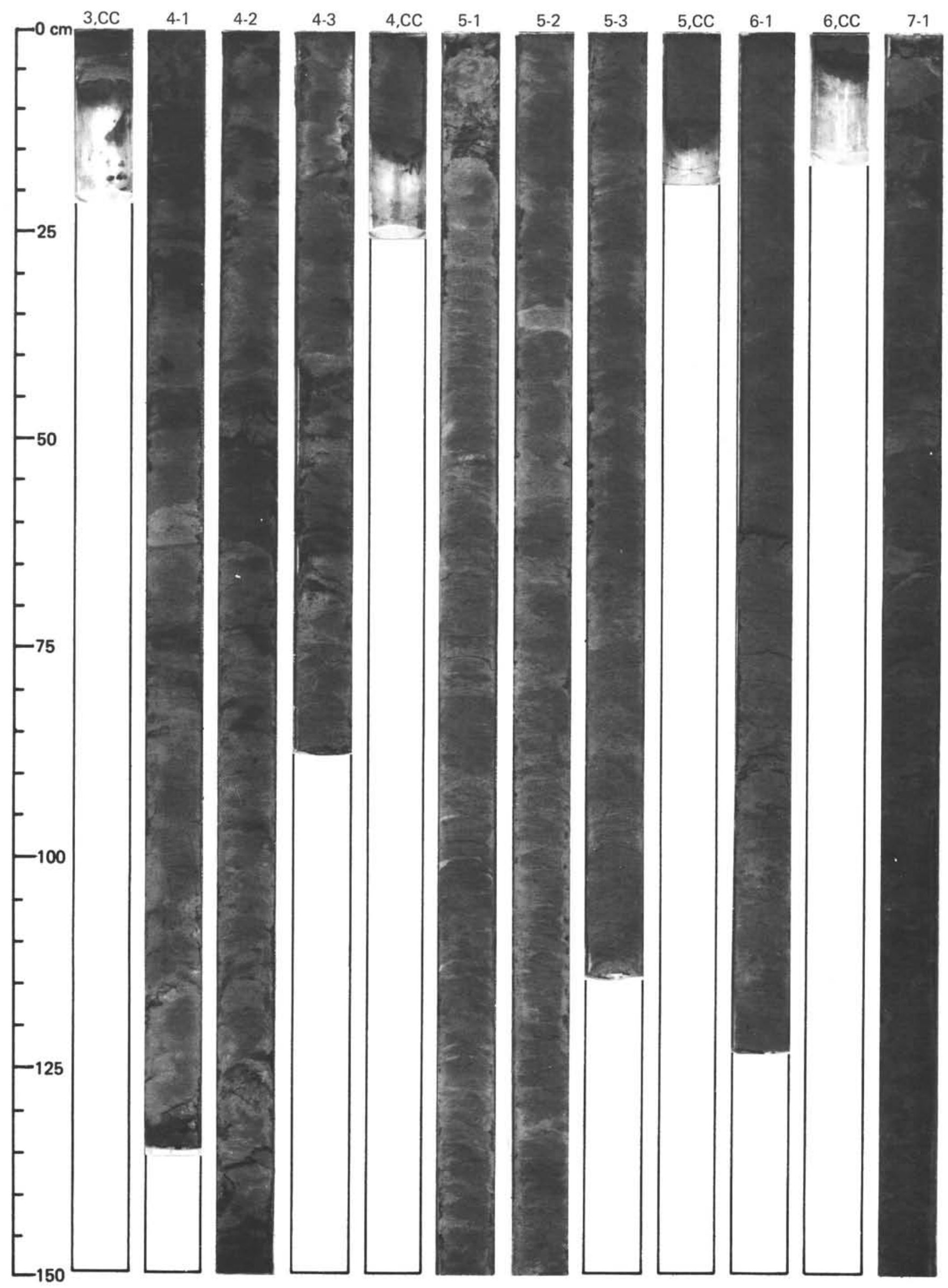




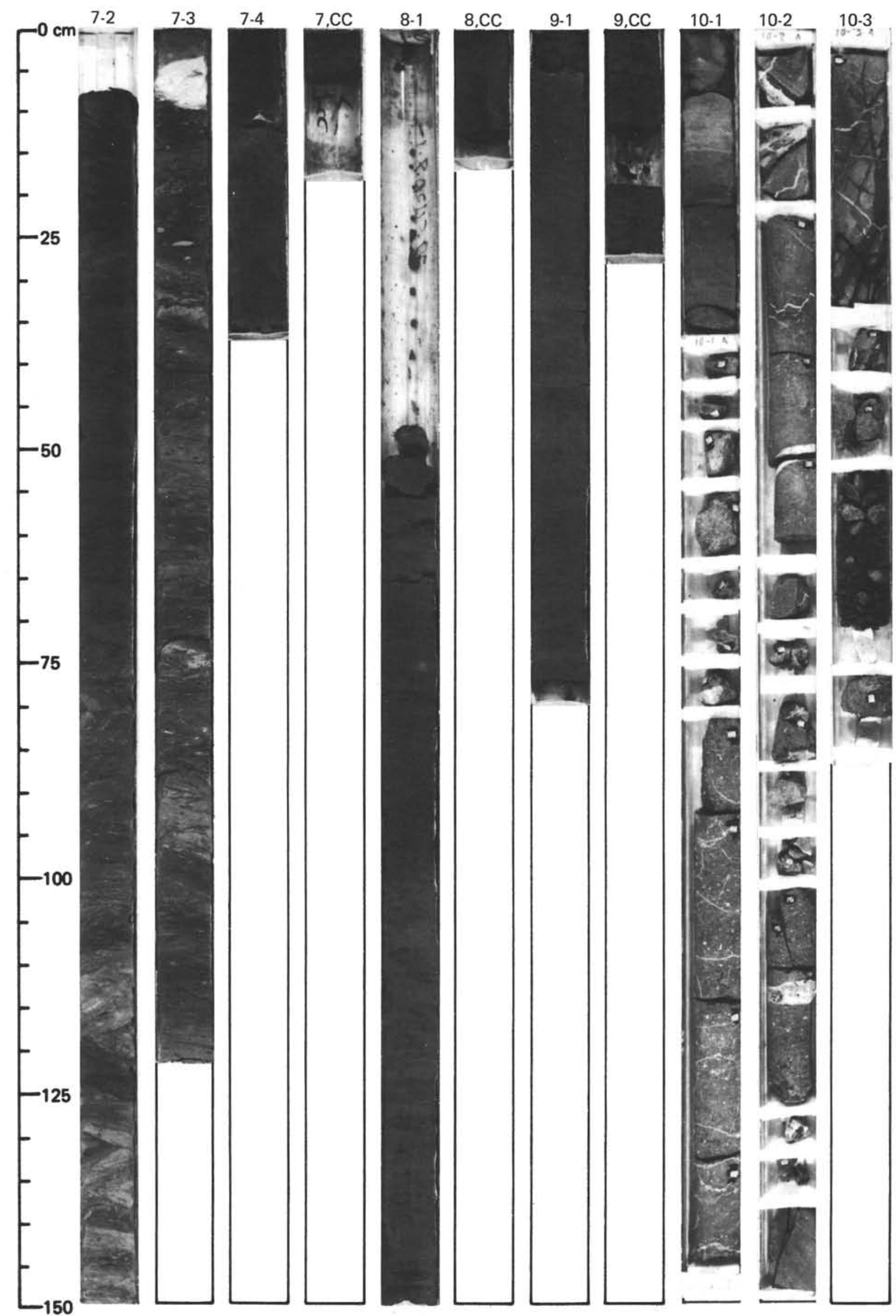




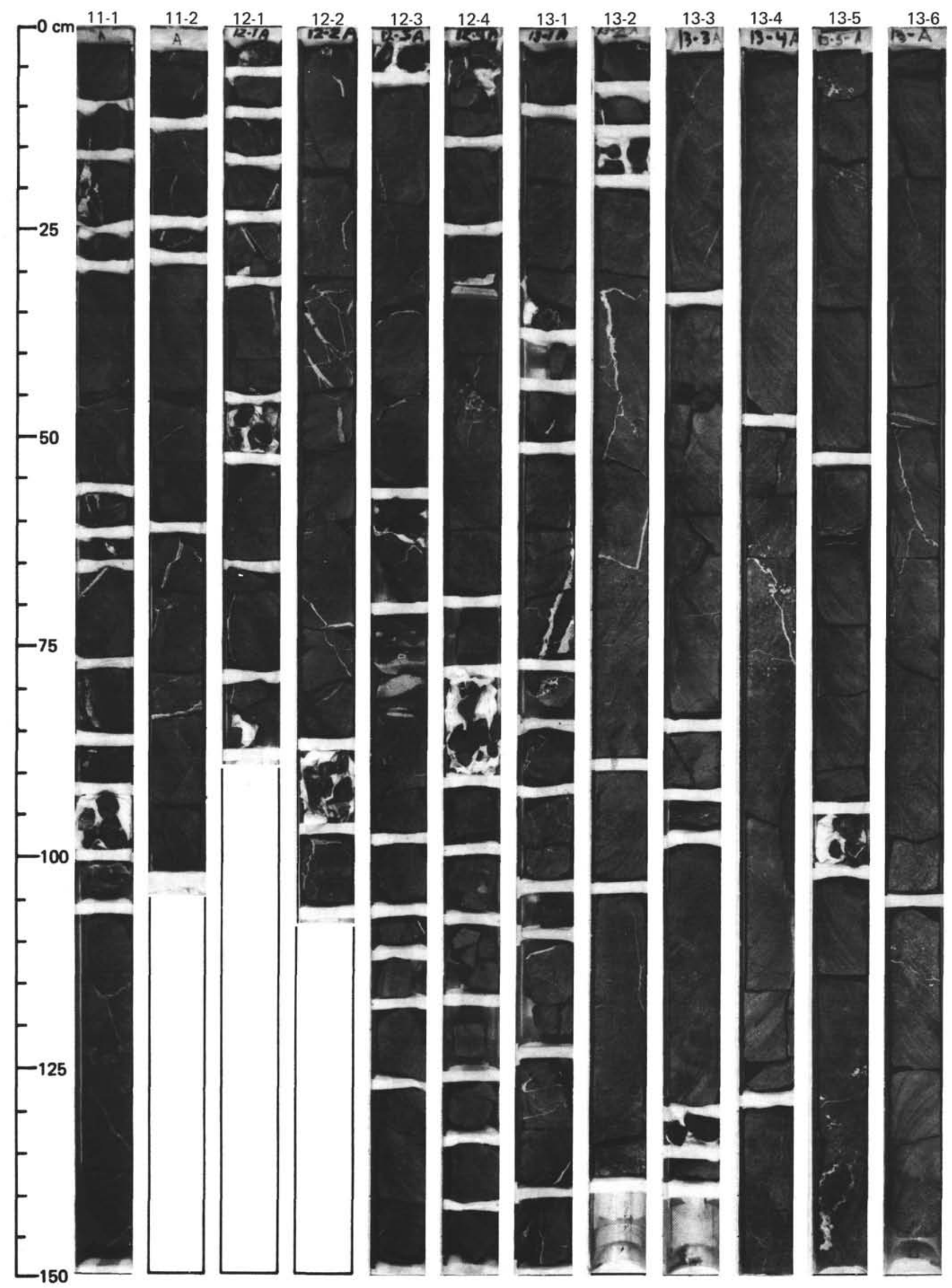




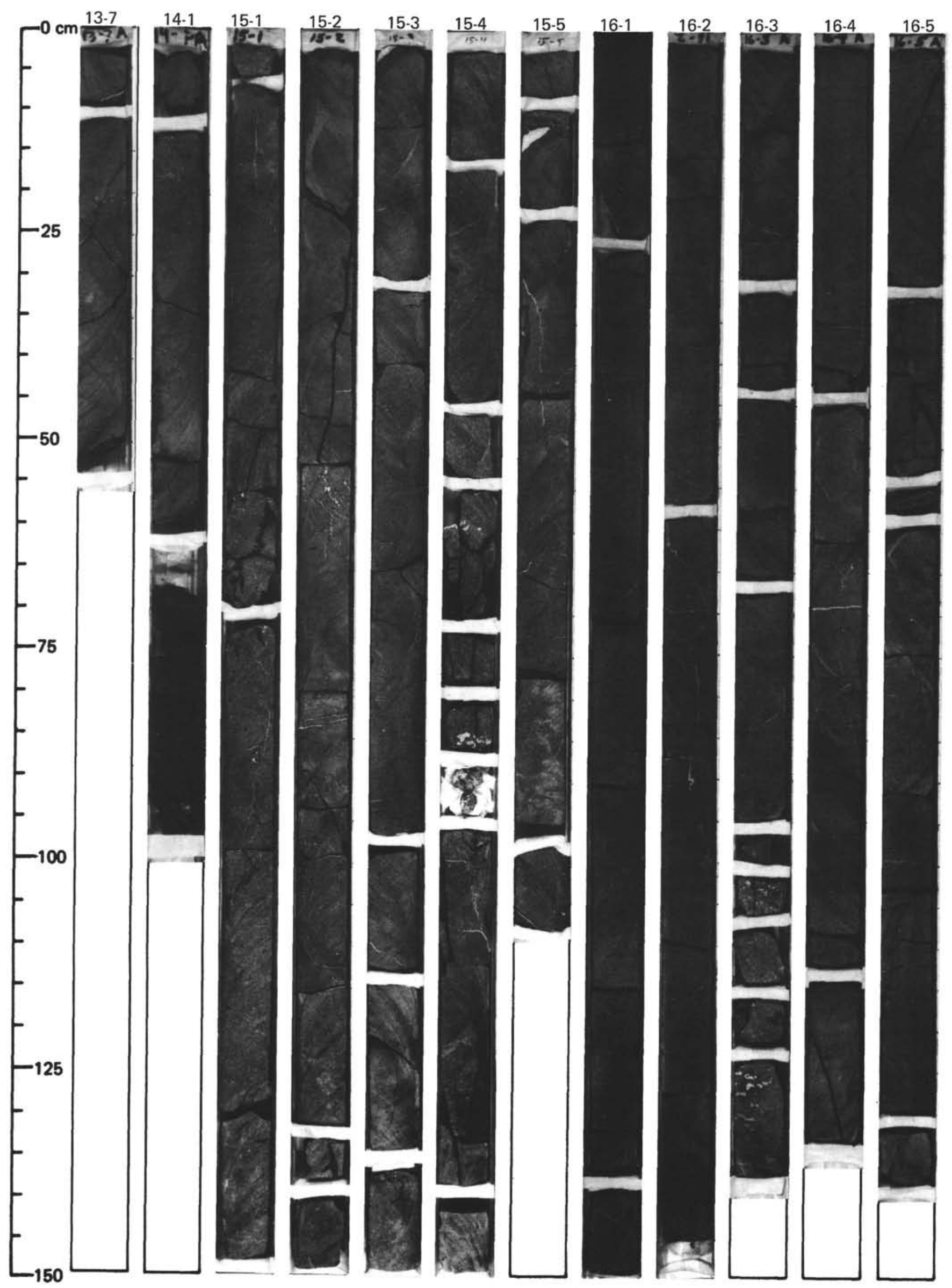


SITE 543

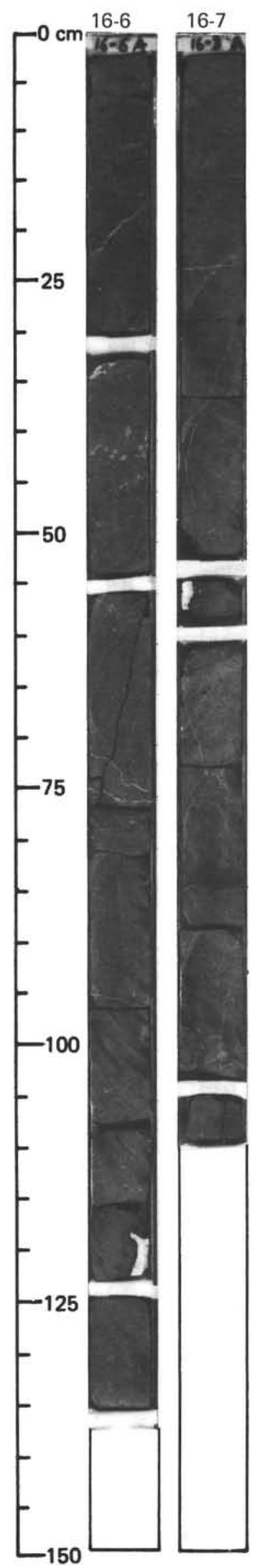

